\title{
Small cell lung cancer and brain metastasis
}

Citation for published version (APA):

van Oosterhout, A. G. M. (1995). Small cell lung cancer and brain metastasis. [Doctoral Thesis, Maastricht University]. Rijksuniversiteit Limburg. https://doi.org/10.26481/dis.19950330ao

Document status and date:

Published: 01/01/1995

DOI:

10.26481/dis.19950330ao

Document Version:

Publisher's PDF, also known as Version of record

\section{Please check the document version of this publication:}

- A submitted manuscript is the version of the article upon submission and before peer-review. There can be important differences between the submitted version and the official published version of record.

People interested in the research are advised to contact the author for the final version of the publication, or visit the DOI to the publisher's website.

- The final author version and the galley proof are versions of the publication after peer review.

- The final published version features the final layout of the paper including the volume, issue and page numbers.

Link to publication

\footnotetext{
General rights rights.

- You may freely distribute the URL identifying the publication in the public portal. please follow below link for the End User Agreement:

www.umlib.nl/taverne-license

Take down policy

If you believe that this document breaches copyright please contact us at:

repository@maastrichtuniversity.nl

providing details and we will investigate your claim.
}

Copyright and moral rights for the publications made accessible in the public portal are retained by the authors and/or other copyright owners and it is a condition of accessing publications that users recognise and abide by the legal requirements associated with these

- Users may download and print one copy of any publication from the public portal for the purpose of private study or research.

- You may not further distribute the material or use it for any profit-making activity or commercial gain

If the publication is distributed under the terms of Article $25 \mathrm{fa}$ of the Dutch Copyright Act, indicated by the "Taverne" license above, 


\section{Small cell lung cancer}

and brain metastasis 


\section{Copyright @ 1995}

Niets uit deze uitgave mag worden verveelvoudigd en / of openbaar gemaakt door middel van druk, fotokopie, microfilm of op enige andere wijze, noch opgeslagen in een retrieval-systeem noch vertaald in welke taal dan ook, zonder voorafgaande schriftelijke toestemming van de auteur.

No part of this book may be reproduced or transmitted in any form or by any means, electronic, mechanical, photocopying, recording or otherwise, withour the prior written permission from the author.

Printed and bound in the Netherlands ISBN 90-9008180-1

Druk: van Hooren, Heerlen

Vormgeving: Mady Reliëf, Landgraaf 


\section{Small cell lung cancer}

\section{and brain metastasis}

\section{Proefschrift}

ter verkrijging van de graad van doctor aan de Rijksuniversiteit Limburg te Maastricht, op gezag van de Rector Magnificus, Prof. Mr. M.J. Cohen, volgens het besluit van het College van Dekanen, in het openbaar te verdedigen op donderdag 30 maart 1995 om 16.00

door

Anselmus Gerardus Maria van Oosterhout

geboren te Delft in 1961 


\section{Promotores}

Prof. Dr. J. Troost

Prof. Dr. G. Blijham (Universiteit Utrecht)

\section{Co-promoter}

Dr. A. Twijnstra

Beoordelingscommissie

Prof. Dr. H.F.P. Hillen (voorzitter)

Prof. Dr. B.W. Ongerboer de Visser (Universiteit van Amsterdam)

Prof. Dr. J.M.A. van Engelshoven

Prof. Dr. Sj. Sc. Wagenaar

Prof. Dr. E.F.M. Wouters

From the Department of Neurology, University Hospital Maastricht, The Netherlands.

The author wishes to thank Joachim Weis, Department of Neuropathology, RWTH Aachen, Germany for providing the front cover illustration.

The publication of this thesis was financially supported by:

Ziekenhuis De Wever \& Gregorius, Integraal Kankercentrum Limburg, Glaxo BV, Sanofi Winthrop v.o.f., Katwijk farma BV, Ciba Geigy BV. 
The more you get

the more you want

-it seems.

(Ferdinand Morton in 'Doctor Jazz', 1926)

Aan mijn ouders

Voor Marianne 
The main results of this thesis are reported in the following papers:

1. van Oosterhout AGM, van de Pol M, ten Velde G, Volovics A, Twijnstra A.

Neurological disorders in 203 consecutive patients with small cell lung cancer: results of a longitudinal study. Submitted.

2. Oosterhout van AGM, Thunissen F, Volovics A, Pol van de M, Velde ten GP, Twijnstra A. The role of histopathologic subtyping in predicting neurologic complications in small cell lung cancer. International Journal of Oncology 4: 201-205, 1994.

3. Habets JM, Oosterhout van AGM, Velde ten GP, Wilmink JT, Twijnstra A. Diagnostic value of CT in the detection of brain metastases in small cell lung cancer patients. BTR 75: 179-181, 1992.

4. 'Twijnstra A, Oosterhout van AGM, Pol van de M, Wilmink JT, Velde ten GP. Diagnostic value of MR imaging in the detection of brain metastases at initial staging in small cell lung cancer. Neuroradiology (in press).

5. Oosterhour van AGM, Pol van de M, Volovics A, Velde ten GP, Twijnstra A. Efficacy and safety of prophylactic cranial irradiation in 203 consecutive patients with small cell lung cancer. Submitted.

6. Oosterhout van AGM, Boon PJ, Houx PJ, Velde ten GPM, Twijnstra A. Follow-up of cognitive functioning in patients with small cell lung cancer. Int J Radiat Oncol Biol Physs (in press).

7. Oosterhout van AGM, Ganzevles PGJ, Wilmink IT, Geus de BWJ, Vonderen van R, Twijnstra A. Cencral nervous system roxiciry in long-term survivors of small cell lung cancer. Submitted. 


\section{Contents}

1. General introduction.

2. Neurologic disorders in 203 consecutive patients with small cell lung cancer: results of a longitudinal study.

3. The role of histopathologic subtyping in predicting neurologic complications in small cell lung cancer.

4. Diagnostic value of CT in the detection of brain metastases in small cell lung cancer patients.

5. Diagnostic value of MR imaging in the detection of brain metastascs at initial staging in small ccll lung cancer.

6. Efficacy and safety of prophylactic cranial irradiation in 203 consecutive patients with small cell lung cancer.

7. Follow-up of cognitive functioning in patients with small cell lung cancer.

8. Central nervous system toxicity in long-term survivors of small cell lung cancer.

9. General discussion

10. Summary

11. Samenvatting 



\section{General introduction}


In the countries of north-western Europe, lung cancer is the most common cancer in males [1-3]. In the Netherlands, almost 8500 persons died of lung cancer in 1987 (abour 7500 men and 1000 women) and another 261 had lung cancer as secondary cause of death, according to the

Netherlands Central Bureau for Statistics [4]. Annually, lung cancer will be diagnosed presumably in about 9500 patients (8200 men and 1300 women) [4], in other words, 1 out of every 11 men will develop lung cancer before the age of 75 versus 1 out of every 60 women $[5,6]$. The world standardised incidence rates were 81.3 for men and 10.1/100000 for women, for the two most southern areas of the Dutch provence of Limburg [7].

Since 1985 the high lung cancer incidence among males has gradually declined, whereas the low incidence for females rapidly increased since 1989 [5]. At the same time, the age-adjusted incidence and the proportional distribution of histological types showed a striking increase in adenocarcinoma for males, while a decline was observed in squamous and small cell carcinoma [4]. For females the incidence of all types, including undifferentiated cancer, increased [4]. Small cell lung cancer (SCLC) accounted for $17 \%$ of all lung cancer in males and $23 \%$ in females $[4,6]$. The changes in lung cancer rates and distribution of histological types are probably related to changes in smoking behavior, as the number of male smokers declined and female smokers sharply rose $[5,6]$.
Small cell lung cancer distinguishes itself from other types of lung carcinomas by a remarkable propensity for early systemic spread and substantially greater initial sensirivity ro chemotherapy and radiotherapy [8-13]. Nearly all patients have mediastinal or systemic merastases at the time of inirial diagnosis, precluding therapy with surgery alone [1+-16].

Combination chemotherapy will result in objective response rates in 85 to $95 \%$ for limited disease and in 65 to $85 \%$ in extensive disease parients [17]. Complete responses can be produced in about $50 \%$ of limited disease and in about $25 \%$ of extensive disease parients [17].

Depending on the addition of radiocherapy, in limited disease patients about a third will have disease free survival in excess of two years. Long term disease free survival in extensive disease patients is unusual. Despite constant refinements and changes of the therapy, long term survival remained stable at a 10 to $20 \%$ at [wo years $[18,19]$ and a poor $5 \%$ at five years [20], in the last decade.

A wide array of neurologic complications, diverging from brain metastases to paraneoplastic disorders, can complicate SCLC [21-24]. Neurologic complications of SCLC are mainly metastatic in nature; about $10 \%$ of the patients have brain metastases at initial diagnosis, about $30 \%$ subsequently develop brain merastases during treatment, and at autopsy the frequency is approximately 50\% [25-27]. The actuarial risk of brain metastases increased with lengthening of survival to 
50 to $80 \%$, at two years from diagnosis [28-30]. Though the use of prophylactic cranial irradiation (PCI) effectively reduced the frequency of brain metastases [31-33], PCI became controversial as it did not provide any survival benefit and was associated with central nervous system (CNS) toxicity [34-35].

Manifestations of neurotoxicity and paraneoplastic syndromes may be confused with sympromatic CNS metastases. The pathogenesis of $\mathrm{PCl}$ related neurotoxicity is insufficiently understood as it is predominately described in small series of long rerm survivors, rreated and analysed differently $[36-50]$.

In this thesis, several aspects of brain metastasis in SCLC are investigared. The data used for most scudies were yielded by a SCLC case register program, which began in October 1980. As part of this program patients with SCLC were seen by a neurologist at diagnosis and regular intervals thereafter. A CT-scan of the brain, MR-scan after 1991, was routinely performed at inirial staging. More frequent neurologic consultations and other diagnostic tests were performed if required. Long term survivors werc cxamined in different hospical troughout the Netherlands by a neurologist and neuropsychologist. The goals of the study thesis were:

- to describe the resules of a neurologic follow-up of 203 consecutive patients with SCLC (chapter 1);

- to study the value of histopathologic subtyping of SCLC in predicting neurolo- gic complications (chapter 2);

- to investigate the value of C'T-scan (chapter 3) and MRI (chapter 4) for the derection of brain metastases, in context to the inirial staging procedure;

- to describe the efficacy and safety of $\mathrm{PCI}$ in 203 consecutive patients with SCLC (chapter 5);

- to prospectively study the cognitive functioning of 32 consecurive patients with SCLC (chapter 6);

- to recrospectively investigate the neurologic outcome of 59 long-term survivors of SCLC (chapter 7).

Neurologic disorders are a fruquent and enthralling problem in patients with SCLC. Some clinical aspects of brain metastasis in SCLC and its treatment are highlighted in this thesis. 


\section{References}

1. Parkin DM, Whelan S, eds. Patterns of Cancer in Five Concinents. Volume VI. Lyon: IARC Scientific Publicatiions Nr 120, 1990.

2. Moller Jensen O, Estève J, Moller H, Renard H. Cancer in the Europeanb Community and its member stares. Eur J Cancer 1990; 26: 1167-1256.

3. Arlas of cancer mortalityin Europe, 1979-88. Lyon: IARC Scientific Publicatiions Nr 105, 1991.

4. Coebergh JWW, Schipper RM, Wagenaar SjSc. Epidemiology of lung cancer in the Netherlands: trends in incidence, patterns of eare and survival in sourheastern Necherlands in the period 1957-87. In: Diagnostiek Longkanker. Urrecht: CBO, 1990: pp 313.

5. Incidence of cancer in the Nerherlands 1991. Third report of the Netherlands cancer registry. Utrecht: LOK, 1991.

\section{Heijnen MLG, Coebergh JWW, Nab HW, Rek J} van, Heijden LH van der. Incidentie van longkanker en rookgewoonten in Zuidoosi-Nederland sinds 1960; Trends en geografische verschillen. T Soc Gez 1994; $72:$ 194-7.

7. Incidencic van kanker in Midden- en ZuidLimburg. Regionale Kankerregistratic IKL. Maastricht, oktober 1992. L.J. Schouten, P.A. van den Brandi en J.J. Jager.

8. Bunn PA Jr, Cohen MH, Fossieck BE Jr, Matchews MJ, Munia JP. Advances in small cell bronchogenic carcinoma. Cancer Trear Rep 6: 333342. 1977.

9. Greco FA, Einhorn LH, Richardson RL, et al. Smal cel lung cancer: Progres and perspectives. Semin Oncol 5: 523-535, 1978.

10. Weiss RB. Small cell carcinoma of the lung: Therapeutic management. Ann Intern Med 88: 522 531. 1978.
11. Aisner J, Alberto P, Bihan J, et al. Role of chemotherapy in small cell lung cancer: A concensus report of the International Associarion for the Study of Lung Cancer. Cancer Treat Rep 67: 37-43, 1983.

12. Green MR. Phase iil chemorherapy trials in small cell lung cancer. Lung Cancer 5: 17-186, 1989.

13. Hansen HH, Kristjansen PEG. Chemotherapy of small cell lung cancer. Eur J Cancer 27: 342-349, 1991.

14. Miller AB, Fox W, Tall R. Five year follow-up of the Medical Research Councel compararive trial of surgery and radiotherapy for the primary treatment of small-celled or oat-celled carcinoma of the bronchus.

15. Hansen HH, Selawry OS, Simon R, et al. Combination chemotherapy of advanced lung cancer: A randomised trial. Cancer 38: 2201-2207, 1976.

16. Osterlind $K$, Ihde DC, Etringer DS, et al. Staging and prognostic factors in small cell carcinoma of the lung. Cancer Trear Rep 67: 3-9. 1983.

17. Smit EF, Posrmus PE. Chemorherapy of small cell lung cancer.

18. Einhorn LH, Bond WH, Hombach N, Joe BT. Long-term results in combined modality treatment of small cell carcinoma of the lung. Semin Oncol 5: 309-313, 1978.

19. Hansen M. Hansen HII, Dombernowsky P. Long-term suvival in small cell carcinoma of the lung. JAMA 244: 247-250, 1980.

20. Warkin SW. Temporal demografic and epidemiologic variation in histologic types of lung cancer: a literarture review. Lung cancer 1989: 5; 69-81.

21. Scullier JP, Feld R, Evans WK, DeBoer G, Shepherd FA, Pavne DG. Pringle JF, Yeoh JL, Quirr IC, Curtis JE, Myers R, Herman JG. Neurologic disorders in patients with small cell lung cancer. Cancer 60: 2275-2283, 1987. 
22. Volk SA, Mansour RF, Gandara DR, Redmond J III. Morbidicy in long-term survivors of small cell carcinoma of the lung. Cancer 54: 25-27, 1984.

\section{Anderson NE, Cunningham J, Posner JB.}

Autoimmune parhogenesis of paraneoplastic neurologic syndromes. In: Roses A, ed. Critical review in clinical neurobiology, vol.3. Boca Raton, FL: CRC Press, 1987: 245-299.

24. Newsom-Davis J. Lambert-Eaton myststhenic syndrome. Springer Semin Immunoparhol 8: 129 $140,1985$.

25. Pedersen AG. Diagnosis of CNS merastases from SCLC. In: Lung cancer: Basic and clinical aspects. Boston, MA, Martinus Nijhoff, 1968, pp 153-182.

\section{Hirsch FR, Hansen HH, Paulson OB. Central} nervous system mecastases in small cell lung cancer. In; Ongeboer de Visser BW, Bosch DA, WoerkomEykenboom WMH, eds. Neuro-Oncology clinical and experimental aspects: Developments in oncology, 3. Hague, Martinus Nijhoff, 1980,pp 140-166.

\section{Bunn PA Jr, Nugent JL, Matthews MJ. Central} nervous system metastases in small cell bronchogenic carcinoma, Semin Oncol 5: 314-322, 1978.

28. Nugent JL, Bunn PA Jr, Matehews MJ, et al. Cencral nerous system metastases in small cell bronchogenic carcinoma. Cancer 44: 1885-1893. 1979.

29. Maurer LH, Tulloh M, Weiss RB, et al. A randomised combined modality trial in small cell carcinoma of the lung: Comparison of combination chemotherapy-radiation therapy versus cyelophosphamideradiation therapy effecrs of maintenance chemotherapy and prophylactic whole brain irradiation. Cancer 45: 30-39, 1980.

\section{Komaki R, Cox JD, Whitson W. Risk of brain} mecastasis from small cell carcinoma of the lung rela. ted to length of survival and prophylactic iradiation. Cancer Trear Rep 65: 811-814, 1981.
31. Hansen HH. Should initial trearment of smal] cell carcinoma include systemic chemotheray and brain irradiation? Cancer Chemotherapy Rep. 1973; 4: $239-241$

32. Rosen ST, Makuch RW, Aichter AS, thde DC, Matrhews MJ, Minna JD, Glarstein E, Bunn PA Jr. Role of prophylactic cranial irradiation in small cell lang cancer. Am J Med 74: 615-624, 1983.

\section{Pedersen AG, Kristjansen PEG, Hansen $\mathrm{HH}$.} Prophylacric cranial irradiation and small cell lung cancer. Cancer Trearment Reviews 1988; 15: 85-103

34. Turrisi AT. Brain irradiation and chemorherapy for small-cell lung cancer: dangerous liaisons? J Clin Oncol 8: 196-199, 1990

35. Ihde DC. Prophylactic cranial irradiarion: current controversies, Lung Cancer 9 Suppl 1: $869-574$, 1993.

36. Walker RW, Lazar RM, Gralla RJ, Scher HI, Shank B. Neuropsychological abnormalities in long: rerm survivors of small cell lung receiving prophylactic cranial irradiation. Proccedings ASCO 4: C732, 1985.

37. Licciardello, Cersosimo RJ, et al. Disturbing Central Nervous System Complications Following Combinarion Chemorherapy and Prophylacric Whole-brain Irradiation in Parients with Small Cell Lung Cancer. Cancer Treat Rep 69: 1429-1430, 1985

38. Catane R, Schwade JG. Yaar I, et al. Follow-up neurological evaluation in parients with small lung carcinoma treated wich prophylactic cranial irradiation and chemotherapy. Int J Radiat Oncol Biol Phys 7: 105-109, 1981

39. Graig JB, Jackson DV, et al. Prospective Evaluation of Changes in Computed Cranial Tomography in Parients wirh Simall Cell Lung Carcinoma Treated with Chemotherapy and Prophylactic Cranial Irradiation. J Clinic Oncol 2: 1151-1156, 1984 
40. Frytak S, Earnest IV F, O'Neill BP, Lee RE, Creagan ET, Trautmann JC. Magnetic resonance imaging for neurotoxicity oin long-term survivors of carcinoma. Mayo Clin Proc 60: 803-812, 1985.

\section{Johnson BE, Becker B, Goff WB, Petronas N, et} al. Neurologic, neuropsychologic, and computed cranial tomographic scan abnormalities in 2- to 10-year survivors of small-cell lung cancer. ] Clin Oncol 3: $1659-67,1985$

42. Chak LY, Zatz LM, et at. Neurologic dysfunction in patients treated for small cell carcinoma of the lung: a clinical and radiological study. Int J Radiat Oncol Biol Physs 12: 385-389, 1986.

\section{Lee MY, Nauert C, Glass JP. Treatment-related} white matter changes in cancer patients. Cancer 57 : 1473-1482, 1986.

44. Lee JS, Umsawasdi Th, et al. Neurotoxiciry in long-term survivors of small cell lung cancer. Ine J Radiat Oncol Biol Phys 12: 313 - 321, 1986

45. So Nk, O'Neill BP, Frytak S, Eagan RT, Earnest. IVF, Lec RE. Delayed leucoencephalopathy in survivors with small cell lung cancer. Neurol 37: 11981201, 1987.

46. Laukannen MD, Klonoff $\mathrm{H}$, er al. The role of prophylactic cranial irridiation in limited stage small cell lung cancer: Clinical, neuropsychologic and CT sequelac. Ine J Radiat Oncol Biol Phys 14: 1109 1117. 1988

47. Frytak S, Shaw JN, et al. Leucoencephalopachy in small cell lung cancer parients receiving prophylactic cranial irridiation. Am J Clinic Oncol 12: 27 . 33, 1989

48. Johnson BE, Patronas N, et al. Neurologic, computed cranial tomographic, and magnetic resonance imaging abnormalities in patients with small-cell lung cancer: further follow-up of 6- to 13-year survivors. J Clin Oncol 8: 48-56, 1990

49. Fleck JF, Einhom L.H, et al. Is Prophylactic
Craniall Irridiation Indicated in Small-Cell Lung Cancer? J Clin Oncol 8: 209 - 214, 1990

50. Lishner M, Feld R, et al. Late Neurologic Complications after Prophylactic Cranial Irridiation in Patients with Small-Cell Lung Cancer: The Toronto Experience. J Clin Onscol 8: 215 - 221, 1990 
Neurologic disorders in 203 consecutive patients with small cell lung cancer: results of a longitudinal study 


\section{Introduction}

Smali cell lung cancer (SCLC) comprises about $25 \%$ of all lung cancers $[1,2]$. In patients SCLC is very aggressive and nearly always metastatic at the time of presentation, precluding therapy with surgery or chest irradiation alone [3]. The median survival of untreated patients is about 3 months from diagnosis, whereas combination chemotherapy, with or without radiotherapy, has provided improvements in median survival to almost a year, and $10 \%$ long-term, potentially cured survivors [4].

Neurologic disorders are a frequent and for the neurologist a fascinating problem in parients with SCLC. Central nervous system (CNS) metastases are diagnosed more frequently in SCLC than in other types of lung cancer [5]. Brain merastases are the most frequent sort of CNS metastases, and are an important cause of morbidity and mortality in patients with SCLC [6,7]. The actuarial probability of developing brain metastases increases with lengthening of survival to $50-80 \%$ at two years from diagnosis [6-9]. Because of its neuroendocrine properties, SCLC is associated with a wide array of parancoplastic syndromes [10-14]. Trearment of SCLC, the combination of chemotherapy and cranial irradiation in particular, is potentially neurotoxic and can contribute to brain injury as well [14-21].

Neurologic disorders have been studied retrospecrively, and mainly by pulmonolo- gists and oncologists in previous reports [5-21]. In the present article, the results of a prospective neurologic follow-up study are presented. The present study was undertaken to investigate the clinical frequency and course of the neurologic complications of SCLC.

\section{Patients and methods}

\section{Patients}

From January 1983 ro January 1993, 203 consecutive patients with microscopically proven SCLC were included in this prospective study. Till January 1994 minimal follow up was 1 year or uncil deach. Initial staging of these patients by a pulmonologist, was based on physical examination, standard blood and chemistry profile, chest $\mathrm{X}$-ray, CT-scan of the chest, ultrasound of the abdomen, radionuclide bone scan, fibre optic bronchoscopy, and bone marrow aspirate and biopsy. Limited disease (LD) was defined as tumor confined to the ipsilateral hemithorax, the mediastinum, and the ipsilateral and/or contralateral scalene and supraclavicular lymph nodes. In extensive disease (ED) tumor was found beyond these site.

\section{Treatment}

All parients were initially treated with a combination chemorherapy regimen, consisting of cyclophosphamide $1000 \mathrm{mg} / \mathrm{m} 2$, doxorubricin 45 or $50 \mathrm{mg} / \mathrm{mi} 2$, and etoposide $100 \mathrm{mg} / \mathrm{m} 2$ on day 1,3 , and 5 for at least five cycles. Chemotherapy was sometimes followed by radiotherapy to 
Patients

Disease stage

limited

extensive

Toral 79129

Men / Women

$59 / 15$

$111 / 18$

Median age at diagnosis (range)

$64(39-84) 65$

Complete remission

37

Prophylactic cranial irradiation

17
30

5

Table 1. Pariene characteristics.

the primary tumor site. Restaging was performed after five courses of chemotherapy and consisted of physical examination, and repericion of those examinarions which were abnormal at the initial staging procedure; complete remission (CR) was defined as a total resolution of all detectable lesions.

Only patients who obtained CR were candidates for trearment with PCI. Till 1986 LD and ED patients could opt for PCI, after 1986 LD patients only, and in 1990 PCI was excluded from the treacment protocol. Berween 1983 and 1988, two eligible LD patients refused PCI. Patien characteristics and treatment specifications are listed in fable 1. PCI was administered to the entire cranial content following completion of chemorherapy. Patients were truated with a linear accellerator, usually $6 \mathrm{MV}$ photons, using two lateral opposed ficlds. The dose was calculared in the mid plane, and delivered in d:ily fractions of 3 (jy. 7 times a weck. up to a cotal dose of 30 ( 5 . During 1988 and 1490 the radiation technique was changed, the fraction dose heing lowered to $2 G y, 5$ fracrions per weck up to a total dose of $30 \mathrm{G}$.

Palliative treatment of manifest brain metastases consisted of daily treatment with fractions of 3 Gy, 4 times a week, up to a total dose of $30 \mathrm{~Gy}$. Treatment of leptomeningeal metastases consisted of intrathecal methotrexate and systemic corticosteroid medication, which was sometimes combined with local radiotherapy at symptomatic sites. Therapy for spinal metastases comprised radiotherapy concurrent with corticosteroid medication. Radiotherapy was initiated a few hours after diagnosis was made if signs of spinal cord compression were present, otherwise within 48 hours. Dose and schedule were tailored to site and extent of metastasis. 
- chemotherapy

- unknown cause

- diabetes mellitus

- alcohol

paraneoplastic syndromes

- SIADH

- Lambert-Eaton myasthenic syndrome

- subacute cerebellar degeneration

- limbic encephalicis

orher

encephaloparhy

- possible treatment-related

- merabolic

- steroid mỵoparhy

- radiation plexopathy

- cerebrovascular accident
16

9.2

11

6.3

3

1.7

1

0.6

16

9,2

12

6.9

8

4.6

4

2.3

2

1.1

1

0.6

1

0.6

Table 2. Neurologic disorders in 203 consecutive patients with small cell lung cancer. $\mathrm{SIADH}=$ syndrome of inappropriate secretion of antidiuretic hormone. 


\section{Neurologic follow-up}

Patients were seen by a neurologist at diagnosis and at quarterly intervals (biannually after a year). Pretreatment a CTscan of the brain was performed until 1989, thereafter a MRI. More frequent neurologic consultations and other auxiliary diagnostic tests took place if required. In patients wirh a long-term survival (defined as 2 years or longer from diagnosis) an additional CT-scan of the brain or MIRI was performed. Abnormal brain functioning found in long-term survivors, was designated as possible treatment related encephalopathy unless otherwise clearly explainable.

\section{Statistics}

Overall survival was calculated from SCLC diagnosis to death or end of observation period, brain metastatic free survival from SCI.C. diagnosis to the diagnosis of brain metastilses or end of observation period. Survival curies were estimated by the Kaplan-Mcier method, differences tested by the Log-rank test. A p-value of less than 0.05 was considered to be statistically significant.

\section{Results}

A total number of 174 neurologic disorders were diagnosed in 134 patients (66\%); 23 patients had 2 neurologic disorders, and 9 patients had more than 2 differene neurologic disorders. The diverse disorders are listed in rable 2 . The majority of the complications, 161 (9.3\%), were directly related to SCLC or its treatment.
Metastatic complications predominated.

Brain metastases were found at initial diagnosis of SCLC in 27 patients, and during the course of disease in 52 patients. Histopathologic examination of the brain metastases after autopsy $(\mathrm{n}=$ 12) or neurosurgical intervention $(n=3)$ revealed a different diagnosis in 2 patients (another primary tumor $n=1$, non-SCLC relapse after CR of SCLC $n=$ 1). In the remaining parients the diagnosis SCLC was confirmed.

Brain metastatic free survival of LD and ED patients was significantly different ( $p$ $<.01$, Log-rank test). Two years from diagnosis, the cumulative risk of brain metastases reached $47 \%$ for LD and $69 \%$ for ED patients, see figurr 1 . The overall survival of patients with initial brain metastases did not differ significantly from the survival of ED parients without initial brain metastases $(p=.12, \mathrm{Log}$ rank resc). Survival following diagnosis of brain metastasis was significantly longer for patients with initial brain metastases than for L.D and ED patients with delayed brain metastases $(p<.01, \log -\mathrm{rank}$ test), see figure 2. The median survival of 12 patients with initial CNS-limited disease was not better than the median survival of other parients with inirial brain metastases, 2.1 months (range, 0.6 to 15.8 ) versus 5.1 months (range, 0.2 to 25.2). Eight out of 12 parients with inirial CNS-limited disease died early due to various complications (sepsis $n=5$, and haemorrhage in cerebral metastasis $n=1$ ) or progressive disease (no response $n=1$, and therapy refused $n=1$ ). 


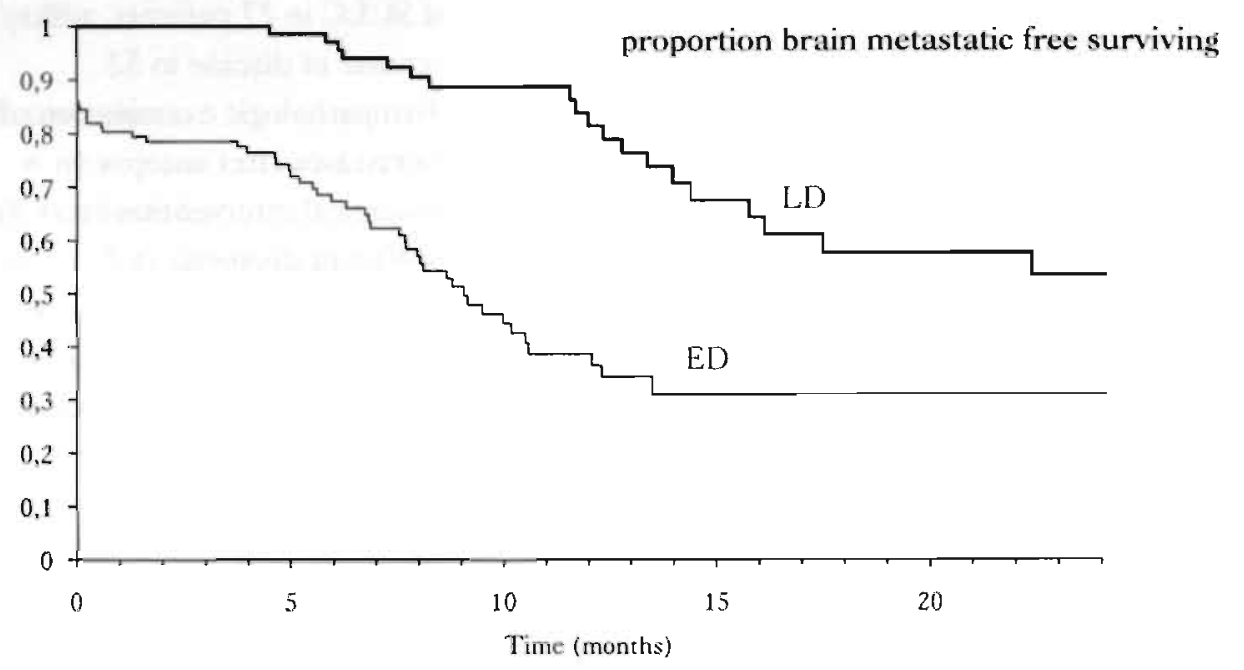

Figure 1. Cumulative risk of brain metastases in limited (LD) and exrensive disease (ED) patients.

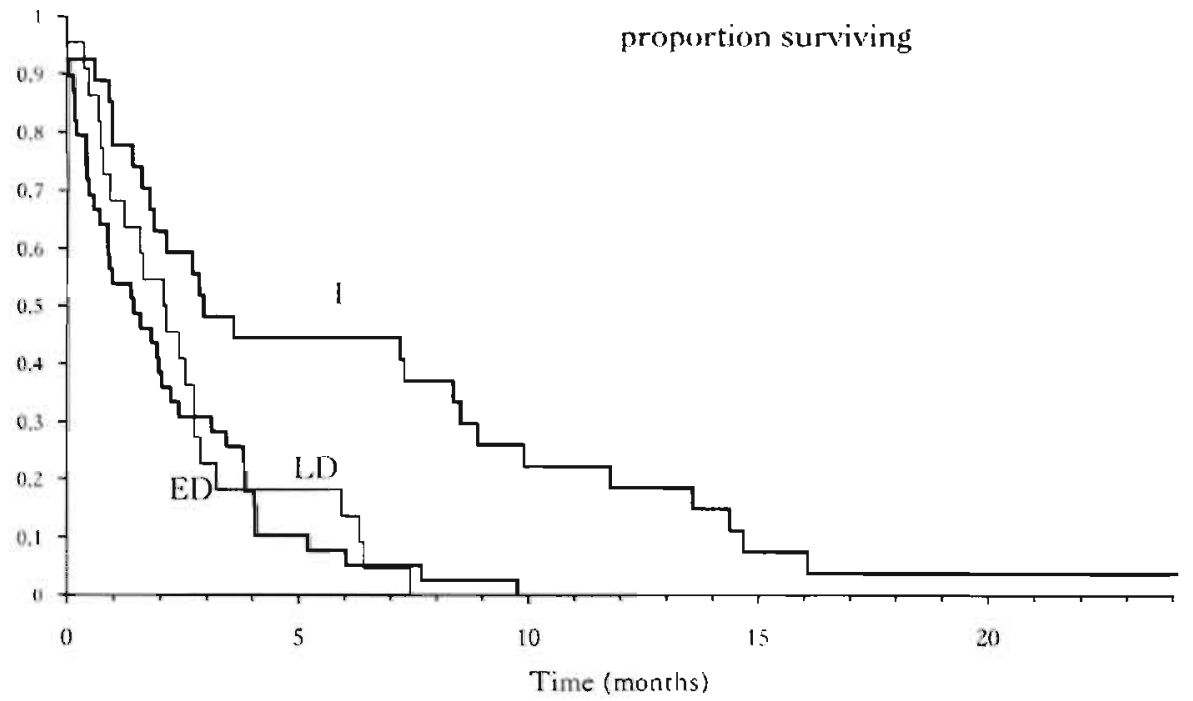

Figure 2. Survival following diagnosis of brain metastases for parients with initial brain merastases diagnosed prior to therapy (I), and limited (LD) and extensive disease (ED) patients with delayed brain metastases diagnosed during or after therapy. 

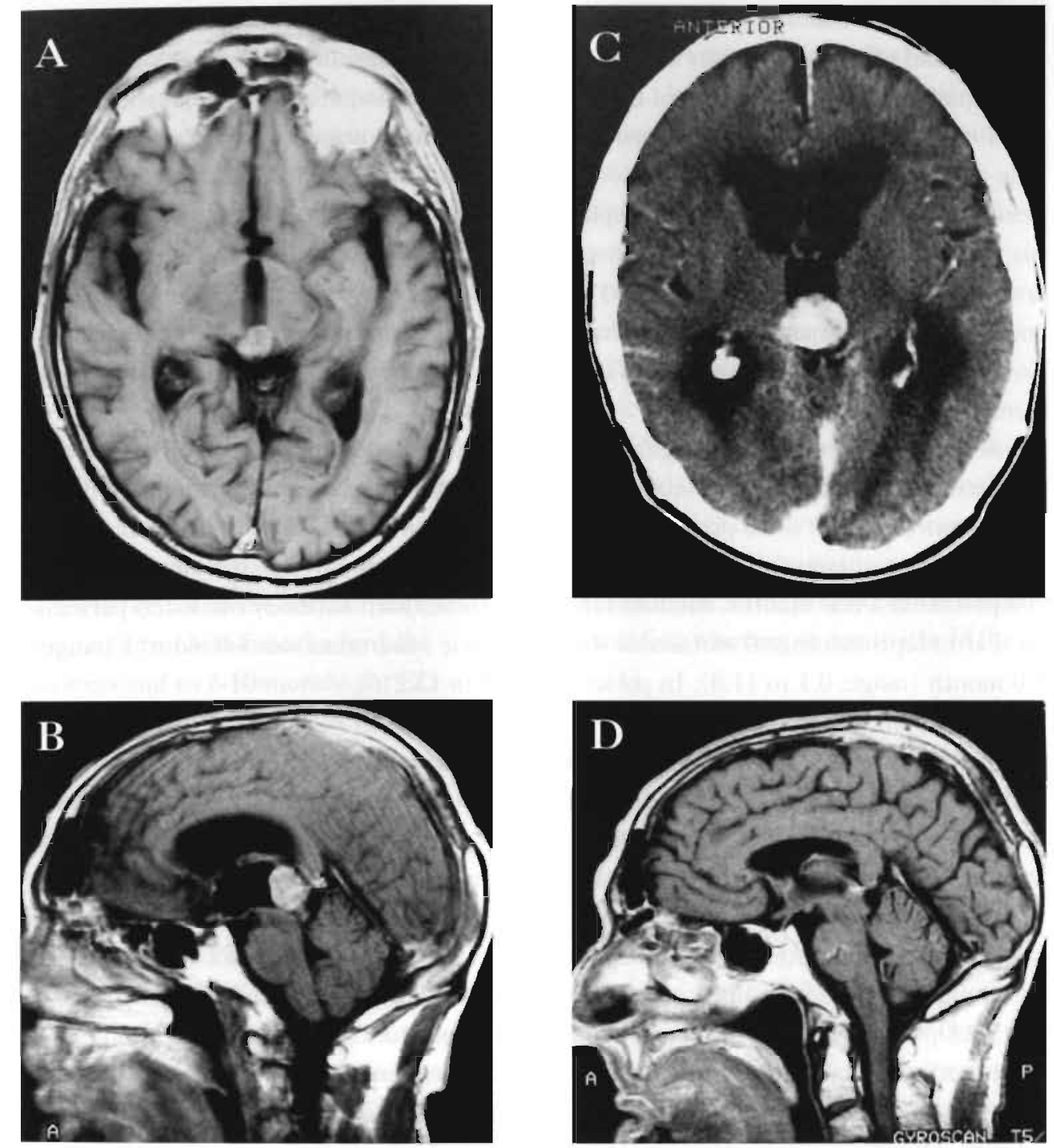

Figure 3. Staging MR scan with solitary mecastasis in pineal gland (A). The volume of the metastasis remained unchanged for 13 monchs with chemotherapy alone (B). Secondary tumor grow th and the hydrocephalus (C) were treared with vertriculair drainage and cranial irridation, which yiclded complete radiologic and neurologic remission (D) for the remaining 6 months of the parient's life. 
The volume of a solitary metastasis in the pineal gland of a neurologically asymptomatic patient with a CNS-limited disease remained the same for 13 months using only chemotherapy, see figure 3 .

Secondary tumor growth and hydrocephalus were treated with ventricular drainage and cranial irradiation, which obtained complete radiologic and neurologic remission till dearh, 6 months later due to systemic relapse.

Clinical diagnosis of leptomeningeal metastases was confirmed by liquor cytology or autopsy in 13 of 22 patients. In most patients, therapy provided relief of symptoms for a few months. Median survival after leptomeningeal metastasis was 1.0 month (range, 0.1 to 11.8 ). In patients with back pain or signs of a spinal cord lesion, ancillary diagnostic tests for spinal metastases were carried out. The 14 parients with epidural metastases lived a median of 1.6 months (range, 0.2 to 14.7). Two patients with back pain only, lived 0.4 and 2.3 monchs afrerwards. Spinal cord metastasis was found in 3 parienes by MRI. All parients with spinal cord metastases suffered from back pain at diagnosis.

The mose frequene paraneoplastic syndromes was SI. ID)H (rikdrome of mappropriate secretion of ancidiuretic hormone). diagnosed in 11 paticnes $\left(6.3^{m}\right.$. who presented with a hyponatremia inducied crlecphaloparhy, ar the rime of diannosis of Sc itc: or early during the course of the disciase. In most parients SI.MI)l I subsided with chemotherilp! of SCLLC: Median survival of patients with SIADH was 6.8 months (range 0.1 to 13.6).

Antibody mediated paraneoplastic neurologic syndromes, were diagnosed in 5 parients (1.7\%) only. Lambert-Eaton myasthenic syndrome was diagnosed in one patient 6.7 months before diagnosis of SCLC was made. The clinical manifestations of limbic encephalitis existed in one patient 3.5 months prior to diagnosis of SCLC. The course of the ancibody mediated paraneoplastic syndromes was not influenced by the treatment of SCLC, and either remained stable or progressed slowly. Median survival of patients with antibody mediated paraneoplastic syndromes was 4.0 months (range 0.7 to 13.2 ).

Adverse effects of treatment were noticed in 23 parients (13\%); peripheral neuropathy due to chemotherapy was reversible, whereas the other treatment-related complications were not. The number of sensory neuropathies was probably underestimated in the total number of polyneuroparhies; during chemotherapy many patients complained of temporary numbness or tingling sensations over the distal parts of their extremities, mostly without further clinical evidence of a polyneuropathy or clectromyographic abnormaliries. Possible treitment-related encephalopathies were diagnosed in 8 of the 18 longrerm survivors (7 wich and 1 without P(I). Simproms and signs had an insidious onset within 6 months following the termination of PCI, and comprised memory disturbances in 4 patients, 
memory disturbances with temporary lethargy in 2 patients, and progressive memory disturbances with apathy in 2 patients. Except for the latter 2 patients, symptoms remained stable. Steroid myopathy was diagnosed in two patients with brain metastases and a protracted course of disease.

\section{Discussion}

The natural course of SCLC, known of as rapidly progressive and almost always facal, has been protracted by the use of chemotherapy with or without the use of radiocherapy. The median survival has improved to 13-16 months for LD parients and to 7-10 months for ED patients [22,23]. A minority of patients with SCLC is cured, $10 \%$ of all patients, and $20 \%$ of parients with favourable prognostic factors [24]. With lengthened survival some clinical manifestations of SCLC have become more apparent and so has the risk of CNS spread.

Approximarely $10 \%$ (had brain metastases at diagnosis of SCLC [6.25], a further $20 \%$ developed brain merastases during therapy [6.25], and about $50 \%$ had brain metastases at autopsy $[6,8,25]$. At 2 years from diagnosis, the cumulative risk at brain metastases reached $50-80 \%$ for patients not treated with PCI and in CR [6-8], and nearly $100 \%$ for patients who did not achieve CR regardless of treatment with PCI [26].

In the present study, frequencies of brain metastases at diagnosis, during treatment, and at 2 years from diagnosis were in accordance with the data of other studes $[6,8,25]$. Autopsy rate was relatively low, revealing a different histology of brain metastases in $13 \%$ of patients.

Explanations for the differences in histology may be found in alterations of cell morphology with therapy or time, and development of a second primary tumor. [27-29]. Studies investigating the prognostic implicarions of histologic subryping of SCLC were inconclusive as yer [30]. A relationship between histologic subryping of SCLC and brain metastases Was nor found either, but hope existed that histologic subtyping could be useful in deciding wherher or not to use PCI [30..31].

The prognosis of pacients with initial presentation of brain metastases is not necessarily worse. If ereated with cranial irradiation when brain metastases appeared, Hazel et al [32] found no differences in survival between LD patients and parienrs with the CNS as sole metastatic site. Because of the high frequency of intracranial metastases wirh the use of chemotherapy, it was assumed that the C.NS was a relative chemotherapy sanctuary enclosed by the blood brain barrier.

Reports of radiologically proven responses of cerebral metastases to systemic chemotherapy [33] encouraged several investigators to underrake trials with systemic chemorherapy for brain metastases [34].

Kristensen et al [35] compiled from data in the literature a cumulative response 
rate of $75 \%$ and complete response rate of $44 \%$ for therapeutic cranial irradiation, and a cumulative cumulative response rate of $43 \%$ and complete response rate of $13 \%$ for delayed brain metastases. As the response of initial brain metastases to chemotherapy was almost as good as to cranial irradiation, it seems logical to wait for the effect of first line chemotherapy. In patients with delayed brain metastases who probably developed resistance to cytotoxic drugs and therefor have a shortened life expectancy, brain metastases should be treared with irradiation.

Irradiation attains a slightly better response rate and is less toxic than chemotherapy [35].

In the present study, survival of parients with CNS-limited disease was poor because 8 of 12 patients (66\%) died early from complications. Treatment of initial brain metastases generated a significancly better response than treatment of delayed brain metastases, in terms of survival. The better response could be caused by a greater sensitivity of the tumor or the more intense treatment given, during the initial stage of the disease. Only one patient was treated for brain metastases with chemotherapy alone; in this case, a solitary brain metastasis in the pineal gland remained clinically silent for a considerable time. When the pineal gland metastasis finally became symptomatic, radiotherapy yielded CR till death, neurologically and radiologically. Though the pineal gland is not a good example with irs strong vascularisation and its relatively untight blood brain barrier, this case raises the question whether initial treatment of brain metastases with chemotherapy should be followed by consolidation radiotherapy.

Whether or not chemotherapy treated patients with initial brain metastases should receive consolidation cranial irradiation remains to be seen [35].

In contrast to symptomatic treatment of brain metastases, $\mathrm{PCI}$ may contribute in curing parients. Rosenstein et al [36] found PCI effective in increasing survival "LD patients with durable thoracic control. The use of PCI is still under discussion: in randomised srudies it reduced the frequency of brain metascases from 25 to $5 \%$, but did not benefir survival and wits assuciared with an increased risk of CNS roxicity [37]. In the present study, we found possible trcatment-related impairmene in $61.33 \%$ ) and disibility in $2(11 \%)$ of the 18 long-term survivors. Of the 8 parients wirh pussibl: trearment-relared brain injury 7 had received PCl. However, in individual patients it remains very difficult to identify retrospectively causal factors for the racher aspecific features of possible treatment-related brain injury. The most common anatomic abnormalities shown by CT scan or MRI following PCI treatment are white matter lesions and general brain atrophy. These abnormalities are linked to a wide range of clinical manifestations, and are indistinguishable from normal ageing processes as leucoaraiosis, by imaging techniques [38] 
Paraneoplastic syndromes can be divided in hormone mediated and antibody mediated. Up to $54 \%$ of patients may have elevated hormone levels [39]. However, in the literarure, the clinical frequency of a hormone mediated paraneoplastic syndromes as SIADH, varies from $9.5 \%$ to $12 \%$ [10]. In the present study, the frequency was lower as we were focused on neurologic abnormalities and not all patients with SIADH have a neurologic presentation. Antibody mediated neurologic paraneoplastic syndromes have a frequency of approximately $3 \%$ [40], coinciding with our results percentage wise. Therapy of SCLC was effective for the hormone mediated, but not for the antibody mediated paraneoplastic syndromes.

The longitudinal nature of the present study yielded a high frequency of neurologic disorders in SCLC parients, more so than in previous recrospective reports [521]. Brain metastases were the most common complication. The different concepts regarding the treatment of brain metastases need further invesrigarion.

\section{References}

1. Chute CG, Greenberg ER, Baron J, Korson R, Baker J, Yates J. Presenting conditions of 1539 population-based lung cancer patients by cell type and stage in New Hampshire and Vermont. Cancer 56: 2107-2111, 1985.

\section{Silverberg E, Boring CC, Squires TS. Cancer sta-} tistics, 1990. CA Cancer J Clin 40: 9-26, 1990.

\section{Osterlind $\mathbf{K}$, Ihde DC, Ettinger DS, Gralla RJ,}

Karrer K, Krauss S Staging and prognostic factors in small cell carcinoma of the lung. Cancer Trear Rep 67: 3-9, 1983.

4. Hansen HH, Selawry OS, Simon R, Carr DT, van Wijk CE, Tucker RD. Combination chemotherapy of advanced lung cancer: a randomized trial. Cancer 38 : 2201-2207, 1976.

5. Newman SJ, Hansen HH. Proceedings: Frequency, diagnosis, and treatment of brain metastases in 247 consecutive patients with bronchogenic carcinoma. Cancer 33: 492-496, 1974.

6. Pedersen AG. Diagnosis of CNS metastases from SCLC. In: Lung cancer: Basic and clinical aspects. Boston. (MA): Martinus Nijhoff, 1986, 153-182.

7. Sculier IP, Feld R, Evans WK, DeBoer G, Shepherd FA, Payne DG, et al. Neurologic disorders in parients with small cell lung cancer. Cancer 60 : 2275-2283, 1987.

8. Komaki R, Cox JD, Whitson W. Risk of brain nectastasis from small cefl carcinoma of the lung related to length of survival and prophylactic irradiation. Cancer Trear Rep 65: 811-814, 1981.

9. Nugent JL, Bunn PA Jr, Matthews MJ, Ihde DC, Cohen MH, Gazdar A. CNS metastases in small cell bronchogenic carcinoma: increasing frequency and changing pattern with lengthening survival. Cancer 44: $1885-1893,1979$.

10. Abeloff MD, Trump DL, Baylin SB. Ectopic 
adrenocorticotrophic (ACTH) syndrome and small cell carcinoma of the lung - assessment of clinical implications in patients on combination chemotherapy. Cancer 48: 1082-1087, 1981.

11. Lokich JJ. The frequency and clinical biology of the ectopic hormone syndromes of small cell carcinoma. Cancer 50: 2111-2114, 1982.

12. List AF, Hainsworth JD. Davis BW, Hande KR, Greco FA, Johnson DH. The syndrome of inappropriate secretion of antidiuretic hormone (SIADH) in small-cell lung cancer. J Clin Oncol 4: 1191-1198, 1986.

13. Anderson NE, Cunningham JM, Posner JB. Autoimmune pathogenesis of paraneoplastic neurological syndromes. Crit Rev Neurobiol 3: 245-299, 1987.

14. Newsom-Davis J. Lambert-Eaton myasthenic syndrome. Springer Semin Immunopathol 8: 129. 140, 1985 .

\section{Catane R. Schwade JG, Yarr I. Lichter AS.} Tepper JE. Dunnick NR. Follow-up neurological evaluation in patients with small lung carcinoma treated with prophylacric cranial irradiation and chemotherapy. Int J Radiat Oncol Biol Phys 7: 105-109, 1981.

16. Craig JB, Jackson DV, Moody D, cruz JM, pope EK. Powell BL. Prospective evaluation of changes in compured cranial tomography in patients with small cell lung carcinoma treated with chemotherapy and prophỵlactic cranial irradiation. J Clin Oncol 2: 1151 $1156,1984$.

17. Frytak S. Eamest F 4th, O'Neill BP. Lec RE. Creagan ET, Tratumann JC. Magnetic resonance imaging for neurotoxicity in long-term survivors of carcinoma. Mayo Clin Proc 60: 803-812, 1985.

18. Johnson BE, Becker B, Goff WB 2d, Petronas N. Krehbiel MA, Makuch RW. Neurologic, neuropsychologic, and compured cranial tomography scan abnormalities in 2- to 10-year survivors of small-cell lung cancer. J Clin Oncol 3: 1659-1667. 1985.
19. Laukkannen E, Klonoff H, Allan B, Grade D, Murray $N$. The role of prophylactic brain irradiation in limited stage small cell lung cancer: clinical, neuropsychologic, and CT sequelae. In $\mathrm{j}$ Radiat Oncol Biol Phys 14: 1109-1117, 1988.

20. Frytak S, Shaw JN, O Neill BP, Lee RE, Eagan RT, Shaw EG. Leucoencephaloparhy in small cel! lung cancer patients receiving prophylactic cranial irridiation. Am J Clin Oncol 12: 27-33, 1989.

\section{Johnson BE, Patronas N, Hayes W, Grayson J,} Becker B. Gnepp D. Neurologic, computed cranial tomographic, and magnetic resonance imaging abnormalities in parienrs with small-cell lung cancer: further follow-up of 6- to 13-year survivors. J Clin Oncol 8: 48-56, 1990.

\section{Livingston RB, Moore TN, Heilbrun L,}

Bottomley R, Lehane D, Rivkin SE. Small-cell carcinoma of the lung: combined chemotherapy and radiation: a southwest Oncology group study. Ann Intern Med 88: 194-199, 1978.

23. Havemann K. Wolf M. Holle R. Gropp C. Drings $P$. Manke HG. Alternaring versus sequential chemotherapy in small cell lung cancer. a randomised german multicenter trial. Cancer 59: 1072-1082, 1987.

24. Hansen M, Hansen HH, Dombernowsky P. Long-term suvival in small cell carcinoma of the lung. JAMA 244: 247-250, 1980.

\section{Hirseh FR. Hansen HH. Paulson OB. Central} nervous system metastases in small cell lung cancer. In: Ongerboer de Visset BW, Bosch DA, WoerkomEykenboom WMH, editors. Neuro-Oncology clinical and experimental aspects: Developments in oncology, 3. The Hague: Marrinus Nijhoft, 1980: 140-166.

26. Rosen ST, Makuch RW, Lichter AS, Ihde DC, Marthews MJ. Minna JD. er al. Role of prophylactic cranial imadiation in presention of central nervous system metastases small eell lung cancer. Potential benefit restricted to patients with complete response. Am I Med 74:615-624, 1983.

27. Sehested M, Hirsch FR, Osterlind K, Olsen JE. 
Morphologic variations of small cell lung cance. A histopathologic study of pretreatment and posttrearment specimens in 104 patients. Cancer 57: 804 807, 1986.

28. Matthews MJ. Effects of therapy on the morphology and behavior of small cell carcinoma of the lung: A clinicoparhologic study. In: Muggia F, Rozenzweig M, editors. Lung cancer: Progress in therapeutic research. New York: Raven Press, 1977: 15-165.

\section{Abeloff MD, Eggleston JC, Mendelsohn G,} Etringer DS, Baylin SB. Changes in morphologic and biochemical characteristics of small cell carcinoma of the lung. A clinicoparhologic study. Am J Med 66: $757-764,1979$.

30. Osterlind K, Ihde DC, Ettinger DS, Gralla RJ, karrer $K$, krauss S. Staging and prognostic factors in small cell cancer of the lung. Cancer Treat Rep 67: 3-9, 1983.

\section{Oosterhour van AG, Thunnissen FB, Volovics A,} van de Pol M, tenVelde GP, Twijnstra A. The role of histopathologic subtyping in predicting neurologic complications in small cell lung cancer. Int J Oncol 4: 201-205, 1994.

32. Hazel van GA, Scotr M, Eagan RT. The effect of CNS metastases on the survival of patients with small cell cancer of the lung. Cancer 51: 933-937. 198.3.

33. Kantarjian H, Farhạ PA, Spizzer G, Murphy WK. Valdivieso M. Systemic combination chemotherapy as primary treatment of brain metastasis from lung cancer. Sourh Med J 77: 426-430, 1984.

34. Postmus PE. Haasma-Reiche H, Sleijfer DT, Kleisbauer JP, ten Velde G. Kirkpatrick A. Highdose etoposide for central nervous system metastases of small cell lung cancer. Preliminary results. Eur J Respir Dis 70 Suppl 149: 65-71. 1987.

\section{Kristensen CA, Kristjansen PE, Hansen HH:} Systemic chemotherapy of brain metastases from small-cell lung cancer: a review. J Clin Oncol 10: 1498-1502. 1992.
36. Rosenstein M, Armstrong J, Kris M, et al. A reappraisel of the role of prophylactic cranial irradiation in limited small cell lung cancer. Int J Radiat Oncol Biol Phys 24: 43-48, 1992.

37. Pedersen AG, Kristjansen PE, Hansen HH. Prophylactic cranial irradiation and small cell lung cancer. Cancer Treat Rev 15: 85-103. 1988.

38. Constine LS, Konski A, Ekholm S, McDonald S, Rubin P. Adverse effects of brain irradiation correlated with MR and CT imaging. Int J Radiat Oncol Biol Phys 15: 319-330, 1988.

39. Hansen M, Hansen H. Hirsch F, et al. Hormonal polypepridesand amine metabolitesin small cell carcinoma of the lung, with special reference to stage and subrype. Cancer 45: 1432-1437, 1980.

\section{Elringtom GM, Murray NMF, Spiro SG,} Newsom-Davis J: Neurological paraneoplastic syndromes in patients with small cell lung cancer. A Prospective survey of 150 patients. J. Neurol Neurosurg Psychiatry 54; 764-767,1991. 
The role of histopathologic subtyping in predicting neurologic complications in small cell lung cancer 


\section{Many early studies have focused on the} clinical implications of histologic subryping of small cell lung cancer (SCLC) [111]. A few studies reported differences in metastatic CNS patterns for particular SCLC subtypes [1-3] and one of the authors [1] suggested that histologic subtyping could be useful in deciding whether or not to use prophylactic cranial irradiation (PCI). In SCLC cell lines, the classic small and variant subrypes show obvious differences in morphology, expression of neuroendocrine markers and oncogenes, and resistance to chemotherapy and radiotherapy [12-14]. However, initial studies investigating histologic subtyping of SCLC revealed conflicting data with respect to prognosis [1-8]. This was attributed to a lack of reproducible criteria, which is why the pathology panel of the International Association for the Study of Lung Cancer (IASLC) developed a new subclassification $[15,16]$. This classification system was correlated to cell culture work and recognizes three subtypes: small, mixed, and combined $[15,16]$ and offers the best inrerobserver reproducibility thus far $[9,10,16]$.

Relationships between this classification system and neurologic complications have hardly been investigated [11]. In an earlier analysis [11] our patient population was divided a priori into subgroups and half as large. The purpose of the present study was to reevaluate the prognostic relevance of the IASLC classification sys- tem with regard to propensity for neurologic complications, including CNS metastases. Therefore, the present retrospective study histologic subtyping of SCLC was related to the findings of prospective neurologic follow up.

Patients and methods

This study comprised 239 consecutive patients with a tissue diagnosis of SCLC, registered at the Department of Pulmonary Diseases of the University Hospital Maastricht from October 1980 to January 1992. Initial craluation by the pulmonologist included physical "s:imination, standard blood and chemistry profile, chest $x$-ray, bone scan, bone marrow aspirate and biopsy, ultrasound of the upper abdomen, and a CT -scan of the chest and brain. MRI (Magnetic Resonance Imaging) of the pelvis, spine, and brain was performed after 1990. Limited disease (LD) was defined as tumor confined to the ipsilateral hemithorax, the mediastinum, and the ipsilateral or contralateral scalene and supraclavicular lymph nodes. In extensive disease (ED) the tumor was found beyond these sites. Patients were initially treated with chemotherapy, consisting of cyclophosphamide $1000 \mathrm{mg} / \mathrm{m} 2$. doxorubicin 45 or 50 $\mathrm{mg} / \mathrm{m} 2$, and ecoposide $100 \mathrm{mg} / \mathrm{m} 2$ on days 1,2 , and 3 for at least five cycles. Radiotherapy to the primary tumor was applied to all patients until 1982, thereafter only if local tumor response was partial. Standard criteria of the World Health Organization were used in the definition 
of responses. Patients who went into CR were non-randomly treated with PCI, at a total dose of 30 Gray for the entire cranial content in 10 fractions of 3 Gray over 2 to 3 weeks. PCI was not used after 1990 . All patients were seen by a neurologist when diagnosed with SCLC and at quarterly intervals during the first year, biannually thereafter. Neurologic complications were documented using appropriate tests.

\section{Pathology}

One of the aurhors, unaware of the clinical outcome, reexamined the pretreatment histologic or cytologic specimens on which the original diagnosis was based. All cytologic specimens were Giesma stained. The SCLC subtyping of the histologic as well as the cytologic specimens was done according to the morphologic criteria proposed by the pathology panel of the IASLC [16]. In brief, "small cell carcinoma" is characterized by oval, round, or fusiform nuclei with diffusely distributed chromatin and small nucleoli, nuclear molding, and indistinct cell borders. The "mixed small cell carcinoma" is a small cell carcinoma that contains cells resembling those of large cell lung carcinomas with a prominent eosinophilic nucleolus with a paranucleolar halo. The "combined small cell carcinoma" is SCLC combined with a more or less prominent component of squamous or adenocarcinoma.

\section{Statistical analysis}

The following statistical procedures were used to analyze the data: chi-square tests for comparison of patient subgroups; logistic regression to investigate the prognostic significance of age, sex, histologic subtypes and disease stage with respect to developing brain metastases. The Cox proportional hazards model was used to investigate the prognostic value of the same factors with respect to brain metastatic free survival. Survival curves were estimated by the Kaplan-Meier method, differences tested by the log-rank test.

\section{Results}

Slides from 7 of the 239 parients slides were not retrievable, while only autopsy material was available for another 14 patients. In 8 cases the initial diagnosis of SCLC was changed to atypical carcinoid $(n=2)$, Merckel cell tumor $(n=1)$, squamous cell carcinoma $(n=2)$, adenocarcinoma $(n=2)$ or undifferentiated large cell carcinoma $(n=1)$. These patients were not evaluated in the statistical analysis. Thus, 210 parients remained for morphologic subtyping. 187 parients $(85 \%)$ were classified as having "small cell carcinoma" and 31 parients (15\%) as having "mixed cell carcinoma". For the small cell type the diagnosis was based on 139 histologic slides and 39 cytologic slides. For the mixed cell type the basis was 26 histologic and 5 cytologic slides. Only one patient was classified as having "combined small cell carcinoma". In the further statistical analysis mixed and combined subrypes were grouped. 


$\begin{array}{lllll}\text { Age } & \text { median (range) } & 64(41-83) & 67(48-83) & 69(49-81) \\ \text { Gender } & n \text { (\% subtype) } & & \\ & \text { male } & 149(84) & 29(91) & 21(100) \\ & \text { female } & 29(16) & 3(9) & 0(0)\end{array}$

Disease stage n (\% subrype)

$\mathrm{I}, \mathrm{D}$

ED
$69(39)$

109 (61)
$12(38)$

Table 1. Clinical data of 231 SCLC patients classifed by a histologic subtype; small $(n=178)$, mixed (mixed small cell/large cell $n=31$ and combined $n=1$ ), and no subtype (no slides available $n=7$ and only autopsy material $n=14$ ); $E D=$ extensive disease.

The elinical characteristics of the 231 parients with SCLC are shown in table 1. The frequencies of some of these characteristics fluctuated during the 11 years of follow up. Age, divided into subgroups (younger than $58,58-65,65-73$, older than 73), changed with time; until 1982 there was a relatively high proportion of patients younger than 58; afterwards the number of parients younger than 58 and older than 73 decreased and the number of parients aged 58-73 increased. The percentage of female patients increased over these 11 years, from 0 to 15 . The proportion of small versus mixed subtype (85/15), and LD versus ED (40/60) remained the same over the years. The response to therapy did not van over these 11 years; abour $20-30 \%$ of the patients went into CR. In time, PCI was increasingly reduced; it was used in $60 \%$ of the parients until 1982, in $15 \%$ between 1983 and 1990, and in none rhereafter.

The neurologic complications evaluated at the time of diagnosis and during further follow up are listed in table 2.

Metastatic complications predominated. Paraneoplastic complications with a neurologic presentation included pure neurologic paraneoplastic syndromes and neurologic syndromes caused by ectopic hormone production. In fact the number of paraneoplastic syndromes in the whole population was larger, but these patients had no neurologic symptoms and were therefore outside the scope of this study. The number of sensory neuropathies was probably underestimated in the total number of polyneuropathies: during chemotherapy many patients complained of temporary numbness or tingling sensations over the distal parts of their extremities, 
Neulogic complications:

- toral n (\%total)

$144(100)$

$91(64)$

$61(42)$

$18(13)$

$12(8)$

\section{Paraneoplastic complications:}

- total

-SIADH

- Lambert eaton

- cerebellar degeneration

- myelicis transversa

- limbic encephalitis

\section{Other complications:}

- total

- polyneuropachy

- encephalopathy

- cerebrovascular disease

- myopathy

Table 2. Number $(n)$ and percentage of total (\% cotal) of neurologic complications diagnosed in 210 small cell lung cancer patents; CNS=central nervous system; SIADH=syndrome of inappropiace ADH secretion.

mostly withour further clinical evidence of a polyneuropathy or electromyographical abnormalities. Apart from 2 metabolic encephalopathies in relatively old and severely ill patients, 11 possibly PCI induced encephaloparhies were diagnosed. The possibly PCI induced encephalopathies had an insidious onser within 6 months after termination of PCI. These involved memory disturbances $(n=9)$, visual symptoms $(n=1)$, ataxia $(n=2)$, and dementia syndromes $(n=2)$ and were irreversible, though not progressive for most of the patients. Myopathy, diagnosed in one pacient, was induced by corticosteroid medication. 
Histologic subtype

Complications:

- total CNS metastases

- brain metastases

- leptomeningeal metastases

- epidural metastases

- paraneoplastic syndromes
Time periods

(range)

- brain merastatic-free survival

- overall survival

- overall survival for patients with paraneoplastic syndrome
Small cell Mixed cell p value

$\mathrm{n}(\%$ subtype)

$78(44)$

$52(29)$

$17(10)$

$9(5)$

$11(6)$

$\mathrm{n}(\%$ subrype $)$

$\mathrm{n}(\%$ subrype)

$13(41)$

0.96

$9(28)$

0.90

$1(3)$

0.19

$3(9)$

0.33

$0(0)$

0.15

median (range) median

$532(0-3748)$

$670(0-891)$

0.75
$208(6-891)$

Table 3. Occurence of merascatic and parneoplastic complicarions, and survival data according to histologic subrype.

Clinical outcome according to histologic subrype is presented in table 3 , brain metastatic free survival curves in figure 1 . Statistical analysis yielded no significant differences in metastatic CNS patterns (chi-square tests). The percentage of brain metastases was similar for boch histologic subtypes (about $30 \%$ ). Brain metascases were diagnosed in $13(26 \%)$ patients with LD and $49(38 \%)$ with ED. Upon diagnosis of lung cancer, brain metastases were present in 9 patients with small cell type (5\%) and 3 patients with mixed cell rype (9\%).

Prognostic relevance for developing brain metastases was investigated with regard to age, gender, histologic subtype, and disease stage (logistic regression). Brain metastases (upon diagnosis of lung cancer or developed during further follow up) were less common in older patients $(p=0.05)$ and those with LD $(p=0.03)$. The occurrence of brain metastases was nor associated with histologic subtype $(p=0.68)$ or gender $(p=0.25)$.

The brain metastatic free survival was calculated from the moment of diagnosis of lung cancer. Histologic subtype, age, and gender were not significantly associated with the brain metistatic free survival; only discase stage was (Cox proportional hazards model). As cxpected, LD had a better prognosis than ED ( $p=0.0001)$. Analysis of the Kaplan-Meier curves with the log-rank test yielded no differences for histologic subrype $(p=0.75)$ or brain metastatic free survival. Paraneoplastic syndromes with a neurologic presentation 


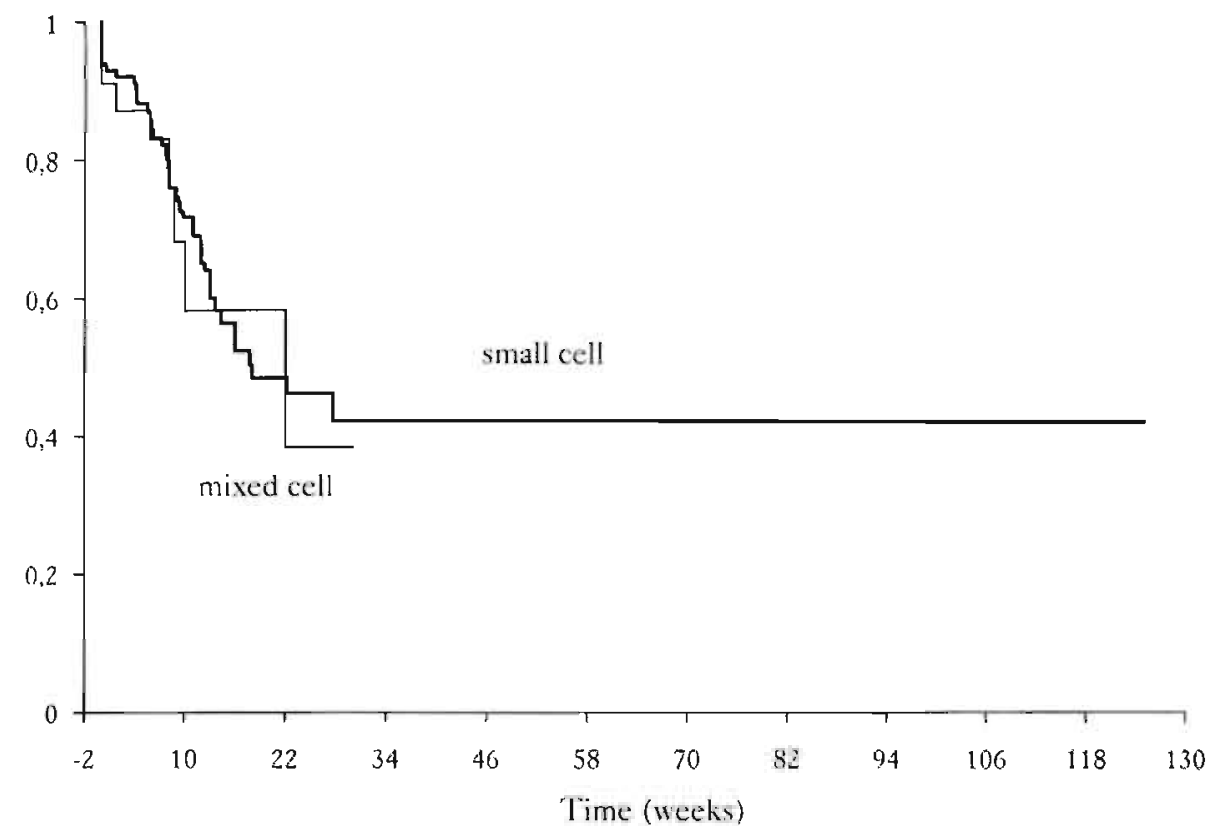

Figure 1. Kaplan-Meier curves of brain metastatic free survival for histologic subtypes.

were seen mostly in the smill cell type, buc this trend was noc significant $(p=0.15)$. The overall survival of patients with paraneoplastic syndromes was similar to that of orher parients.

\section{Discussion}

Small cell carcinoma of the lung is a malignant neoplasm with a highly aggressive behavior, resulting in early metastasis [17-19]. The prognosis of parients with SCLC has been improved by combination chemotherapy [20]. The presence of brain metastases is the most frequent neurologic complication in SCLC and is associated with poor prognosis. With a longer survival time these metastases have become an increasingly important clinical problem [21-22]. The SCLC is delineated from other entities in the neuroendocrine spectrum of pulmonary neoplasms. At the other end of the spectrum, with a low malignant potential, is carcinoid. In the grey area between SCLC and carcinoid, several proposals for nomenclature have been made [23-26]. The most simple subdivision would be (1) carcinoid, for the classic cases, (2) neuroendocrine carcinoma instead of arypical carcinoid, in view of its more malignant nature, and (3) SCLC. As yet this subdivision is not implemented in the last WHO classification [26]. Since our purpose was to investigate the clinical usefulness of the subclassification of SCLC proposed in the consensus report by the Parhology Commitree of the IASLC, we 
restricted this study to SCLC and excluded the other entities of the neuroendocrine spectrum. The IASLC recommendations were intended to provide a reproducible histopathologic subclassification of SCLC [16]. Since the introduction of this classification, much research has been done in evaluating the clinical behavior and response to therapy of SCLC and its subtypes. The interobserver agreement with regard to the diagnosis of the histologic subrypes was reasonable well in the scudy of Fraire et al. [10].

The frequencies with which the different subrypes were diagnosed in this study is slightly larger than those reported by Bepler et al. [8], Aisner et al. [9], and Fraire et al. [10]. This may be due to possible differences in sampling and biopsy size. Their studies suggested that the mixed cell type is as rare as the combined cell type and has a frequency of less than $5 \%$. The toral number of mixed and combined cell types is not at variance with these studies. Tumor heterogeneity has been proposed to be common and to be more frequent in larger biopsy specimens and posttherapy or obduction tissues [2,27,28]. According to Yesner et al. [28], the mixed cell rype is found more frequently in larger and less damaged biopsy specimens. In cases of tumor heterogeneity the use of small biopsies and cyrologic specimens in this study may have led to differenees in subtyping.
The results of this study do not show any statistically significant relacionship between histologic subryping and metastatic CNS pattern, developing brain metastases, or brain metastatic free survival. The number of neurologic paraneoplastic syndromes was similar to the $3 \%$ reported by Elrington et al. [29]. Because SCLC is delineated from other entities in the neuroendocrine spectrum of pulmonary neoplasms and the classic small cell lines are characterized by higher expression of neuroendocrine markers than the variant cell lines $[12,14]$, the assumption arises that the classic small cell subtype more frequently predisposes to paraneoplastic complications than mixed and combined subrypes. A slighr trend in line with this hypothesis was found in this study. Only the classic small cell subrype was encountered in patients with neurologic complications due to paraneoplastic syndromes. This tends to support the experimental research on SCL.C. Orher neurologic non-metastatic complications were not thought to be associated with histologic subtyping, but more likely to be treatment related or coincidental. Our neurologic data lack clinical significance with regard to histologic subtyping. This result supports the outcome of an earlier analysis of our patient population [11]. We conclude that histologic subtyping of SCLC has no implications for CNS metastases. However, the relationship with parancoplastic syndromes deserves further study: 


\section{References}

1. Osterlind K, thde DC, Ertinger DS er al: Staging and Prognostic Factors in Small Cell Cancer of the Lung. Cancer Trear Rep 67: 3-9, 1983.

2. Sheenan RG: Small Cell Lung Cancer: a Problem of Tumor Heterogeneity. Am J Med Sci 292: 241256, 1986.

3. Sehested M, Hirsch FR, Osterlind K, and Olsen JE: Morphologic Variations of Small Cell Lung Cancer: a Histopathologic Study of Pretreatment and Postreatment Specimens in 104 Patients. Cancer 57: 804-807, 1986.

4. Matthews MJ, and Gazdar AF: Pathology of Small Cell Carcinoma and irs Subrypes. A ClinicoPathologic Correlation. In: Lung Cancer I, R.B.Livingston RB (ed.) The Hague, The Netherlands, Nijhof pp241-268, 1981.

5. Hirsch FR, Osterlind K. Hansen HH: The Prognostic Significance of Histopathologic Subryping of Small Cell Carcinoma of the Lung according to the Classification of the World Health Organization. Cancer 52: 2144-2150, 1983.

6. Radice PA, Matthews MJ, Ihde DC, et al; The Clinical Behavior of "mixed" Small Cell/Large Cell Bronchogenic Carcinoma compared to "pure" Small Cell Subrypes. Cancer 50: 2894-2902, 1982.

7. Vollmer RT, Birch R, Ogden L, and Crissman JD: Subclassification of small cell lung cancer of the lung: the Southeastern Cancer Study Group experience. Human Pathol 16: 247-52, 1985.

8. Bepler G, Neumann K, Holle R, Havemann K, and Kalbfleisch H: Clinical Relerance of Histologic Subryping in Small Cell Lung Cancer. Cancer 64: 74-79, 1989.

9. Aisner SC, Finkelstein DM, Etringer DS, et al: The Clinical Significance of Variant-Morphology Small Cell Carcinoma of the Lung. J Clin Oncol 8: 402-408, 1990.
10. Fraire AE, Johnson EH, Yesner R, et al: Prognostic Significance of Histupathologic Subrype and Srage in Small Cell Lung Cancer. Hum Pathol 23: $520-528,1992$.

11. Twijnstra A, Thunnissen FBJM, Lassouw $G$, et al: The Role of the Histologic Subelassification of Tumor Cells in Patients with Small Celi Lung Carcinoma of the Lang and Central Nerwous Metastases. Cancer 65: 1812-1815, 1990).

12. Carney DN, Gazdar AF, Bepler G, er al: Establishment and identification of small cell lung cancer cell lines having classic and variant feamures. Cancer Res 45: 2913-23, 1985.

13. Carney DN, Mitchell JB, and Kinssella TJ: In vitro radiation and chemotherapy sensitivity of established cell lines of human small cell lung cancer and its large cell morphological variants. Cancer Res 43: 2806-2811, 1983.

14. Carney DN: Biology of small cell lung cancer. The Lancet 339: 843-846, 1992.

15. Yesnet R: Classification of Lung Gancer Histology. N Engl J Mled 312: 652-653, 1985.

16. Hirsch FR, Marrhews MJ, Aisner $S$, et al: Histopathologic Classification of Small Cell Lung Cancer: changing Concepts and Terminology. Cancer 62: 973-977, 1988.

17. Comis RL: Small cell carcinoma of the lung. Cancer Treat Rev 9: 237-258, 1982.

18. Choi NC, Carcy RW, Kaufman SD, Grillo HC, et al: Simall cell carcinoma of the lung: A progress reporr of 15 years' esperience.Cancer 59: 6-14, 1987.

19. Monte de la SM, Hutchins GM. Moore GW: Alrered metastaric behavior of small cell carcinoma of the lung after chemotherapy and radiation. Cancer 61:2176-2182. 1988.

20. Morstyn G, Ihde DC, Lichter A.S, et al: Small cell lung cancer 1973-1983: Early progress and 
recent obstacles. Int J Radiat Oncol Biol Phys 10:

515-539, 1984.

21. Sculier J, Feld R, Evans WK, et al: Neurologic disorders in patients with small cell lung cancer. Cancer 60: 2275-2283, 1987.

22. Tomlinson BE, Perry RH, Sieward-Wynne EG: Influence of site of origin of lung carcinomas on clinical presentation and central nervous system metastases. J Neurol Neurosurg Psychiarry 42: 82-88, 1979.

23. Paladugu RR, Benfiefd JR, Pak HY, et al: Bionchopulmonary Kulchizzky cell carcinomas: A new classification scheme for rypical and arypical carcinoids. Cancer 55: 1303-1311,1985.

24. Addis BJ, Hamid Q, Ibrahim NBN, et al: Immunohistochemical markers of small cell carcinoma and related neuroendocrine tumours of the lung. J Pathol 153: 137-150,1987.

25. Gould VE, Lee I, Warren WH:

Immunohistochemical evaluation of neuroendocrine cells and neoplasms of the lung. Pathol Res Pracr 183: 200-213, 1988 .

26. De Bruine AP, Bosman FT: Neuroendocrine tumours in the respiratory tract. Acta Histochemica Suppl band XXXVIII: 90-105, 1990.

27. Fraire AE, Roggli VL, Vollner RT, et al: Lung Cancer Heterogeneity: Prognostic Implicarions. Cancer 60:370-379, 1987.

28. Yesner R, Fraire AE. Zhang XB. er al: Thaditional Histology in the Diagnosis and Management of Small Cell Lung Cancer: Is it useful? Cancer Therapy Contiol 2:31-38, 1991.

29. Elrington GM, Murtay NMF, Spiro SG, NewsonDavis ]: Neurological paraneoplastic syndromes in parients with small cell lung cancer. A prospective survey of 150 patients. I Neurol Neurosurg Psychiatry 54: 764-767, 1991. 
Diagnostic value of CT in

the detection of brain meta-

stases in small cell lung

cancer patients 


\section{Introduction}

Small lung cell carcinoma (SCLC) constitutes $20 \%$ of all cases of lung cancer (1), and central nervous system (CNS) metastases are an important cause of morbidity and mortality among these patients (2). A simple two-stage division is customarily employed in SCLC. Limited disease (LD) is confined to the hemithorax of origin, the mediastinum and the supraclavicular nodes. In extensive disease (ED) tumor is found beyond these sites.

Staging procedures to detect possible sites of distant metastases are important, because of different forms of treatment are given to patients with limited and extensive disease (3).

\section{Current clinical methods of diagnosis of} brain metastases include physical examination and cranial computed tomography (CT). Brain metastases are found in approximately $10 \%$ of newly diagnosed patients (4). Most of these patients are sympromatic, and indicarion for specific diagnostic methods is determined by the symproms and signs $(5,6)$.

CT carried out as a part of routine inicial staging procedure in SCLC patients is not unanimously considered necessary, particularly when patients do not show neurological symproms. Therefore, this study was undertaken to determine the value of a routine cerebral imaging in SCLC parients in comparison to neurological findings.

\section{Patients and methods}

Between January 1985 and April 1990, 57 patients with SCLC were treated with chemotherapy according to a prospective protocol (7). The diagnosis of SCLC was based on histological and cytological biopsy. The subjects, 47 (89\%) males and 10 (11\%) females, ranged in age from $45-80$ (mean age 65). All patients underwent a neurological examination, a bedside mental status examination, a CT scan of the brain with and without contrast administration, and a bone scan. In the group of 57 patients 26 patients had LD, while 31 had ED. Three $(5 \%)$ of the 57 patients were excluded from this study; two of them had previous cerebrovascular infarces on C.T and one had leptomeningeal metastases at the time of presentacion. From January 1985 until February 1989, CT was performed with a Philips Tomoscan 350 , and from February 1989 until April 1990 with a Siemens Somaton Plus scanner.

Technical data of the Philips machine were; $120 \mathrm{kV}$, scan time $4.8 \mathrm{sec}, 180 \mathrm{mAs}$, slice thickness $9 \mathrm{~mm}$ and matrix $512 \times 512$. The images were recorded with a Philips multiformat camera. Technical data of the Siemens scanner were: $120 \mathrm{kV}$, scantime $2 \mathrm{sec}, 420 \mathrm{mAs}$, slice thickness $10 \mathrm{~mm}$ and matrix 512x512. Imaging was performed with a $3 \mathrm{M}$ laser printer. All scans were at first performed without contrast, and repeated after intravenous contrast injection. $100 \mathrm{ml}$ of Telebrix $350 \mathrm{mgl} / \mathrm{ml}$ was used mostly, while in cases with a his tory of allergy $100 \mathrm{ml}$ of Hexabrix 320 


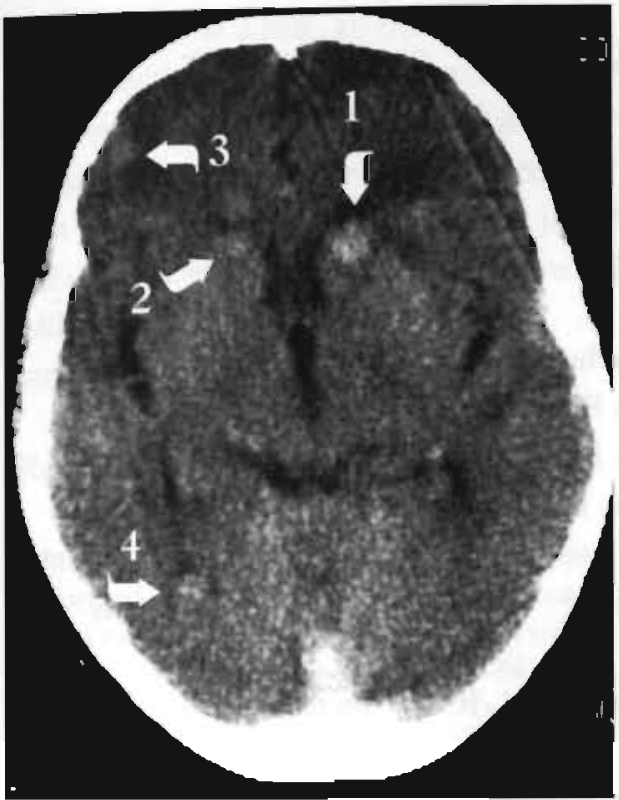

Figure 1. CT of the brain (third pacient in table 1). Shows an enhancing lesion in the head of the left caudate nucleus (arrow 1), smaller lesions faintley visualized arround right frontal horn (arrow 2), right frontal lateral cortex and at the tip of the right occipital horn (arrow 3 and 4).

$\mathrm{mgl} / \mathrm{ml}$ was injected. The window settings in which all scans were printed were: window width 100 Hounsfield Units (HU) and Center $40 \mathrm{HU}$. The CT findings were interpreted by a radiologist who had experience in cerebral CT scanning. Afterwards the CT scans were independently reviewed by neuroradiologist and a neurologist, and no discrepancies were found.

\section{Results}

Neurological symptoms and signs indica* ring metastasis were found in 4 parients out of $54(7 \%)$, see fig. 1. Three of these patients met the CT criteria for cerebral metastasis, and the abnormalities found in the neurological examination were anatomically consistent with the abnormalities on the CT scan, see table 1.

Bone scans revealed no abnormalities of the skull. One patient with neurological symptoms and signs showed no evidence of brain metastasis on CT. However, six monchs later, this parient's C'T scan indicated brain metastasis. In the remaining group of 50 neurologically asymptomatic SCLC patients no sign of cerebral netastasis was seen on CT.

\section{Discussion}

The value of routine cerebral cerebral scanning in SCiLC parients is controversial. The literature presents conflicting data on the question wherher patients without neurological symptoms should undergo CT of the brain. Levitañ et al. (8) found that in 3 out of $44(7 \%)$ SCLC patients with LD tumor, the stage was altered by the use of CT as a routine procedure. Crutz et al. (9) recommended routine $\mathrm{CT}$ scanning as part of the initial staging of parients with SCLC. He found that 6 neurologically asymptomatic parients out of $99(6 \%)$ parients with LD had been upstaged to ED. Butler et al. and Johnson et al. studied neurologically 
Patient nr, Classification gender, age

1. Male 75

2. Male 52

$\mathrm{ED}$

ED

- headache

-verrigo

presentation

- headache
Cranial C'T

single metastasis

multiple metastasis

- vision R eye I

- prosis R eye

- paresis R leg

multiple metastasis
- headache
3. Female 69
ED
- papilledema $L / R$
no metastasis
- vision L/R
4. Male, 59
ED

Table 1. Sympromatic patiens with SCLC and frequences of brain metastasis; ED: extensive disease; $\mathrm{L}=\mathrm{left} ; \mathrm{R}=\mathrm{right} ; \mathrm{SCLC}=$ small cell lung cancer; $\mathrm{CT}-$ computer tomography.

intaet SCLC patients and found brain metastases in three out of $55(5.5 \%)$ and two out of $84(2 \%)$, respectively. Both authors conclude that rourine cerebral imaging is advisable in these parients.

Because of the low incidence of CNS metastases at the rime of diagnosis in asymptomatic SCLC parients, we doubred the benefit of routine cranial CT. In our study $4(7 \%)$ of the 54 SCLC patients showed evidence of neurological symptoms and signs, which was confirmed in 3 patients with CT. In one symptomaric patient no brain metastasis was found on the (:l' stan at the time of presentation. Howcer, six months later CT indicated brain metastasis. We believe that C'l was not sensitive enough in this patient to detect the initial small lesions. In such cases we would suggest MRI which is superior in detecting subrle lesions $(10,11)$.

Although plain MRI carries the risk of false positive interpretation of non-neoplastic age-related parenchymal lesions in the elderly (10.11), contrast enhanced MRI using gadolinium DTPA can differentiate between areas of altered signal intensity due to widening of the perivascular spaces and areas containing me tastases (12). It appears likely that contrast enlanced YIRI will become the method of choice for detection of cerebral metastasis. 
In our study, as a rule, all SCI.C patients were examined by a neurologist, and no brain metastases were discovered in neurologically normal patients. We conclude that CT scanning of the brain at the initial stage of SCLC does not contribute additional diagnostic information to a careful neurological examination.

\section{References}

1. Matchews M.J., Gordon P.R. Morphology of pulmonary and pleural malignancies. In: Lung cancer clinical diagnosis and treatment. Straus M.J. (ed). Grune \& Stratton, Philadelphia, 1988, 63-84.

2. Sculicr J.P., Feld R., Evans W.K. et al. Neurologic disorders in patients with small cell lung cancer. Cancer 60: 2275-2283, 1987.

3. Osterlind K. Prognostic factors in small cell lung cancer: an analysis of 874 consecutive parients. In: Lung cancer: basic and clinical aspects. Hanssen H.H. (cd). Martinus Nijhoff, Boston, 1986.

4. Komaki R. Cox J.D., Whirson W. Risk of brain metastasis for small cell carcinoma of the lung related to length to survival and prophylactic irradiation. Cancer Trear Rep 64: 957-961, 1980.

5. Butler A.R., Jin S.L. Jip J.P., Boyd A.D., Kircheff I.I. The value of routine cranial computed tomography in neurologically intact patients with primary carcinoma of the lung. Radiology 131: 399-401, 1979.

\begin{abstract}
6. Johnsen D.H., Windhan W.W. Allen J.H. Limited value of C.T brain scans in staging of small cell lung cancer. AJR 140:37-40, 1983.
\end{abstract}

7. Twijnstra A., Boon P.J., Lormans A.C., Ten Velde G.P. Neuroroxicity of prophy̧lactic cranial irradiation in patients with small cell carcinoma of the lung. Eur J Cancer Clin Oncol 23: 983-986, 1987.

8. Levitan N., Hong W.K., Byrne R.E., Gale M.E,
Bromer R.H., Levine H.L., Licciardello J.T., and Abbruzzese 1.L. Role of computerised cranial tomography in staging of small cell carcinoma of the lung. Cances Treat Rev 68: 1375-1377, 9984.

9. Cruz J.M., Jackson D.V. Jr, Muss H.B., Spurr C.L., Capizzi R. L. Detection of brain metastasis and diagnosis of small cell carcinoma of the lung. J

Neurooncol 2: 67-71, 1984.

10. Jellinek J., Smimiotopoulos J.G., Parisi J.E., Kanzer M. The brain: differential diagnosis based on clinical, CT, and MR findings. AINR 11: 567-574, 1990; AJR 155: 365-372, 1990.

11. Lee Y.-Y., Tien R.D., Bruner J.M., De Perra C.A. Van Tassel P. Loculated intracranial lepromeningeal merastases: CT and MR characteristics. AJNR 10: 1171-1179, 1989; AJR 154: 351-359, 1990.

\section{2:. Russefl E.J., Geremia G.K., Johnson C.E.}

Multiple cerebral metastases: detectability with GdDTPA-enhanced MR imaging. Radiology 165: 609617, 1987. 


\section{Diagnostic value of MR ima-}

ging in the detection of

brain metastases at initial

staging in small cell lung

cancer 


\section{Introduction}

Small cell lung carcinoma (SCLC), which accounts for approximately 25 per cent of the cases of lung cancer, has a highly aggressive behavior, resulting in early metastasis [1]. The prognosis of patients with SCLC has improved with chemorherapy [2]. The occurrence of brain metastases is the most frequent neurological complication in SCLC, and is associated with a poor prognosis $[3,4]$.

Prior to the advent of magnetic resonance (MR) imaging, neurological examination and cranial computed tomography (CT) were used as screening procedures for brain metastases [5-8]. More recently, the use of a contrast agent such as gadolinium DTPA has extended the role of MR imaging in the evaluation of brain metastasis and making MR imaging superior in sensitivity and specificity to the CT-scan for the detection of brain metastasis $[9,10]$.

The value of MR imaging of the brain as a screening procedure in patients with SCLC has nor been adequarely studied. To assess the value of routine MR imaging in the staging work-up of patients with small cell lung cancer, we studied the correlation of MR findings with the neurological examination in 40 patients with small cell lung cancer.

\section{Patients and methods}

\section{Subjects}

Berween May 1991 and March 1994, 40 parients with newly diagnosed SCLC were included in the study. The diagnosis of SCLC was based on histological or cytological biopsy. To detect areas of distant metastases, ultrasound and CT of the abdomen, radionuclide bone scan, MR bone scan and bone marrow aspirates were routinely performed. Limited disease (LD) was defined as tumor confined to one hemithorax with or without ipsilateral mediastinal or supraclavicular lymph node involvement. Patients with extrathoracic tumor spread beyond these sites were classified as having extensive disease (ED).

\section{Treatment and clinical assessment}

In the course of evaluation, all parients were rourinely referred to the department of neurology for an assessment of possible neurological metastases. All patients underwent a neurological examination. Patients were prospecrively evaluated by a neurologist every three months for the first year, and biannually thereafter. Follow-up cranial MR scans were performed on indication only. The patients were followed until dearh or for at least three months.

\section{MR imaging}

MR imaging of the brain was performed within one month (in $85 \%$ of the patients 
within two weeks) after the parhological confirmation of SCLC. MR imaging was perfomed with a $0.5 \mathrm{~T}$ system (Philips Gyroscan II). First a set of transwerse T2 weighted images was obrained. In the first 38 examinations a conventional spinecho sequence (TR 3-3.5 seconds, TE $120 \mathrm{msec}$ FOV $230 \mathrm{~mm}, 5 \mathrm{~mm}$ slices 205×256 marrix, NSA1) was used. All later examinations featured a fast spin-echo sequence (TR 4.5-6.5 sec, TE $130 \mathrm{msec}$, FOV $2.30 \mathrm{~mm}, 241 \times 256$ matrix, NSA4, echo train length 16$)$. T1-weighted spinecho images were obtained (TR 600 msec, TE $18 \mathrm{msec}$ FOV $230 \mathrm{~mm}, 10 \mathrm{~mm}$ slices $205 \times 256$ matrix, NSA4) before and after IV injection of the MR contrast medium gadolinium DTPA (MagnevistR) in a dosage of $0.1 \mathrm{mmol} / \mathrm{kg}$.

MR findings were classificd into four groups according to Elster [11]:1) norma] scans; 2) scans with unequivocally benign lesions (infarctions, arachnoid cysts etc.) that harboured no suspicion of metastatic disease; 3) scans with at least one enhancing lesion comparible with a metastasis; and 4) scans with one or more hyperintensities of the deep and subcortical white matter and periventricular hyperincensiries, none of which enhanced after contrast injection.

The MR findings were interpreted by a neuroradiologist (JTW) with extensive experience in cerebral MR and were later blindly reviewed by the same neuroradiologist together with a neurologist (AT) No discrepancies were found between the first and second assessments.

\section{Results}

\section{Forty patients had both a neurological} examinatioñ and an MR examinarion .

Motion artefacts occurring in one agitated patient led to premature termination of the MR examination. This patient was excluded from the study population. Of the remaining 39 patients, 15 patients were staged by the pulmonologist as having limited disease, while 24 parients were staged as having extensive disease. The parients, 30 males and 9 females, ranged in age from $31-78$ years (median age 62).

The MR findings are summarized in table 1 . Of the 12 parients $(31 \%)$ with normal MR examination (group 1), one parient with a history of chronic headache and transienr ischemic attacks had recently developed difficulties with concentracion. Clinical follow-up revealed no signs of brain metastases.

At the time of the MR imaging study, two parients $(5 \%)$ with previously documenred cerebrovascular diseases from group ?(benign lesions) had non-enhancing white marter lesions, which where confidently interpreted as non-metastatic.

Eleven patients (28\%) had MR results which were interpreted as positive for tumor metastases (group 3). The neurologic deficits derected by neurologic examination were anatomically consistent with the MR findings. Three ED parients had asymptomatic brain metastases. 


\begin{tabular}{llll} 
& & abnormal/normal & within 6 months \\
\hline group 1 & 12 & $1 / 11$ & 0 \\
group 2 & 2 & $2 / 0$ & 0 \\
group 3 & 11 & $8 / 3$ & 11 \\
group 4 & 14 & $4 / 10$ & 2 \\
\hline
\end{tabular}

Table 1. Magnetic resonance imaging and clinical findings in 39 parients with small cell lung cancer. Magnetic resonance imaging (MRI) findings were classified inco four groups: group $1=$ normal: group 2 = benign lesions ( $($ wo patients with cerebral infarctions); group $3=$ metastasases (three parients wert: isymptomaric); group $4=$ non-enhancing white matter lesions (two of the four symptomatic parients developed brain metastases within six months, one patient after ten months).

Of the 8 neurologically symptomatic patients, 3 had no other signs of extrathoracic tumor activity and were initially classified by the pulmonolugist as having limited disease. The classification was later changed to extensive disease on the basis of neurological consultation and MR findings.

Four of $1+$ pacients (36\%) from group 4 (non-enhancing white marrer lesions) had neurologic svmptoms and signs but showed no MR cridence of brain me tastascs. One patient with a brief history of frontal headache and atypical brachialgy at inirial neurologic examination, did nor develop brain metastases and turned out to have tension headache and a carpal tunnel syndrome. However, 3 of the 4 sympromatic patients were found to have developed brain metastascis by follow-up MR imaying. The MR scan of the first patient demonstrated enhancing brain metastases two months later, with a rapidly progressive decline. The second patient, with left sided facial weakness and hyperreflexia of the left arm, developed an unstable gait and became progressively confused three months lacer. Then months after initial staging, the third patient, with a brief history of atypical pain, developed signs of raised intracranial pressure and cerebellar ataxia. As shown in figure 1, some of the initially nonenhancing white matter hyperintensitics increased in volume and showed contrastenhancement at follow-up examination. 

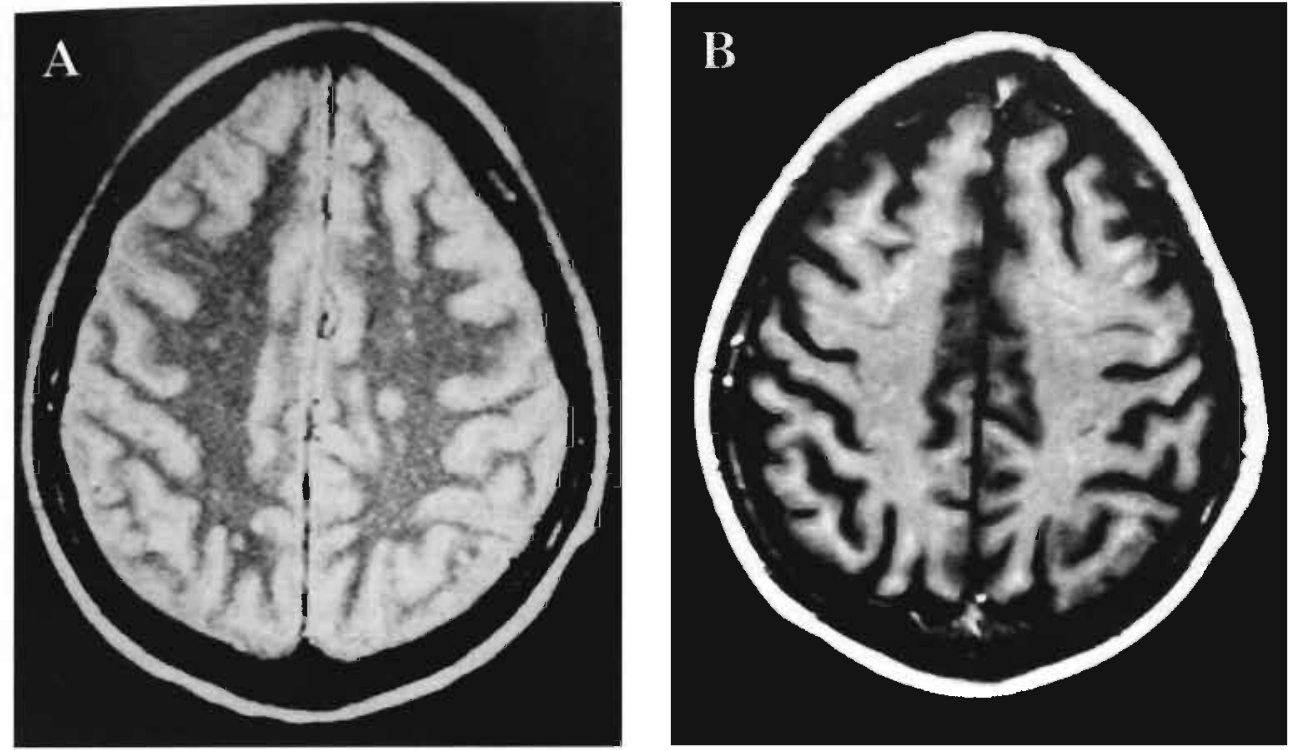

Figure 1. Magnetic resonance imaging of the brain in a 51-year old parient with neurological abnormalities at initial staging.

Figures $\mathrm{A}$ and $\mathrm{B}$ werc obtained before treatment, figures $\mathrm{C}$ and $\mathrm{D}$ after neurological deteriorarion three months later; A T2-weighted image shows deep white matter hyperintensities; B T1-

weighted image after Gd-D'lPA injection do not show enhancement; C T2-weighted image once again shows deep white matcer hyperintensities; D T1-weighted image after Gd-DTPA injecrion shows obvious contrast-enhancement.
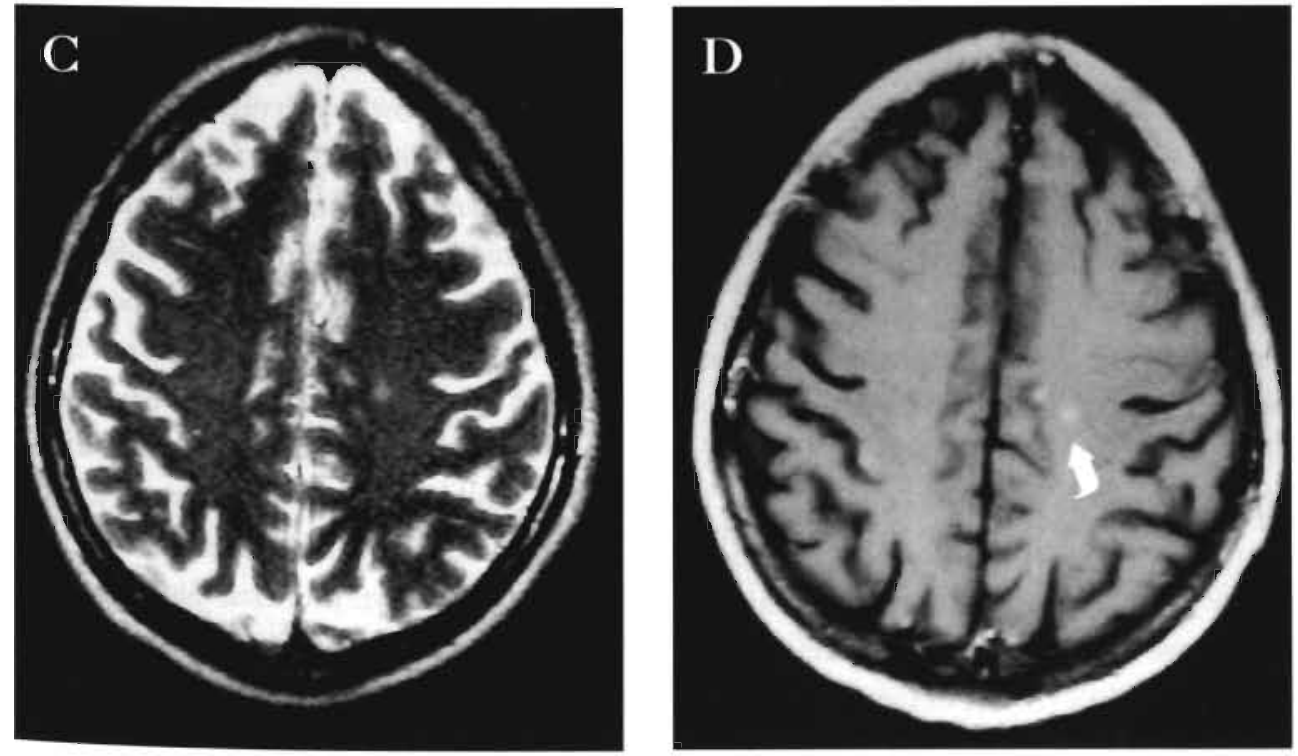


\section{Discussion}

The major goals of staging patients with SCLC are to provide prognostic information and to select the best treatment. The value of routine cerebral imaging in SCLC patients is controversial, because CT has failed to detect some metastases, especially those which are in the posterior fossa. The literature presents conflicting data on the question whether patients without neurological symptoms and signs should undergo CT of the brain [6,7]. We have found that CT is not sensitive enough in asymptomatic patients and need therefore not be a part of the routine staging procedure in small cell lung cancer $|8|$.

The advene of magnetic resonance imaging has had a profound effece on the evaluation of central nervous system (CNS) tumors; it offers marked advantages over CT and provides superior definition of a CNS tumor, particularly if a paramagnetic contrast agent is used. Contrast CT and non-contrast MR imaging are roughly comparable in the detecrion of brain metastases. Post-contrast MR imaging, however, have an increased accuracy, compared with contrast-enhanced CT, particularly in the detection of metastases in the posterior fossa and cortex $(9,12)$. The value of contrast-enhanced MR imaging of the brain at initial staging in parients with SCLC has not been studied in the past. In the present study, brain metastases were found in 11 patients of the 39 patients (28\%), depicted as con- trast-enhancing lesions on initial MR imaging. Prior CT studies have demonstrated a 5 to $27 \%$ incidence of brain metastases at diagnosis of SCLC [5-8]. Magnetic resonance imaging revealed brain metastases in three neurologically asymptomatic patients in our study. However, these discrepancies did not affect the clinical staging, as the patients concerned were already known to have extensive disease on base of other extrathoracic metastases.

In the present study, non-enhancing white matter lesions were seen in 14 patients. Four of these patients were neurologically symptomatic and in three of them, the initially non-enhancing white matter lesions later changed into contrastenhancing lesions, compatible with brain metastases. It therefore appears that conrrast-enhanced MR imaging may under report some early metastases, which are obscured from view by high-signal white matter lesions on $\mathrm{T} 2$-weighted images and do not yet show contrast-enhancement on T1-weighted images.

Early investigators observed that MR imaging brings to light a high frequency of white matter abnormalities that cannot be related to clinical findings and could not previously be detected (13-15). These appear as bright areas on boch proton density and T2-weighed images. Their sizes range from small foci to large confluent lesions, and they vary in extent and location. White matter hyperintensities in neurologically asymptomatic patients vary in frequency from $11 \%$ in the fourch decade to $65 \%$ in the seventh decade [14]. 
Fazekas et al found that deep white matter hyperintensities reflect increasing severity of ischemic tissue damage, the most likely substrate of white matter hyperintensities in elderly patients [15].

Some investigators have assumed that lesions of the subcortical, deep and periventricular white matter on $\mathrm{T} 2$-weighted images were not brain metastases if they did not enhance with contrast agent used in combination with $\mathrm{T} 1$-weighted images $(9,10)$. Elster et al found that white matter lesions in cancer patients which not enhance with Gadolinium-DTPA at the time of the initial MR study had a low probability of representing metastatic disease and suggested that in questionable cases, follow-up scans should help to differentiate them from metastases (11). Our findings, however, showed that initially non-enhancing white matter lesions can develop into brain metastases. The earliesc MR manifestation of metastatic disease in the brain is not known. It is unclear whether this earliest manifestation of metastatic disease is contrast enhancement or a high signal $\mathrm{T} 2$ abnormality, reflecting increased rissue warer content rather than contrast accumulation.

In conclusion, MR imaging is a sensirive tool in the detection of brain metastases at initial staging of SCLC-patients, since brain metastases werc visualized in three neurologically asymptomatic parients.

The combination of MR imaging and clinical findings is of value in preventing false-negative diagnosis. When cerebral metastases are suspected on elinical grounds and MR imaging shows only nonenhancing white matter lesions, the best course of action would be to perform neurological and neuroradiological follow-up.

\section{References}

1. Vailler J, Ihde DC. Small cell carcinoma of the lung: Clinical and biologic aspects. Crirical reviews in Oncology/Hemstology 11: 109-135, 1991.

2. Hansen HH. Management of small-cell lung cancer of the lung. The Lancet 339: 846-849, 1992.

3. Pedersen AG. Diagnostic procedures in the detecrion of CNS metastases from small cell lung cancer. In: Hanssen H.H. editor. Lung cancer: basic and clinical aspects. Boston: Marrinus Nijhoff: 153-182. 1986.

4. Sculier JP, Feld R, Evans WK, Debeer (, Sheperd FA. Payne DG, et al. Neurologic disorders in patients with small well lung cancer. Cancer b0: $2275-2283,1987$.

5. Cruz JM, Jackson DV Jr, Muss HB, Spurr CL. Capizzi RL. Dececrion of brain metastasis at diagnosis of small cell carcinoma of the lung. I Neurooncol 2: $67-71,1984$.

6. Leviran N. Hong WK, Byme RE, Gale ME, Bromer RH. Levine HL, et al. Role of computerized cranial tomography in the staging of small cell carcinoma of the lung. Cancer Treat Rep 68:1375-1377, 1984.

7. Jahrison DH, Windham WW, Allen JH, Greca FA. Limited value of C.T brain scans in the staging of small cell lung cancer. Am J Roentgenol 140: 37-40. 1983.

8. Habets JM, van Oosterhour AG. ten Velde GP", Wilmink JT, Twijnstra A. Diagnostic value of $\mathrm{CT}$ in the detecrion of brain me rastasis in small cell lung 
9. Sze G, Milano E, Johnson C, Heier L. Detection of brain metastases: comparison of contrast-enhanced MR with unenhanced MR and enhanced CT. Am J Neuroradiol 11: 785-791, 1990.

10. Russell EJ, Geremia GK, Johnson CE, Huckman MS, Ramsey RG, Washburn Bleck J, et al. Multiple cerebral metastases: Detectability with Gd-DTPAenhanced MR imaging. Radiology 165: 609-617, 1987.

11. Elster AD, Chen MYM. Can nonenhancing white matter lesions in cancer patients be disregarded?

A.J.N.R. 13: 1309-1315, 1992.

12. Davis PC, Hudgins PA, Peterman SB, Hoffman jr. JC. Diagnosis of cerebral metastases: Double-dose delayed CT vs contrast-enhanced MR imaging.

A.J.N.R. 12: 293-300, 1991.

13. Yerkin FZ, Haughton VM, Fischer ME, Papke RA, Daniels DL, Mark LP, et al. High-signal foci on MR images of the brain: observer variability in their quantification. A.J.R. 159: 185-188,1992.

14. Fazekas F. Magnetic resonance signal abnormalities in asymptomatic individuals: Their incidence and functional correlates. Eur. Neurol 29: 164-168, 1989.

15. Fazekas F, Kleinert R, Offenbach H, et al. The morphologic correlate of punctate white mater hyperintensities on MR images. A.J.R. 157: 1317 $1323,1991$. 


\section{Efficacy and safety of pro-}

phylactic cranial irradiation

in 203 consecutive patients

with small cell lung

carcinoma 


\section{Introduction}

Brain metastasis is a well recognised complication in small cell lung cancer (SCLC). Approximately $0-16 \%$ of the patients have brain metastases at initial diagnosis, 0-32\% subsequently develop brain metastases during treatment, and $28.64 \%$ have brain metastases in various post-mortem studies [1]. The risk of brain metastasis increases with lengthening survival, to a cumulative risk of $80 \%$ in parients at 2 years after diagnosis [2]. Though combination chemotherapy with or without locoregional radiotherapy has yielded complete or partial responses in $80-90 \%$ of all patients, median survival is limited to 11-16 months depending on the initial tumor stage [3]. Prophylactic cranial irradiation (PCI) is effective in reducing the central nervous system (CNS) relapse rate [4].

- lowever to date, no randomized trial showed any PCI survival benefic [4]. And its use has become controversial as $\mathrm{PCl}$ porentially contributed to CNS-toxicity in SCLC patients [4-10, 16]. PCI failure with regard to survival is probably explained in that CNS relapse in the majority of the parients is associated with recurrence or progression of systemic disease. The CNS as sole site of relapse is only seen in $3-4 \%$ of the patients [11]. However, PCI administration becomes interesting again with the development of new treatment protocols with increased median survival time and increased 2 year survival rate |12-1+].
In this study, we present the results of a neurologic follow-up of a cohort of 203 consecutive patients with SCLC. The efficacy of PCI is analysed for limited stage patients who achieved complete remission, whereas all parients given $\mathrm{PCl}$ are evaluated for possible adverse effects of PCI. Furthermore the neurologic condition of 18 patients who survived the diagnosis of SCLC for more than 2 years is described in detail.

\section{Patients and Methods}

From January 1983 to January 1993, 203 consecutive patients with histologically proven SCLC were included in this prospective study. Minimal follow up was 1 year or until dearh, till January 1994. Initial staging of these patients by a pulmonologist, was based on physical examination, standard blood and chemistry profile, chest X-ray, CT-scan of the chest, ultra-sound of the abdomen, radionuclide bone scan, fibre optic bronchoscopy, and bone marrow aspirate and biopsy. Limired disease (LD) was defined as tumor confined to the ipsilateral hemithorax, the mediastinum, and the ipsilateral and/or contralateral scalene and supraclavicular lymph nodes. In extensive disease (ED) tumor was found beyond these site.

\section{Patients were seen by a neurologist at} diagnosis and at quarterly intervals (biannually after a year). A CT-scan of the brain, MR imaging after 1991, was performed before treatment. 
More frequent neurologic consultations and other auxiliary diagnostic tests were done if required. In patients with a longrerm survival (defined as 2 years or longer from diagnosis) an additional CT- or MRscan of the brain was performed. Central nervous system abnormalities found in patients treated with PCI, were designated as possibly treatment related unless otherwise clearly explainable.

All patients were initially treated with a combination chemotherapy regimen, consisting of cyclophosphamide $1000 \mathrm{mg} / \mathrm{m} 2$, doxorubricin 45 or $50 \mathrm{mg} / \mathrm{m} 2$, and etoposide $100 \mathrm{mg} / \mathrm{m} 2$ on day 1,3 , and 5 for at least five cycles. Chemotherapy was sometimes followed by radiorherapy to the primary tumor site. Restaging was performed after five courses of chemotherapy and consisted of physical and radiological examinations, fibre opric bronchoscopy, and those examinations which were abnormal at the initial staging procedure; complete remission (CR) was defined as a total resolution of all detectable lesions.

Only: patients who obtained CR were candidates for treatment with PCI. Till 1986 LD and ED parients could opt for PCI, after 1486 LD parients only. Parients were treated with a linear accelerator, usually $6 \mathrm{MV}$ photons, using two lateral opposed fields. The dosic was calculated in the midline, and delivered in daily fractions of 3 Gy, 4 times a week up to a total dose of $30 \mathrm{~Gy}$. During 1988 - 1990 the radiation technique was changed as the fraction dose was lowered to $2 \mathrm{~Gy}, 5$ frac- tions a week up to a total dose of $30 \mathrm{~Gy}$. In 1990 PCI was excluded from the treatment protocol. Between 1983 and 1990, two eligible LD parients refused PCI. Patient characteristics and treatment specifications are listed in table 1.

The efficacy of PCI was analyzed for LD patients with CR only. Statistical significance of the incidence of brain metastasis was calculated with the Fisher's exact test, of the survival curves with the $\log$ rank test. Overall survival was calculated from SCLC diagnosis to death or end of observation period, brain metastatic free survival from SCLC diagnosis to the diagnosis of brain merastases or end of observation period. The safery of $\mathrm{PCI}$ was evaluated for all patients who achieved CR and were treated with PCI. The neurological condition of the long-term survivors (defined as 2 years or longer from diagnosis) is described in detail, in particular with regard to adverse reactions of PCI. 
total

men / women

median age at diagnosis (range)

complete remission

prophylactic cranial irradiation

\section{4}

$59 / 15$

$64(39-84)$

37

17
$111 / 18$

$65(45-89)$

30

5

Table 1. Patient characteristics.

\section{Results}

\section{Efficacy of PCI}

Efficacy of PCI was assessed in $37 \mathrm{LD}$ parients who achieved CR. Brain metastases were diagnosed in 3 of 17 parients treated with PCI versus 8 of 20 parients not treated with PCI. The number of brain metastases did not differ significantly $(p=0.26)$. The brain metastatic free survival curves are shown in figure 1 , and the overall survival curves in figure 2. For the analysis of the survival curves lepromeningeal metastases were considered as brain metastases for statistical reasons; two of the 5 patients with brain metastasis after PCI actually had leptomeningeal metastases. Log rank analysis of survival curves revealed significant differences between patients with and without PCI. Patients treated with PCI had a longer brain metastatic free survival $(p=0.012)$ as well as a longer overall survival $(p=0.004)$ than patients not treated with PCI. The majority of the patients ( 30 patients or $81 \%$ ) had an intrathoracic SCLC recurrence, see table 2. Brain metastases were diagnosed after systemic recurrence of the disease in 7 parients. Systemic recurrence was established within 1 month after the diagnosis of brain metastases in 3 other patients. The brain as sole site of relapse was seen in 1 patient who was treated with PCI. New malignancies [ 1 nonSCLC and 1 Non Hodgkin Lymphoma] were diagnosed in 2 patients. Only 3 parients ( $8 \%$ ) had no relapse. The exacr cause of dearh remained unknown in 1 patient.

\section{Safety of PCI}

Safery of PCI was assessed in $17 \mathrm{LD}$ and 5 ED patients treated with PCI between 1983 and 1990. Early neurologic sequelae were seen till three months after PCI; 7 of the 22 parients experienced headache and nausea during PCI, another 5 patients reported with a brief period of increased riredness. 


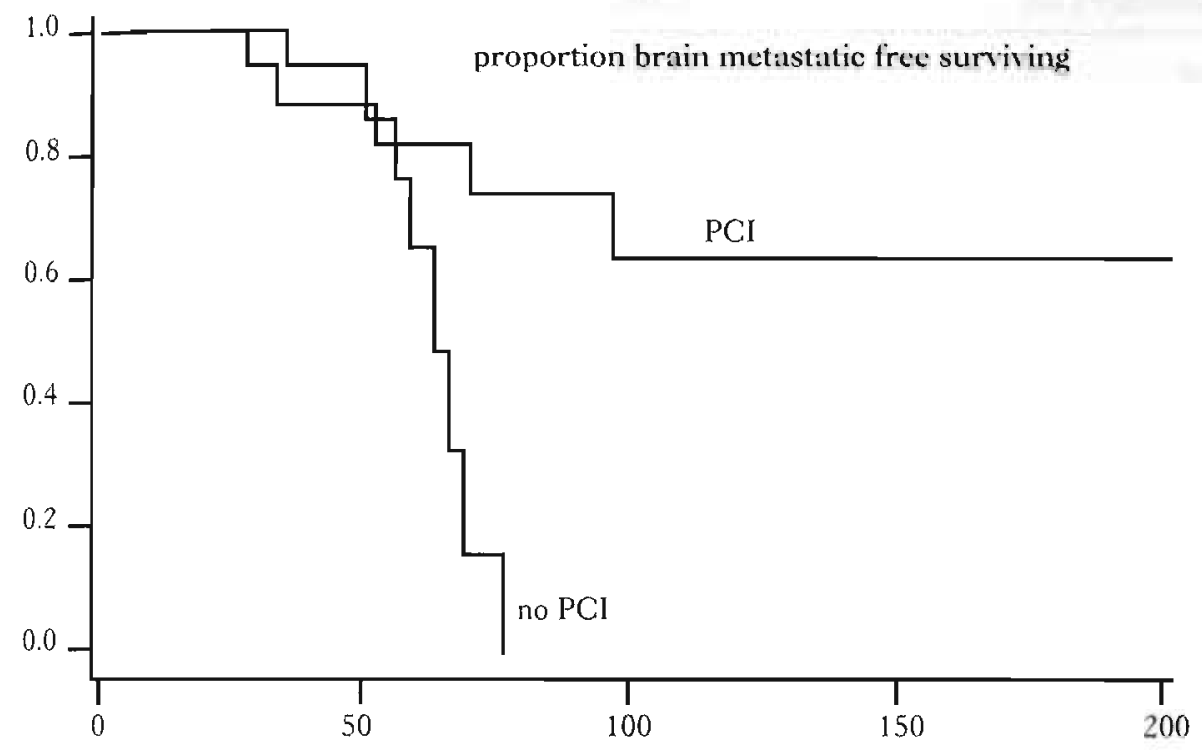

Figure 1. Brain metastatic free survival in weeks: 6 patiens in PCI group were still at risk past 200 weeks.

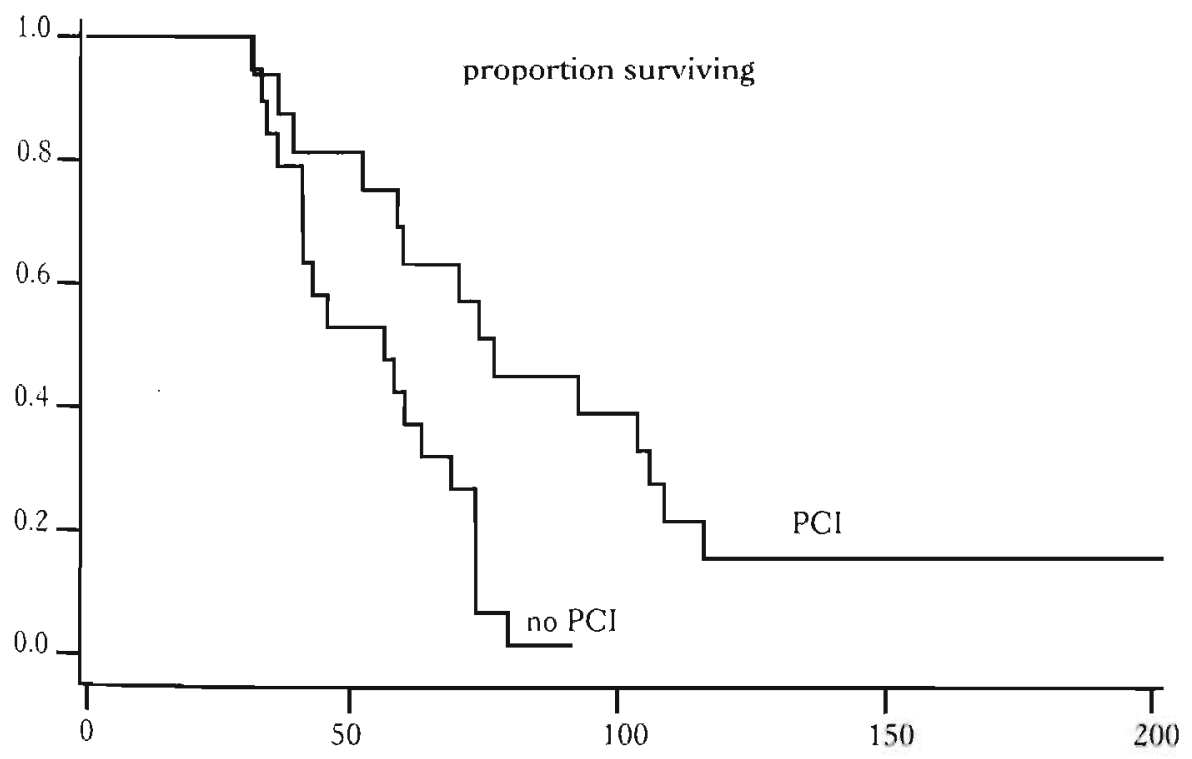

Figure 2. Overall survival in weeks: 1 parient in PCI group passed away at 417 weeks, 1 is still at risk. 
total

median age (range)

radiotherapy primary tumor

median survival (range)

Relapse

lung

6

lung and CNS

sole CNS

new malignicy

none

unknown
17

20

$56(42-78)$

$68(48-84)$

6

5

$18(7-132)$

$13(7-19)$

Table 2.Outcome of 37 limited disease patients with complete remission.

Age is in years and survival in months; $\mathrm{PCl}=$ prophylactic cranial irradiation:

CNS = central nervous system: 2 of these patients had leptomeningeal metastases.

Of rhe original group of 203 patients 18 patients $(9 \%)$ survived for more than two years. Their neurologic outcome is presented in table 3. Four patients, all not treated with PCI remained without neurologic complications. Possible treatment related neurologic complications arose in 7 patients with PCI and 1 patient without PCI. Orher, non trearment related, neurologic complications comprised brain merastases in 3 parients, cerebrovascular accident in 2 patients, and paraneoplastic subacute cerebellar degeneration in 1 patient.
Memory disturbances surfaced as the most frequent possible treatment related complication in 8 patients ( 7 with and 1 without PCI). Immediate recall was usually affected. The memory decline was insidious and started in 6 patients within 6 months after termination of therapy and in 2 other patients after 18 months. Once established the memory disturbances remained stable for months to years in most of the patients. Memory disturbances were accompanied by lechargy or a generalised lack of energy in 4 parients. Although the lethargy, in these patients, started simultaneously with the memory 


\begin{tabular}{lll} 
Patients & PCI & no PCI \\
\hline rotal & 9 & 9 \\
men/women & $7 / 2$ & $6 / 3$ \\
median age at diagnosis (range) & $55(52-67)$ & $60(45-74)$ \\
median survival (range) & $40(25-120)$ & $27(24-56)$ \\
Ncurologic complications & & \\
none & 0 & 4 \\
possible & 7 & 1 \\
other & 2 & 4 \\
Radiologic abnormalities & & 2 \\
none & 2 & 3 \\
possible treatment related & 5 & 4 \\
other & 2 & \\
\hline
\end{tabular}

Table 3. Neurologic outcome of long-term survivors.

A divided over three catcgories, with no, possible treatment related, and orherwise explainable neurolıgic complications or radiologic abnormaliries, respectively.

disturbances, the course was more unpredictable; two patients improved and two patients developed a progressive aparhy combined with drowsiness, in one of them resulting in a full blown demencia syndrome.

In 3 of 9 patients without PCI, possible treatment related radiologic abnormalitics were manifest; 1 patient with memory disturbances had aspecific white matter lesions, and in 2 other parients though neurologically normal brain atrophy was present.

Of 9 patients receiving PCI treatment 5 had possible treatment related radiologic abnormalicies. These 5 are broken down as follows: 1 parienr suffering from memory disturbances, developed visual complaints 7 years post treatment. The complaints consisted of distortions and discolorations in her visual field. 
Togerher with the visual complaints her walk became unstable. Brain MR scan showed aspecific white marter lesions right sided parieto-occipital but was otherwise normal. Two patients (one with memory disturbances and another with memory disturbances and non progressive lethargy) had brain atrophy, and finally 2 parients (with memory disturbances and progressive lethargy) manifested brain atrophy as well as periventricular white matter lesions. normal follow-up scans. Ourside of these 5 patients, 2 PCI patients had possible treatment related neurologic complications (one with memory disturbances and anorher with memory disturbances and non progressive lethargy) and normal follow-up scans.

Of the 8 long-term survivors with possible treatment related neurologic abnormalities 5 ( 4 with and 1 without $\mathrm{PCI}$ ) experienced minor neurologic deficits (memory disturbances), and 3 were seriously handicapped by these deficits (2 patients with a progressive lechargy, and 1 patient with visual complaints and an unstable gair). All other patients were capable of basic self care and resumed a lifesryle more or less similar to that before diagnosis of SCLC. Some patients concluded their working life earlier, because of impaired physical rather than neurological condition.

\section{Discussion}

An analysis of 9 randomized trials by Pedersen er al [4] revealed a reduction of the accumulated frequency of clinical brain metastases from 23\% wirhout PCI to $6 \%$ with $\mathrm{PCI}$, but no improvement in overall survival. The total population of 716 parients in this analysis was rather heterogeneous as some studies included patients who did not achieve CR, and patients with ED. Furthermore these studies were, as far as reported, different with regard to the follow-up rime. Rosen et al [15] demonstrated an increased survival with $\mathrm{PCI}$ in patients responding completely. Fleck et al [16] analysed 58 LD patients who went into CR and found significantly fewer overall C.NS relapses in patients treated with PCI, though the difference berween initial CNS relapses was small and the disease-free survival, and overall survival did not differ significantly. PCI appears to have been effective in increasing survival of LD patients who achieved durable thoracic control in a study by Rosenstein et al [17]. In the present neurologic follow-up study, PCI had no impact on the frequency of brain metastases whereas the brain merastaric free survival and overall survival improved significantly. Howerer, these results should be interpreced carefully as the number of paciencs is suadl] and it is a non-randomicd study. Locoregional treatment differed slighty in parients treated with and withour PCI. Racliorherapy to the primary tumor was administered to 6 of the 17 parients treated with PCI (35\%) and 5 
of the 20 patients not treated with PCI $(25 \%)$.

Hirsch et al [18] showed that $33 \%$ of the patients had "silent" brain metastases, in a study in which clinical and autopsy findings were compared. In rhis study, the clinical diagnosis of brain metastases became more reliable by regular neurologic examinations and the use of modern imaging techniques, although it remained clinically difficult to establish the extent to which metastases are restricted to the CNS. Isolated CNS metastases can represent seeding from a previously undetected intrathoracic relapse. In the present study, a sole CNS relapse was seen in 1 patient treated with PCI only. The majority of the patients had a systemic recurrence of disease before or shortly after the diagnosis of brain metastases, which can represent new seeding as well as grow th of already exisring microscopic brain metastases. So rather than PCI treatment failure, brain metastasis may indicate the non-effectiveness of chemotherapy and locoreginal therapy: The same goes for the differences in brain metasratic free and overall survival, which are equally relaced to the recurrence of systemic disease.

The administration of PCI in combination with systemic chemorherapy is potentially ncurutoxic; a wide: range of neurologic abnormalities have luen reported tugether with the occurrence of whice matter changes and brain atrophy (displaved by ventricular dilatation as well as widening of sulci), particularly in longterm survivors $[4-10,16]$. Pedersen et al [4] concluded from the combined data of 8 relatively small retrospective studies with a total of 123 long-term survivors of whom 102 parients received PCI that $45 \%$ had severe clinical CNS defecrs. The significance and frequency of the possible treatment related CNS abnormalities varied strongly in different studies. Most of the existing studies have atcributed unexplained neurologic condicions following treatment co neurotoxicity of the chemotherapy and PCI combination, without clearly defining them. Johnson et al [9] studied 20 long-term survivors and found an increased CNS toxicity when PCI was administered in larger fraction doses or concurrent with chemotherapy. In the present study, PCI was delivered after termination of the systemic chemotherapy. Possible trearment-related neurologic complications and scan abnormaliries were diagnosed more frequently in long-term survivors treared with $\mathrm{PCl}$ than long-term survivors not treated with PCI; $7 / 9$ versus $1 / 9$ neurologic complications and $5 / 9$ versus $3 / 9$ radiologic abnormalities respectively. In contrast with studies where chemotherapy has followed by or been concurrent with PCI $[7-9,16]$ and consistent with a study in which PCI was applied after chemotherapy [10], the neurologic complications were relatively mild for the majority of the patients.

Brain irradiarion in combinarion wirh or without chemotherapy is hazardous for the CNS and white matter in particular 
[19]. White matter changes are more sensitively imaged by MRI as focal hyperintensities of the central white matter [20, 21] than by CT. Some researchers have concluded that these white matter abnormalities are normal age related changes [22-25], while orhers suggested a marked relation with hypertension [26-29]. In a prospective study which was conducted to explore the value of routine cranial MR scanning as a pretreatment screening procedure in patients with SCLC, white matrer hyperintensiries were found in 14 (36\%) of 39 patients who varied in age from 51 to 78 years [30]. As patients were primarily evaluated with CT-scan, the white marter abnormalities seen on MR scans of long-term survivors in this study cannot be attributed a priori to radiation damage. The higher frequency of possible treatment related radiologic abnormalities in long-term survivors treated with PCI is partially explained by the longer follow-up time, because radiation induced CNS changes tend to be irreversible and progressive over time [19]. Therefore, the possible treatment related radiologic abnormalities do not necessarily confirm the association of $\mathrm{PCI}$, in the present siudy.

We conclude that the observed survival bencfie in parients reated with PCI could be the result of PCI, but as the study was not randomized other treatment related factors may play a role as well. Randomized studies with more effecrive systemic treatment protocols would allow more definite conclusions. Possible treat- ment related adverse effects, though relatively mild, were seen more frequently in long-term survivors treated with PCI. The higher frequency of adverse effects might be explained by a longer follow up and differences in imaging technique. However, every adverse effect of PCI is valid as long as the efficacy of $\mathrm{PCI}$ is nor clearly established. The results of this study confirm the general belief that PCI may be effective by increasing the brain metastatic free survival, and its use with systemic chemotherapy bears the risk of CNS toxicity.

\section{References}

1. Hirsch FR. Hansen HH, Paulson OB. Cenral nerwous system metastases in small cell carcinoma of the lung: A review. In: Ongerboer de Visser BW, Boseh DII. Woerkom-Eykenboom WMH, eds. Neuro-Oncology, Clinical and Experimental Aspects: Developments in Oncology, 3 Hague: Martinus Nighoff, 1980: 140-166.

2. Nugent JL, Bunn PA Jr, Matthews MJ, et al. CNS metastases in small cell bronchogenic carcinoma: Increasing frequency and changing pattern with lengthening survival. Cancer 44: 1885-1893, 1979.

3. Hansen HH, Kistiansen PEG. Chemotherapy of small cell lung cancer. Eur J Cancer 27: 342-349, 1991.

4. Pedersen AG, Kristjansen PEG, Hansen HH. Prophylacric cranial irradiarion and small cell lung cancer. Cancer Treat Review 15: 85-103, 1988.

5. Catane R. Schwade JC; Yarr I. et all. Follow-up neurological evaluation in patients with small cell lung carcinoma treated wich prophylacric cranial irrsdiation and chernotheraps. Ine I Radiat Oncol Biol Phis 7: 105-109. 1981. 
6. Craig JB, Jackson DV, Moody D. Cruz JM, Pope EK. Powell BL, Spur CL, Capizzi RL. Prospective evaluation of changes in computed cranial tomography in parients with small cell lung carcinoma treated with chemorherapy and prophylactic cranial irradiation. J Clin Oncol 2: 1151-1156, 1984.

7. Frytak S, Shaw JN, et al. Leucoencephaloparhy in small cell lung cancer patients receiving prophylactic cranial irradiation. Am J Clinic Oncol 12: 27-33, 1989.

8. Lee JS, Umsawasdi Th, et al. Neuroroxicity in long-term survivors of small cell lung cancer. Int J Radiat Oncol Biol Phys 12: 313 - 321, 1986

9. Johnson BE, Becker B, Goff WB II, Perronas N, Krełbiel MA. Makuch RW. MeKenna G. Glatstein E. Ihde DC. Neurologic, neuropsychologic, and computed cranial scan abnormalities in 2- to 10 -year survivors of small celi lung cancer. J Clin Oncol 3: 1659 . $1667,1985$.

10. Laukkanen E, Klonoff H, Allan B, Graeb D, Murray $N$. The role of prophylactic brain irradiation in limited stage small cell lung cancer: Clinical, neuropsychologic, and CT-sequelae. Int I Radiat Oncol Biol Phys 14: 1109-1117. 1988.

11. Hirsch FR, Paulson OB, Hansen HH.

Intracranial metastases in small cell carcinoma of the lung: Prognostic aspects. Cancer 51: 529-533, 1983.

\section{Turrisi A. Glover 1)J, Masun B. A preliminary} report: Concurrent twice daily radiotherapy plus platinum-etoposide chemotherapy for limired small cell lung cancer. In J Radiar Oncol Biol Phys 15: 183187. 1988.

13. Maksymiuk AW, Jeu JR, Earle JD, Su JQ, Dieger FA. Mailiard JA, Kardinal GA. Krook JE. Veeder MH. Wiesenfeld M. Tschetrer LK. Levit R. Sequencing and schedule effects of cisplatin plus etoposide in small-cell lung cancer: Resulis of a North Central Cancer Treatment Group randomized clinical trial. J Clin Oncol 12: 70-76, 1994.

14. Coy P, Hodson I, Murray N, Pater JL, Payne
DG, Amold A, Kostashuk E, Dixon P, Evans WK. Wierzbicki R, Feld R, Maroun J, Wilson K. Pattems of failure following loco-regional radiotherapy in the treatment of limited stage small cell lung cancer. Int J Radiar Oncol Biol Phys 28: 355-362, 1993.

15. Rosen ST, Makuch RW. et al. Role of prophylactic cranial irradiation in prevention of central nervous system metastases in small cell lung cancer. Potential benefit restricted to patients with complete response. Am J Med 74: 615-624, 1983

16. Fleck JF, Einhorn LH, et al. Is prophylactic cranail irradiation indicated in small-cell lung cancer? J C.lin Oncoi 8: 209-214, 1990

17. Rosenstein M, Armstrong J, Kris M, et al A reappraisal of the role of prophylactic cranial irradiation in limired smalf cell lung cancer. Int J Radiat Oncol Biol Phys 24: 43-48, 1992.

18. Hirsch FR, Paulson OB, Hansen HH, VraaJensen J. Intracranial metastases is small cell carcinoma of the lung: Correlation of clinical and autopsy findings. Cancer 50: 2433-2437, 1982.

19. Sheline GE, Wara WM, Smith V. Therapeutic irradiation and brain injury. In / Radiat Oncol Biol Phys 6: 1215-1228, 1980.

20. Constine LS, Konski A, Ekholm S, McDonald S, Rubin P. Adverse effects of brain irradiation correlated with MR and CT imaging. int J Radiar Oncol Biol Phys 15: 319-330, 1988.

21. Frytak, S, Earnest IV F, O'Neill BP, Lee RE, Creagan ET, Trautmann JC. Magnetic resonance imaging for neurotoxicity in long-term survivors of carcinoma. Mayo Clin Proc 60: 803-812, 1985.

22. Hendrie HC. Farlow MR. Austrom MG, Edwards MIK. Williams MA. Foci of increased T2 signal intensity on brain MR scans of healthy elderly subjects. AJNR 10: 703-707, 1989 .

23. Kobari M. Meyer IS. Ichijo M, Ovạrez WT. Leukoaraiosis: correlation of MIR and CT findings 
24. Zimmerman RD, Fleming CA, Lee CPB, et al. Periventricular hyperintensity as seen by magnetic resonance: prevalence and significance. AJNR 7: 1320, 1986.

25. Wahlund LO, Agartz I, Almquist O, et al. The brain in healthy individuals: MR imaging. Radiology 174: 675-679, 1990.

26. Awad IA, Spetzler RF, Hodak JA, et al.

Incidental lesions noted on magnetic resonance imaging of the brain: prevalence and clinical significance in various age groups. Neurosurgery 20: 222-227, 1987.

27. Fazekas F, Chawluk JB, Alavi A, et al. MR signal abnormalities at $1.5 \mathrm{~T}$ in Alzheimer's dementia and normal aging. AJR 149: 351-356, 1987.

28. George AE, de Leon MJ, Kalnin A, et al. Leukoencephalopathy in normal and pathologic aging 2: MRI of brain lucencies, AJNR 7: 567-570, 1986.

29. Soges LJ, Cacayorin ED, Petro GR, et al. Migraine: evaluation by MR. AJNR 9: 425-429, 1988.

30. Van de Pol M, van Oosterhour AGM, Twijnstra A, Wilmink JT, ten Velde G. Diagnostic value of MR imaging in the detection of brain metastases at initial staging in small cell lung cancer. Neuroradiology (in press). 


\section{Follow-up of cognitive func- \\ tioning in patients with}

small cell lung cancer 


\section{Introduction}

The current treatment regimen of patients with small cell lung cancer (SCLC), including systemic chemorherapy with or without chest irradiation and prophylactic cranial irradiation (PCI), is potentially neurotoxic. Prophylactic cranial irradiation in particular has been blamed for adverse effects on the central nervous system (CNS) and its administration has become controversial $(19,3,10,11,13,12,6,7,21)$.

The white matter of the CNS is especiallyvulnerable to radiation $(1,2,18,14,4)$

Chemorherapy can by itself induce white matter injury, as well as enhance the toxic effects of radiation. Computed tomography and magnetic resonance studies have shown evidence of both white matter and cortical atrophy $(18,14,4)$. Clinically, the neuroanatomic changes seen by computed tomography or magnetic resonance are associated with impairment of mental function, seizure disorders, and motor abnormalities. The most prominent clinical fearures, however, involve impairment of cognirive functioning $(2,14)$.

In the present study, the results of a neurologic and neuropsychologic follow-up of a group of consecutive parients with SCLC are reported. The purpose of the current investigation was to establish early signs of cognirive dysfunction by a neuropsychologic follow-up. The neuropsychologic test battery was designed to allow group comparisons of neuropsycho- logic functioning on different domainsrather chan the diagnosis of specific deficirs in individual patients. The present study also compared patients in their pretherapeutic condition with matched controls in an attempt to distinguish between the impact of disease and treatment related factors.

\section{Methods and materials}

Thirty two consecutive SCLC patients were enrolled in a prospective study. All patients were initially treated with chemotherapy, consisting of cyclophosphamide $1000 \mathrm{mg} / \mathrm{m} 2$, doxorubicin $45 \mathrm{mg} / \mathrm{m} 2$, and etoposide $100 \mathrm{mg} / \mathrm{m} 2$ on days 1,3 , and 5 for five cycles. After chemorherapy, patients in complete remission received PCI, in a total dose of $30 \mathrm{~Gy}$ on the entire cranial content, in 15 fractions of $2 \mathrm{~Gy}$ over 2 to 3 weeks. Patients were seen by a neurologist upon diagnosis and at quarterly intervals thereafter (biannually after a year). A computed tomography scan of the brain was performed before treatment. More frequent neurologic consultations and other ancillary tests were done as required. Patients with brain metastases were excluded from the analysis.

\section{Complete neuropsychologic evaluation} included history, observation, and established procedures for testing inrelligence, mental control, information processing speed, visuo-motor speed, verbal and visual memory, fine moror functions, and eyehind coordination. Inrelligence was tested pretherapeurically with the Groninger 
Intelligentie Test (17), a Dutch-language standardized intelligence battery. Mean results on the Dutch version of the 15 Word auditory verbal learning test (15) the Stroop color-word test (15), and the Trailmaking test parts A and B (15) were analyzed, as for these tests, control data were available (9). Parients in pretherapeutic condition (session 1) were compared to controls, who were matched for age, gender, and educational level (16). Tests were repeated during chemotherapy (session 2), after chemotherapy (session 3), 1 monch after PCI (session 4), and 5 months after PCI (session 5).

For the Trailmaking test, subjects are asked to connec successive numbers (part A), or alternating successive numburs and letters (part B) on a card (15). In the Stroop test subjects have to read color names (word), name colors (color), and read color names printed in a different color (color-word); during the color-word part of the test, subjects have to inhibit auromacic reading responses, which causes a delay (interference effect) compared to the color part of the test (15) In the 15 word test, subjects are presented the same series of 15 words five times and arc asked to reproduce these words after each presentation, as well as after 20 minutes. After the last spontaneous recall they are asked to recognize the 15 target items from a list of 30 words (15). Total recall capaciry over five trials (total), difference between the worst and the best score over five trials (delta), the delayed recall, and the recognitionare analyzed. The relevant measure in the Trailmaking and Stroop tests is the performance speed.

Patient characteristics are listed in Table 1. None had a history of severe head injury or chronic intoxications (alcohol or psychoactive drugs). Brain metastases were diagnosed in 3 parients ar the onser of SCLC and in 11 orher parients during the course of the disease. Four other patients were excluded from further analysis, as they had not been neuropsichologically tested betore the start of chemothcrapy. Three parients with rapidly progressive SCLC died within the first 6 months. Thereforc, the number of patients was reduced from 14 in the first two test sessions to 11 in the third test session. Only 5 patients were treated with PCI. The sample t-test was used for staristical analysis of the mean test results.

\section{Results}

Regular neurologic examination revealed no CNS abnormalities in paricnes withour evidence of CNS metastases. All patients without evidence of rapidly progressive disease or CNS merastases remained ambulatory and capable of self care. Some patients complained about concentration problems, difficulties in recalling telephone numbers, slight word finding problems, and loss of libido. These complaints were heard at diagnosis, as well as during the course of the disease, when specifically asked. 


\begin{tabular}{lcccc} 
& Total & Session 1 and 2 & Session3 & Session 4 and 5 \\
\hline $\mathrm{n}$ & 32 & 14 & 11 & 5 \\
male & 26 & 12 & 9 & 4 \\
$\begin{array}{l}\text { limited } \\
\text { disease }\end{array}$ & 12 & 4 & 1 & 3 \\
$\begin{array}{l}\text { age mean } \\
\text { (range) }\end{array}$ & $64(45-78)$ & $63(51-73)$ & $64(54-73)$ & $58(52-62)$ \\
$\begin{array}{l}\text { IQ mean } \\
\text { (range) }\end{array}$ & $103(71-129)$ & $103(87-116)$ & $103(87-116)$ & $101(95-110)$ \\
\hline
\end{tabular}

Table 1. Patients charateristics: total $=$ all patients enrolled; session 1 and $2=$ precherapeutic and during chemotherapie; session $3=$ after chemotherapy; session 4 and $5=$ one and five months after prophylactic cranial irridarion; $\mathrm{IQ}=$ intelligence quotient.

The analysed neuropsychologic tests in the study measure aspecific effects of brain dysfunction, where perceptualmotor speed, attention span, flexibility, and memory are concerned. The mean results on the Dutch version of the 15Word auditory verbal learning test (15) the Stroop color-word test (15) and parts $A$ and $B$ of the Trailmaking test (15) are shown in Table 2. The mean results scored on these tests by the patients in pretherapeutic condition were significantly worse than those of matched controls ( $p<$ $0.001)$. The rest results did not show any significant deterioration during or after chemotherapy, nor after PCI $(0.1<p<$ $0.8)$. In the 5 parients taking part in all the test sessions, the changes of the various test items throughout time did not show a consistent pattern, yet were more indicative of improvement than of deterioration. 


\begin{tabular}{|c|c|c|c|c|c|c|}
\hline & & session 1 & session 2 & $\operatorname{session} 3$ & session 4 & session 5 \\
\hline & & $(n=14)$ & $(n=14)$ & $(n=14)$ & $(n=11)$ & $(n=5)$ \\
\hline \multicolumn{7}{|c|}{ T'railmaking Test } \\
\hline pare $A$ & $41.3(16.1)$ & $50.5(23.3)$ & $45.2(16.6)$ & $41.3(1+.6)$ & $32.2(10.0)$ & $29.3(5.3)$ \\
\hline pare B & $62.6(24.1)$ & $77.0(26.4)$ & $75.4(30.4)$ & $72.5(24.1)$ & $78.8(35.7)$ & $88.7(57.5)$ \\
\hline \multicolumn{7}{|l|}{ Stroop Test } \\
\hline word & $40.6(5.1)$ & $50.4(6.3)$ & $47.9(8.4)$ & $49.8(8.7)$ & $47.4(7.2)$ & $48.5(8.4)$ \\
\hline color & $5.5 .4(4.1)$ & $63.0(9.5)$ & $57.1(9.2)$ & $6.3 .3(13.4)$ & $64.4(12.3)$ & $59.3(7.0)$ \\
\hline color-word & $93.7(17.7)$ & $1.34 .1(36.2)$ & $110.9(27.0)$ & $127.7(40.1)$ & $1.38 .4(50.9)$ & $120.0(33.4)$ \\
\hline interference & $38.3(12.0)$ & $71.1(32.2)$ & $53.8(23,3)$ & $64.4(30.9)$ & $74(39.2)$ & $61.0(31.0)$ \\
\hline \multicolumn{7}{|l|}{15 Word Test } \\
\hline total & $49.0(5.5)$ & $32.5(9.3)$ & $35.6(11.6)$ & $38.2(8.6)$ & $38.4(12.4)$ & $41(1.5 .6)$ \\
\hline delte & $6.9(1.3)$ & $4.9(1.6)$ & $5.0(2.2)$ & $5.0(2.1)$ & $4.2(1.5)$ & $4.5(3.0)$ \\
\hline delased recall & $10.3(2.1)$ & $6.4(2.6)$ & $6.6(2.6)$ & $7.6(2.5)$ & $7.2(3.6)$ & $7.0(3.7)$ \\
\hline recognicion & $29.4(0.8)$ & $27.0(2.1)$ & $26.1(2.8)$ & $26.4(3.5)$ & $28.6(2.6)$ & $27.5(3.1)$ \\
\hline
\end{tabular}

Tahle 2. Nean Resules (standard deviarions) of Neuropsychologic Tests of Marehed Conrrols and Palients, During Successive Test Sessions.

Statistical analysis (sample (-test) revealed significant differences between patients in session 1 versus matched controls (p $=<0.001)$. bur no significant inter-session differences $(0.1<p<0.8)$; session $1=$ prerherapeutic; session $2=$ during chemotherapy; session $3=$ after chemorherapy; session $4=1$ month after prophylactic cranial irradiation: $\operatorname{session} 5=5$ monsh aftes prophylactic cranial irradiacion. 


\section{Discussion}

Follow-up assessments of cognitive funccion in patients with SCLC from diagnosis, or a comparison between their pretherapeutic performance and that of matched controls, have not been performed as yet. The neurotoxicity of the combination of chemotherapy and PCI, in the context of SCLC, is described mainly as late sequelae in long-term survivors. Theorerically speaking, nonmetastatic neurologic complications of SCLC or sequelae of its treatment can arise at any moment, starting from diagnosis.

Chemorherapy related cerebral injury presents itself early, within weeks to months of treatment $(14,20)$. With the combination of cyclophosphamide, doxorubicin, and etoposide as used in our study, however, no CNS injury has been reported so far. Laukkanen et al. (12) identified headache and mild nausea during PCI, and concentration difficulties and a nonspecific lack of energy from 1 monch after PCI as transient and early sequelae. Licciardeilo er al. (16) described 2 patients with progressive confusion 6 and 10 weeks after PCI. Irreversible adverse effects do occur usually 3 months after PCI $(14,20)$.

\section{Pretherapeutic neuropsychologic test} results of the group of patients as a whole were generally worse than those of the matched controls. Possible explanations could be that the parienes were in suboprimal physical condirion and were preoccupied with their future. The attending effective changes may have influenced their test performance. Although all patients remained motivated and none showed clinical evidence of significant depression, their general physical and mental condition cannot be ruled out. Microscopic brain metastases and paraneoplastic mechanisms may have further compromised the results (5). Moreover, we are unaware of the effects of chronic cigarette smoking, prior medication or brain traumas, and the interactions of these interindividually different data with the current treatment. Hill found that smoking may have a negative effect on performance speed in elderly adults (8).

An earlier study (21), performed by us, revealed no focal deficits such as aphasia, apraxia, or agnosia. None of the patients showed clinical signs of these specific disorders in the present study, although they were not specifically tested for. The present study also revealed no additional therapy effects on measures of aspecific effects of diffuse brain dysfunction; during and after treatment, some neuropsychologic test results even improved slightly. Standard neurologic examination revealed no serious neurotoxicity; specific history for cognitive dysfunction did not reveal more than a slight indication of brain dysfunction in some parients, objecrive CNS abnormalities were detected only in patients with brain metastases. This finding contrasts with several studies which have reported a considerable number of severe neurologic complications of therapy, especially in long-term 
survivors $(19,3,10,11,13,12,6,7,16)$. The fraction dose of PCI in these studies $(3,10,11,13,12,6,7,16)$ was at least $3 \mathrm{~Gy}$; this may have been more harmful than the $2 \mathrm{~Gy}$ used in our study.

The difference between the group of patients in pretreatment condition and the group of matched controls can not be interpreted a priori as clinically significant; although it could be meaningful for the individual patient in view of the standard deviacions. The same goes for the therapy effects; although the mean group results remained relatively stable, the considerable standard deviations in combination with the small sample size makes it likely that the cognitive performance of individual patients were impaired. The number of patients is too small for definite conclusions; half of the study population developed brain metastases or died before neurotoxicity assessment could be performed, and we can not exclude longterm effects. However, the differences berween patients in pretherapeutic condition and matched controls may very well have concributed to the short and longterm neurotoxicity reported in orher srudies $(19,3,10,11,13,12,6,7,21,16)$. Our results confirm the importance of a pretherapeuric assissment in this field of research.

\section{Conclusions}

In parients with SCLC who were treated with chemotherapy and PCI, follow-up of cognitive functioning revealed no adverse treatment effects within 5 months after termination of PCI. However, when pretherapeutically compared to matched controls, parients performed significantly worse, suggesting that a nontreatment related cognitive impairment could exist in patients with SCLC.

\section{References}

\section{Burger, P.C.; Mahaley, M.S.; Dudka, L.; Vogel,} F.S. The morphologic effects of radiarion administered therapcurically for intracranial gliomas: a postmortem study of 25 cases. Cancer 44: 1256-1272; 1979.

\section{Constine, L.S.; Konski, A.; Ekholm, S.;} MeDonald, S.; Rubin, P. Adverse effects of brain irradiation correlared with MR and CT imaging. Int. J. Radiat. Oncol, Biol. Phys 15: 319-330; 1988.

\section{Craig. J. B.: Jackson. D.V.; Moody, D.; Cruz,} J.M.:Pope, E.K.; Powell, B.L.; Spurr, C.L.; Capizzi, R.L. Prospective evaluation of changes in computed cranial tomography in patients with small cell lung carcinoma reared with chemotherapy and prophylacric cranial Irradiarion. J. Clin. Oncol. 2: 1151-1156; 1984.

4. Curnes, I.T,; Laster, D.W.: Ball, M.R.; Moody, D.M.: Witofski, R.I. MRI of radiation injury of the brain. AJNR 147: 119-124: 1986.

\section{Elrington, G.M.; Mutray, N.M.: Spiro, S.G.;} Newsom-Davis, J. Neurological parancoplastic syndromes in patients with small cell lung cancer. A prospective survey of 150 parients. J. Neurol. Neurosurg. Psychiarry 54: 764-767; 1991.

6. Prytak, S.: Shaw, J.N.; Lee, R.E.; Eagan, R.T.; Shaw, E.G.; Richardson, R.L.: Creagan, E.T.; Coles , D.T.; Jer, J.R. Treatment toxicities in long-term survivors of limited small cell lung cancer. Cancer Invest. 6: 669-676; 1988.

7. Frytak, S.; Shaw, J.N.; O'Neill, B.P.; Lee, R.E. 
Eagan, R.T.; Shaw, E.G.; Richardson, R.L.; Coles , D.T.; Jett, J.R. Leukoencephalopathy in small cell lung cancer patients receiving prophylactic cranial irradiation. Am. J. Clin. Oncol. 12: 27-33; 1989.

8. Hill, R.; Residual effects of cigarette smoking on cognitive performance in normal aging. Psychol. Aging 4: 251-254; 1989.

9. Houx, P.J.: Vreeling, F.W.; Jolles, J. Age-associated cognitive decline is related to biological life events. In: Iq̣bal, K., McLaglin, D.R., Winblad, B., Wisniewski, H.N., eds. Alzheimer disease: basic mechanisms, diagnosis and therapeutic strategies. Chichester, UK: Wiley; 1991: 353-358.

10. Johnson, B.E.; Becker, B.; Goff, W.B.; Patronas, N.; Krehbicl, M.A.; Makuch R.W.; McKenna, G.; Glatstein, E.; Ihde D.C. Neurologic, neuropsychologic, and compured cranial tomography scan abnormalities in 2- to 10-year survivors of small-cell lung cancer. J. Clin. Oncol. 3: 1659-1667; 1985.

11. Johnson, B.E.; Patronas, N.; Hayes, W.; Grayson, J.; Becker, B.; Gnepp, D.; Rowland, J.; Anderson, A.; Glatstein, E.; Ihde, D.C.; Frank, J.A. Neurologic. computed cranial tomographic, and magnetic resonance imaging abnormalities in parients with smallcell lung cancer: further follow-up of 6- to 13-year survivors. J. Clin. Oncol. 8: 48-56; 1990.

12. Laukannen, E.; Klonoff, H.: Allan, B.; Graeb, D.; Murray, N. The role of prophylactic brain irradiation in limited stage small cell lung cancer: clinical, neuropsychologic, and CT sequelae. Int. J. Radiar. Oncol. Biol. Phys. 14: 1109-1117; 1988.

\section{Lee, J.S.; Umsawasdi. T.; Lee. M.: Barkley,} H.T.: Murphy, W.K: Welch, S.: Valdivieso, M. Neurotoxicity in long-term survivors of small cell lung cancer. Int. J. Radiar, Oncol. Biol. Phys. 12: 313-321; 1986.

14. Lee, Y.Y; Nauert, C; Glass, J.P. Treatment-relared white matrer changes in cancer parients. Cancer 57: 1473-1482: 1976.

15. L czak, M.D. Neuropsychological Assessment. 2nd ed. New York, Oxford University Press; 1983.

16. Licciardello, J.T.W.; Cersosimo, R.J.; Karp, D.D.; Hoffer, S.M.; Paquetce-Tello, D.A.; Ki Hong, W.

Disturbing central nervous system complications fol. lowing combination chemotherapy and prophylactic whole-brain irradiation in patients with small cell lung cancer. Cancer. Treat. Rep. 69: 1429-1430; 1985.

17. Lureijn, F.; Ploeg,van der F.A. Groninger Intelligentic Tesc. Lisse: Swers \& Zeitlinger, 1983.

18. Packer, R.].; Zimmerman, R.A.; Bilaniuk, L.T. Magneric resonance imaging in the evaluation of tre. atment related central nenous system damage. Cancer 58: 635-640; 1986.

19. Pedersen, A.G.; Kristjansen, P.E.; Hansen, H.H. Prophylactic cranial irradiation and small lung cancer. Cancer Treat. Rev. 15: 85-103; 1988.

20. Sheline, G.E.; Wara W.M.: Smith V. Therapeutic Irradiation and brain injury. Int. J. Radiac. Oncol. Biol. Phys, 6: 1215-1228; 1980.

21. Twijnstra, A.: Boon, P.J.: Lormans, A.C.; Velde. ten G.P. Neurotoxicity of prophylactic cranial irradiation in patients with small cell carcinoma of the lung, Eur. J. Cancer Clin. Oncol. 23: 983-986; 1987. 


\section{Central nervous system toxi-}

city in long-term survivors of small cell lung cancer 


\section{Introduction}

\section{Central nervous system (CNS) metasta-} ses are an important cause of morbidity and mortality in patients with small cell lung cancer (SCLC) [1]. With lengthening survival the risk of CNS metastases increases to a cumulative risk of $58-80 \%$ in two-year survivors not treated with prophylactic cranial irradiation (PCI) [2]. For patients who did not achieve complete remission (CR), the actuarial likelihood of developing CNS merastases was nearly $100 \%$ at 2 years, irrespective of the administration of PCI [3]. PCI significantly reduced the frequency of brain metastases in a number of prospective, randomised clinical trials [4]. Though there was no evidence of improved survival, PCI became an optional part of the treatment program for patients with a CR to systemic chemotherapy, with or without chest radiation therapy $[4]$.

It soon became evident, however, that the application of $\mathrm{PCI}$ involved the risk of serious CNS injury [5-9]. Both chemotherapy and cranial irradiation are potentially hazardous for the CNS and the white matter in particular [10]. Small cell lung cancer patients treated with chemotherapy alone showed less adverse effects than those who were treated with chemotherapy and PCI [4]. Administration of PCI in larger fraction doses, concurrent with or sandwiched by chemotherapy seemed to be associared with a higher frequency of CNS abnormalities [9]. However, exact frequency, severity, and etiology of these
CNS abnormalities in long-term survivors of SCLC are unknown, at present.

Studies on neurotoxicity in SCLC lack sufficient patient numbers and uniformity to allow definite conclusions on this topic [4, 11-14].

Using neurologic and neuropsychologic assessment, and computed tomography (CT) scanning or magnetic resonance (MR) imaging of the brain, the present study describes the neurologic outcome of 59 long-term survivors, defined as parients surviving the diagnosis of SCLC for more than two years. The purpose of the current investigarion was to isolate residual effects of the treatment of SCLC. It was hyporhesised that the trearment would affect mainly the cognitive performance of the patients. An atrempt was made to asses the impact of different treatment-protocols on learning and memory, memory span, speed of information processing, and attention shifting. Specifically, the most sensitive neuropsychologic tasks ro detect deficits in these cognitive domains were used to compare patients not treated with PCI, patients treated with PCI after chemotherapy, patients treated with $\mathrm{PCl}$ concurrent with or sandwiched by chemotherapy, and matched controls. 


\section{Patient population}

Pulmonologists in the Netherlands were asked to request patients surviving the onser of SCLC more than two years to take part in the present study on a voluntary basis. They were visited by the aurhors for neurologic (AvO) and neuropsychologic assessment (BdG or $\mathrm{RvV}$ ). Within two months after these assessments a CT or MR scan of the brain was performed in the different hospitals.

Between January 1991 and January 1993, 59 patients were enrolled. Six patients were excluded from further analysis; four patients with a cerebrovascular accident, one patient with a Korsakoff syndrome due to alcohol abuse, and one parient with a severe head injury prior to diagnosis of SCLC. For analysis of the neuropsychologic test results and for the determination of treatment effects four more patients were excluded, two because of insufficient command of the Dutch language, and two patients because they were not treated with chemotherapy or PCI.

\section{Treatment}

Fifty-one patients, were treated with chemorher:lpy, with or without chest irradiation. Thirty patients were treated with PCI, 23 patients did not receive PCI. Two parients were not treated with chemotherapy or PCI. These latter two patients underwent a lobectomy, in one followed by chest irradiation.
Patients were divided in three groups, according to the received treatment: group 1 chemotherapy alone $(n=21$, including two patients with insufficient command of Dutch), group $2 \mathrm{PCI}$ after termination of chemotherapy $(n=19)$, and group $3 \mathrm{PCI}$ concurrent or sandwiched with chemotherapy $(\mathrm{n}=11)$. Patient characteristics and treatment specifications are listed in table 1.

The group of controls comprised healthy subjects $(n=29)$, enrolled in a study on memory disturbances in the elderly [15]. They were matched on an individualised basis to the parients for age and educational level. 


\section{Characteristies}

age

$64.5(7.2)$

$59.7(9.1)$

$64.7(9.9)$

survival

$5.4(2.8)$

$4.1(2.5)$

education level

$3.0(1.4)$

$3 .+(1.6)$

\section{Chemotherapy}

CTX,DOX,VCR

CTX,DOX,ETO

\section{CTX,DOX,ETO/CTX,VCR,MTX}

CTX,VCR.MTX

\section{CTX.CIS,ETO}

CTX,CIS,ETO/GCNU,ETO,MTX

CTX.CIS,ETO/CCNU,HMM

carboplatin and ifosfamide

carboplarin and VC:R

\section{I.ocoregional Radiotherapy}

Prophylactic Cranial Irradiation
$15 \times 2.0 \mathrm{~Gy}$

$12 \times 2.56 y$

$10 \times 3.0 \mathrm{~Gy}$
7

9

0

0

1

2

0

0

0

11

0

0

0
1

16

0

0

0

0

0

1

0

1

9

Table 1. Patient characteristics and treatment specifications.

Group $1=$ chemotherapy alone; group $2=$ sequential prophylactic cranial irradiation: group $3=$ concurrent or sandwiched prophylacric cranial irradiacion. Age, survival ( $^{\mathrm{p}} \mathrm{p}=0.00 \%$. One Factor Anova), and education level of patients are displayed as mean and (standard deviation). Matched controls $(n=29)$ had a mean age $61.4(7.2)$ year and education level of 3.5 (1.2). Different treatment modalities are specified; $\mathrm{CTX}=$ cyclofosfamide; $\mathrm{DOX}=$ doxorubicin: $\mathrm{ETO}=\mathrm{e}$ oposide; $\mathrm{VCK}=$ vincristine: $\mathrm{CIS}=$ cisplatin; $\mathrm{MTX}=$ methotrexate; $\mathrm{HMM}=$ hexamethyimelanine. 


\section{Neurologic assessment}

The neurologic evaluation included history, assessment of functional status, and neurologic examination. We specifically concentrated on complaints or abnormal physical findings related to the CNS. Pacients were screened for intoxications, head injuries, and cardiovascular risk facrors as hypertension, diabetes mellitus, and coronary artery disease. The use of antihypertensive or ancidiabetic medicarions was used to define hypertension or diabetes mellitus, respectively. The diagnosis of coronary artery disease required a documented history of myocardial infarcrion or an abnormal electrocardiogram for the presence of ischemic changes or arrhytmias. Functional status assessment included a clinical rating scale for the ability to perform self care and basic social maintenance using the Barthel score [16], the Karnofsky scale [17], and the score of Order, Hellman and von Essen [18].

Grading of ventricular enlargement, cortical atrophy, cerebellar atrophy, white matter lesions by CT and MR scan

All CT and MR scans were revicwed by a neuroradiolngist (JW) who was unaware of the treatment and clinical condition of the patient. CT and MR scans were evaluated for ventricular enlargement, cortical atrophy, comparison of cerebral and cerebellar atrophy, and the extent of white matter lesions. Ventricular enlargement was rated according to the Evans index [19]. Cortical atrophy was judged as none if no sulcus was wider than 5 millimetres, light if a few sulci were wider than this value, moderate if more sulci but less than the half of them were wider than 5 millimetres, and severe if more than half of the sulci were wider than 5 millimerres. Visual assessment was used for the comparison of cerebral and cerebellar atrophy as less, the same, or greater. The extent of white matter lesions was judged as none if no such lesions were present, light if white matter lesions were restricted to a periventricular zone of no more than one ventricle width, moderate if white matter lesions were scattered throughout the white matter excepting the capsula interna, and severe if the total white marter was affected.

\section{Neuropsychologic assessment}

For the neuropsychologic testing battery five tests (rwo memory rests and three tests in which speed of performance was the main parameter) were chosen because of their sensirivity in distinguishing between chronic solvent exposed workers, intermittently exposed workers and healthy controls [20]: the Auditory Verbal Learning Test (AVLT) [21], the Digit Span [21], a paper and pencil Memory Scanning Test (MST) [22], Concept Shifring Test (CST) [15], and the Stroop Color-Word Test [21].

1) In the AVLT 15 one-syllable nouns. recorded with a cassette tape, were presented five times in the same order. The subjects were instructed to recall all nouns they could remember immediately 
after the presentation (immediate recall).

The measure parameters used in this test are the number of words recalled on the first trial, the sum of the differences between the scores of the successive trials (delta), the delayed recall and the delayed recognition. The later two were measured 30 minutes after trial 5 .

2) In the Digit Span Forwards the largest number of digits of a sequence that was repeared in the right order by the subject was counted.

\section{3) A paper and pencil MST tested the} slowing caused by memory load, in a fashion similar to the Sternberg paradigm [23]. The test consisted of four different subtests, each on a separate sheer of A4 paper, containing a $12 \times 12$ matrix of letters. In each matrix, 24 letrers were target letrers and the other letters were distracters. For each subtest, the subject was requested to memorize 1-4 letters, the memory set, and to cross them out as quickly as possible, withour making mistakes, each time they occurred on the rest sheet. In subtest 1, the memory set consisted of 1 letrer (all 24 target letters were the same). In subrest 2,3, and 4, the memory ser consisted of 2,3 , and 4 different target letters, respectively. The intercept and the slope of the time scores, calculated by means of linear regression, are the parameters used with this test.

\section{4) In Stroop Color-Word Test the sub-} ject's performance was measured as time scores of the three subtests A, B, and C, and the interference induced by the
'Stroop' effect [21].

5) The CST consists of three subtests, analogous to the Revised Trail Making Test. Each subtest consists of 16 small circles (diameter $15 \mathrm{~mm}$ ), grouped in a larger circle (diameter $16 \mathrm{~mm}$ ), printed on a A4 paper. In the small circles the test items are randomly princed in the small circles: digits 1-16 in subtest $A$, letters $A$ $P$ in subrest $B$ and both digits 1-8 plus letters A-H in subtest $\mathrm{C}$. The subjects are requested to cross out the items in the right order. The scores are time scores for each of the three subtest and the effect of interference induced by the digits/letters category swirch.

The different test parameters were combined in four cognitive domains: learning and memory, memory span, speed of information processing, and attention shifting. Borh the interference effect of the Stroop Test and the CST are viewed as a measure of aspects of arousal and alereness on execurive functions [22], and were combined in a relative score, accoiding the formula: $(C-A+B) / 2) /(A+B) / 2) * 100$, in which $A$, $B$, and $C$ represent the order of the three sub tasks of the Stroop and the CST.

\section{Statistical analysis}

Univariate F-tests and Kruskal-Wallis test were used to assess significance in the distribution of characteristics, performance scores, and radiologic findings berween treatment groups. Differences in cognitive performance were assessed by univaria- 
e F-tests and MANOVA's. Pearson correarions were used

Results

\section{Neurologic assessment}

Nimic of the patients was institutionalised. Threc patients received some external domestic help. Of the 53 eligible patienrs 47 lived with their partner and 6 lived alone. Except for intermittent use of sleep medication, no psychoacrive drugs were used. Three patients used more than four units alcohol on a regular daily basis. Cardiovascular risk factors have been recognised in 17 patients ( $32 \%$ ); 9 patients group 1, 5 patients group 2, and 3 patients group 3 respectively.

All patients had optimal Barrhel scores and were able to perform basic self care. Fifty percent of the parients had an optimal Karnofsky score, the lowest score on the Karnofsky scale was 60 (one parient in group 3). The rating on the Karnofsky scale was frequently more affected by the pulmonary condition than their neurologic condition. More than 50 percent of the patients had an optimal rating on the score of Order, Hellman, and von Essen [18]. Parients of group 1,2, and 3 did not differ significantly with respect to their funcrional status, as measured by the Karnofsky score and the score of Order, Hellman, and von Essen.

Neurologic assessment revealed no abnormalities in 32 (60\%), impairment in 13 (25\%), and slight disability in $8(15 \%)$ parients. Neurologic problems were seen in 5 patients in group $1(24 \%), 8$ patients in group $2(42 \%)$, and 8 patients in group $3(73 \%)$, see fable 2 . The two patients who were not treated with chemotherapy or PCI (age 74 and 80 years, and both with cardiovascular risk factors) suffered hearing loss but were orherwise neurologically normal.

Features of mental impairment included complaints of memory disturbances $(n=14)$, concentration problems $(n=3)$, slight word findings problems $(n=2)$, and calculation problems $(n=1)$. Though mental status and regular neurologic examination revealed no abnormalities, these complaints had quite a great impact on the social funcrioning of some patients; i.e. an accountant resigned because of memory and calculating problems, a busy executive ended his career because his inability to memorise agenda items, a housewife felt uncomfortable not being able to organise her domestic work as before and noticed memory disturbances and slighe word finding problems when she argued with orher people.

Motor abnormalities included discrete hemiparesis $(n=1)$, unstable gait or ataxia $(n=5)$, pyramidal tract signs in the legs in combination with incontinence of urine $(n=2)$. The latcer two parients were both treated with chest irradiarion. One patient with memory disturbances developed visual complaints and an unstable gait; she noticed distortions and discolora tions. MRI of her brain showed white matter lesions righe sided parieto-occipital and a mild cortical atrophy. 


\section{Mental Complaints}

memory disturbances

concentration disturbances

slight dysfasia

dyscalculia

\section{Motor Abnormalities}

discrece hemiparesis

unstable gait

pyramidal tract signs and

urine incontinence

\section{Other}

visual complainrs

Total

symptomatic patients

asymptomatic parients

Table 2. Results of neurologic assessment in 53 long-term small cell lung cancer survivors.

\section{Neuroradiologic assessment}

Cranial CT scanning was performed in 20 patients ( 7 patients group 1,8 patients group 2, and 5 patients group 3) and MR imaging in 21 patients ( 7 parients group 1, 9 parients group 2, 4 patients group 3 , and 1 patient not treated with chemotherapy or PCI). CT and MR scans were evaluated for ventricular enlargement (Evans index), corrical atrophy, comparison of cerebral and cerebellar atrophy, and presence and extent of white matter lesions.
The Evans index was parhologic in one patient only. The extent of cortical atrophy did not differ significantly between groups ( $p=0.3$, Kruskal-Wallis test), sec vable 3. The atrophy of the cerebellum was in proportion with the rest of the cerebrum in most of the patients; judged as less in three and as more in one patient respecrively. White matter lesions were localised as primarily periventricular; aspecific subcortical white matter lesions were seen in only one patient. The predominately periventricular localised white marter lesions were significantly more 


\section{Patients}

$$
\text { group } 1
$$

group 2

group 3

$\mathrm{n}=14$

$\mathrm{n}=17$

$\mathbf{n}=9$

\section{Cortical Atrophy}

none

$1(0 / 1)$

$0(0 / 0)$

mild

$9(4 / 5)$

$12(5 / 7)$

$4(3 / 1)$

moderate/severe

$3(2 / 1)$

$4(3 / 1)$

$5(2 / \#)$

\section{White Matter Lesions}

none

$9(5 / 4)$

$6(4 / 2)$

$1(1 / 0)$

mild

$4(1 / 3)$

$8(2 / 6)$

$4(3 / 1)$

moderate/severe

$1(1 / 0)$

$3(2 / 1)$

$4(1 / 3)$

Table 3. Degree of cortical atrophy and white matter lesions.

Degree of corrical atrophy ( $p<0.3$, Kruskal-Wallis test) and white matter lesions $(p<0.02$, Kruskal-Wallis test) were escablished for different treatment groups; group $1=$ treated with chemotherapy alone; group 2 = treated with prophylactic cranial irradiation after termination of chemotherapy; group $3=$ treated with prophylacric cranial irradiation concurrent or sandwiched with chemorherapy. Rersults are displayed as tocal numbers and specified for imaging technique numbers (CT/MR).

extensive in group 3 than in groups 1 and 2 ( $p=0.02$, Kruskal-Wallis test). see table 3. A cerebral MR scan made in one of the rwo parients who were not treared with chemorherapy or PCI showed mild white matter lesions and moderate cortical atrophy.

Pearson correlations were studied between the extent of white matter lesions and rype of brain imaging technique, age, survival, presence of cardiovascular risks factors, treatment group, number of chemotherapy courses, type of chemotherapy, as well as fraction dose of
PCI. The Pearson correlation matrix $(r>0.3, p<0.05)$ showed a positive correlation with treatment group $3(0.423)$, large number of chemorherapy courses (0.301) and high fraction dose $(0.300)$. There was no significant correlation found with the other factors. 
Patients

group 1

group 2

group 3

controls

p-values

$\mathrm{n}=19$

$\mathrm{n}=19$

$n=11$

$\mathrm{n}=29$

$\mathrm{F}=3.74$

\section{Learning and Memory}

AVLT delta

4.05

4.74

3.45

6.10

0.016

AVLT delayed recal!

6.68

6.00

5.18

10.14

0.000

AVLT delayed recognition

13.05

12.84

12.81

14.10

$0.05-$

Memory Span

AVLT trial 1

4.31

3.73

3.27

5.50

0.000

MST slope score

13.29

10.36

12.20

9.80

0.3 .37

Digit span

4.83

5.09

5.60

5.20

0.274

Speed Information Processing

$\begin{array}{llllll}\text { MST intercept score } & 51.61 & 39.23 & 36.51 & 34.66 & 0.000 \\ \text { CST subtest A } & 53.63 & 55.73 & 55.11 & 29.17 & 0.001 \\ \text { CST subtest B } & 62.88 & 66.94 & 5.3 .11 & 32.82 & 0.000 \\ \text { Stroop subtest A } & 63.00 & 58.41 & (0) .50 & +4.20 & 0.01013 \\ \text { Stroop subrest B } & 76.00 & 68.64 & 69.30 & 57.36 & 0.013\end{array}$

\section{Attention Shifting}

Stroop interference effect

111.08

96.97

194.06

93.57

0.001

CST interferrence effect

28.79

40.51

40.57

63.52

0.116

Table 4. Means of test parameters and p-values of univariate F-tesrs for different trearment groups and matched controls.

Group $1=$ treated with chemotherapy alone; group $2=$ rreared with prophylactic cranial irradiation after termination of chemotherapy; group $3=$ treated with prophylactic cranial irradiation concurrent or sandwiched with chemotherapy. Test parameters were combined in four cognitive domains; AVLT = Auditory Verbal Learning Test; MST = Memory Scanning Test; Stroop = Stroop ColorWord Test; $\operatorname{CST}=$ Concept Shifting Test. High scores mean a good performance for the test parameters AVLT (delta, delayed recall, delayed recognition, and trial 1) and Digit span. Low scores mean a good performance for the other parmeters. 
eparate MANOVA's per cognitive fomain indicated that the mean results of different patient groups of patients were significantly worse than those of matched controls, for each cognitive domain; learning and memory: Wilks' Lambda $=$ $0.634, F(9.175)=4.005, p<.000$; memory span: Wilks' Lambda $=0.685$, $F(9.170)=3.562, p<.000 ;$ speed of information processing: Wilks' Lambda $=$ $0.600, F(15.174)=2.289, p<.006$; and attention shifting: Wilks' Lambda $=$ $0.735, F(6.140)=3.555, \mathrm{p}<.003$. Comparisons of the three patient groups, using MANOVA, however, did not show differences within the four cognitive domains.

The mean scores of the single test parameters and the p-values of univariate $F$ tests are given in table 4 . Univariate $F$ tests revealed significant differences berween parients and controls for most test-parameters. No differences between parients and controls were seen with AVLT delayed recognition, Digir Span, the slope score of the MST and the interference score of the CST.

To evaluate whether treatment variables had an effect on individual cognitive performances, Pearson correlations $(r>0.3$, $p<0.05$ ) were calculated of test-paramerers and type of chemotherapy, number of chemotherapy courses, fraction dose, and cotal dose of PCI. None of these correlations was significant above the $5 \%$ level.
Long-rerm survivors are relatively scarce in neurotoxicity studies as a consequence of the severe prognosis of SCLC. From the results of several neurotoxicity studies, it becomes conceivable thar PCI can induce very serious adverse reactions in combination with chemotherapy in individual SCLC patients [5-9, 13-14, 24-26]. Pedersen et al [4] concluded from the combined data of 8 relatively small retrospective studies with a total of 123 longterm survivors of whom 102 received $P C I$ that $45 \%$ had severe clinical CNS defects. Clinical features of severe CNS injury comprised repeatedly progressive cognitive failure and ataxic gait disturbances [5$9,13-14,24-26]$. Radiologic findings indicated loss of brain rissue $[5-9,13,24-27]$. especially of the periventricular white matter [27-29].

In the present study, the long-term survivors were in relatively good condition, according to different raring scale scores. All patients were ambulatory and capable of self care. In contrast to previous neuroroxicity studies $[5-9,13-14,24-26]$, we did not find seriously disabling CNS toxiciry in long-term survivors, although some neurologie impairment was píesent. Neurologic impairment was found more frequently in more intensively treated parients. Abnormalities concerned predominately complaints about their cognirive functioning, with a considerable effect on the social functioning of some patients. 
As the present study was retrospective, it could be argued that patients with a severe neurologic condition were not able to visit the hospital and therefore could not enter the study. On the other hand, 6 long-term survivors, patients on a regular basis and suffering from severe to less disabling CNS injury caused by cerebrovascular accident $(n=4)$, trauma $(n=1)$, and chronic alcoholism $(n=1)$ participated in the present study. Survival of these 6 patients varied from 3 to 11.5 (mean 6.5) years.

The abnormalities seen on C'T or MR scan did not differ significantly for the different parient groups, with the exception of the severity of white matter lesions. The periventricular white mater lesions have frequently been compared to 'leukoaraiosis' [33], which is commonly seen in the elderly population and presumed to be caused by arteriosclerosis.

Leukoaraiosis is correlated wirh age and cardiovascular risk factors, hypertension in particular [34-35]. Zimmerman et al. [36] found that the radiation induced white matrer lesions had the same aspect on MR scan as the white matter lesions seen in the normal elderly population, which makes the interpretation in our mainly older pacient population difficult.

However, no correlations were found with age or cardiovascular risk factors in the present study. The use of the same rating seale for the extent of the white mater lesions on CT scan and the for the detection of white matter lesions more sensitive MR technique [34-35], may have biased the results.
The white matter lesions are also compared to the 'leukoencephalopathy' described in children who were treated with systemic chemotherapy and a CNS profylaxe [30-31]. Leukoencephalopathy is thought to be the result of direct toxic effects of irradiation or chemorherapy to the neuroglia or indirect ischemic effects to the neuroglia caused by a irradiation or chemotherapy induced microangiopathy, and to be progressive over rime [32]. Many risk factors for the development of neurotoxicity are combined in group 3: $\mathrm{PCl}$ concurrent or sandwiched by chemotherapy, large number of chemotherapy courses, higher fraction doses, and significanc longer survival. Consequently, our CT and MR data do not allow definite conclusions with regard to the white matrer roxicity of PCI. The use of PCI concurrent or sandwiched by chemotherapy has become obsolete at present.

Neuropsychologic assessment revealed no significant differences between the three groups of parients, whereas the cognitive performance of all patient groups was significantly worse when compared with the control group. The type of treatment had no effect on the cognitive impairment at group or individual level. The results suggest that the cognitive impairment of SCLC: patients is more disease related than treatment related. We presumed that emotional distress caused by the knowledge of living with a malignant disease, and diminished physical condicion compromised the cognitive performance of SCICC parients. The findings of the present scudy are in line with results of a 
follow-up study of SCLC patients who underwent serial neuropsychometric testing, before and after various treatments [39].

As mean age and education level of patients are similar in both studies, a comparison of some results of the latter study [39] with present results was valid. It suggested that patients from the present study have slower information processing speeds. Speed of information processing appeared to be a crucial parameter of impairment in several neurologic as well as psychiatric diseases. As the mean survival of patients in the present study was greater than in the follow-up study [39], the lower information processing speed may be caused by additional longterm effects of SCLC or its treatment. We cannor exclude that secondary anxiery or mood disorders amplified the negative impact of the disturbed emotional condition. Neither are we able to determine the influence of progressive white matter lesions, which may represent a late adverse effect of chemotherapy or cranial irradiation [10,27-32]. Laukkanen et al [26] studied 12 long-term survivors, all treared with $\mathrm{PCI}$, and found their performance limited by physical factors in three patients, mild depression in three patients, and significant emorional distress in two patients. Johnson et al [11], who performed a follow-up study of 15 long-term survivors, found a slow progressive decline in neuropsychologic function to be correlated to the extent of cranial CT or MR scan abnormalities. The clinical finding that patients treated with PCI (group 2 and 3 ) complained more about their concentration and memory than patients not treated with PCI (group 1) was unsubstantiared by statisric significance of the psychometric results. The observation that the mean scores on trial 1 of the AVLT of group 2 and 3 were lower than the score of group 1, may account for this apparent inconsistency. Considering the first trial of the AVLT as a word-memory span under interference conditions, which are essential functions in everyday life, the group differences between PCI treated and not treated patients indicated a trend of interference sensitivity difference and may explain why the PCI groups complained more about their cognitive functions. A similar finding was seen in a srudy comparing cognitive profiles of intermitrently solvent-exposed persons with healthy control subjects [20]. The exposed subjects who had strong complaints concerning concentration and attention only had lower scores on trial 1 of the AVLT.

Further clarification for the apparent inconsistency between complaints and psychometric results can be found in the CST interference, which represents an aspect of divided attention. According to Stollery and Flindt [40], intermittently solvent-exposed workers withour memory dysfuncrions showed marked difficulties when attention had to be divided over two competing tasks. In concordance to those findings, scores of the CST interference showed a trend indicating that groups 2 and 3 were slower than group 1 , in the present study. 
Our study differs from previous studies in which CNS injury was heavily attributed to PCI treatment. Though we do not deny the porential hazardous possibilities of PCI, we consider PCI to be one of the facrors capable of disturbing normal CNS functioning. We conclude that the diagnosis SCLC yielded measurable neuropsychologic effects compared to healthy subjects; that more intensively treated patients had relatively more neurologic complaints especially with regard to their cognitive functioning; that the significant longer surviving patients of group 3, who were reated with PCI concurrent or sandwiched by chemotherapy, large number of chemorherapy courses, and higher fraction doses, had more white matter abnormalities; that there was no statistical evidence for additional neurotoxicity of treatment with PCI.

\section{References}

1. Hirsch FR, Hansen HH, Pautson OB: Central nervous system metastases in small cell lung cancer, in Ongerboer de Visser BW, Bosch DA, WoerkomEykenboom WMH (eds): Neuro-Oncology, clinical and experimental aspects: Developments in Oncology (ed 3). The Hague, The Nerherlands, Martinus Nijhoff, 1980, pp 140-166

\section{Nugent JL. Bunn PA Jr, Matthews MJ, et al: CNS} metastases in small cell boonchogenic carcinoma: Increasing frequency and changing pattern with lengthening survival. Cancer 44:1885-1893, 1979

3. Rosen ST, Makuch RW, Lichter AS, et al: Role of prophylactic cranial irradiation in prevention of cenral nervous system metastases in small cell lung cancer: Potential benefit restricted to parients with complete reponse. Am J Med 74:615-624, 1983
4. Pedersen AG, Kristjansen PE, Hansen $\mathrm{HH}$ : Prophylactic eranial irradiation and small cell lung cancer. Cancer Treat Rev 15:85-103, 1988

5. Craig JB, Jackson DV, Moody D, er al: Prospective evaluation of changes in computed cranial tomography in patients with small cell lung carcinoma treated wirh chemorherapy and prophylactic cranial irradiation. J Clin Oncol 2:1151-1156, 1984

\section{Licciardello JT, Cersosimo RJ, Karp DD, et al:}

Disturbing central nervous system complicarions following combination chemorherapy and prophylactic whole-brain irradiation in patients with small cell lung cancer, Cancer Treat Rep 69:1429-1430, 1985

\section{Lee JS, Umsawasdi T, Lee YY, er al:}

Neurotoxicity in long-term survivors of small cell lung cancer. Int J Radiat Oncol Biol Phys 12:313321,1986

\section{Frytak S, Shaw JN, O'Neill BP. et al:}

Leukoencephalopathy in small cell lung cancer patients receiving prophylacric cranial irradiarion. Am J Clin Oncol 12:27-33, 1989

\section{Johnson BE, Becker B, Goff WB 2d, er al:}

Neurologic, neuropsychologic, and computed cranial romography scan abnormalities in 2 to 10 year survivors of small-cell lung cancer. J Clin Oncol 3:1659. 1667, 1985

10. Sheline GE, Wara WM. Smith V: Therapeuric itradiation and brain injury. Int J Radiat Oncol Biol Phys 6:1215-1228, 1980

\section{Johnson BE, Petronas N, Hayes W, et al:}

Neurologic, computed cranial romographic and magneric resonance imaging abnormalities in patients with small-cell lung cancer: Further follow-up of 6to 13-year survivors. J Clin Oncol 8:48-56, 1990

12. Turrisi AT. Brain imadiation and systemic chemotherapy for small-cell lung cancer: Dangerous liaisons? J Clin Oncol 8:196-199, 1990

13. Fleck JF, Einhorn LH, Lauer RC, et al: Is pro- 
phylacric cranial irradiation indicated in small-cell lung cancer? J Clin Oncol 8:209-214, 1990

14. Lishner M, Feld R, Payne DG, et al: Late neurological complications after prophylactic cranial irradiation in patients with small-cell lung cancer: The Toronto experience. J Clin Oncol 8:215-221, 1990

15. Houx PJ, Vreling FW, Jolles J: Age-associated cognitive decline is related to biological life events, in Iqbal K, McLaglin DR, Winblad B, Wisniewski HN (eds): Alzheimers disease: Basic mechanisms, diagnosis and therapeutic strategies. Chichester, United Kingdom, Wiley, 1991, pp 353-358

16. Collin C, Wade DT, Davies S, et al: The Barchel Index: a reliability study. Int Disabil Studies 10:6163,1988

17. Karnofsky DA, Burchenal JH: The clinical evaluation of chemotherapeutic agents in cancer, in Macleod CM (ed): Evaluation of chemotherapeutic agents. New York, NY, Columbia Universiry Press, 1949, pp 199-205

18. Order SE, Hellman S. Von Essen CF, er al: Improvemenr in quality of survival following wholebrain irradiation for brain metastasis. Radiology $91: 149-153,1968$

19. Evans WA: An encephaiographic ratio for estimating ventricular enlargement and cerebral atrophy.

Arch Neurol Psychiatry 47:931-947, 1942

20. Ganzevles PG], Geus BWJ de: Clinical neuropsychological assessment in parienes chronically exposed to organic solvents. Archives of Toxicology $15: 54-57,1992$

21. Lezak MD: Neuropsychological Assessment (ed 2). New York, NY, Oxford University Press, 1983

22. Brand $\mathrm{N}$, Jolles $\mathrm{J}$ : Information processing in depression and anxiety. Psychol Med 17:145-154. 1987 and current controversies. Quart J Exp Psychol 27:132,1975

24. Catane R, Schwade JG, Yarr I,et ai: Follow-up neurological evaluation in parients with small lung carcinoma treated with prophylactic cranial irradiation and chemotherapy. Int J Radiat Oncol Biol Phys 7:105-109, 1981

\section{Chak LY, Zatz LM, Wasserstein P, et al:}

Neurologic dysfunction in patients treated for small cell carcinoma of the lung: a clinical and radiological study. Int J Radiat Oncol Biol Phys 12:385-389, 1986

26. Laukkanen E, Klonoff H, Allan B, et al: The role of prophylactic brain irradiation in limited stage small cell lung cancer: Clinical, neuropsychologic, and CT sequelae. Int J Radiat Oncol Biol Phys 14:1109-1117, 1988

\section{Frytak S, Earnest F 4 th, O'Neill BP, et al:} Magnetic resonance imaging for neurotoxicity in long.rerm survivors of carcinoma. Mayo Clin Proc 60:803-812, 1985

28. So NK, O'Neill BiP, Frytak S, et al: Delayed leukoencephalopathy in survivors wirh small cell lung cancer. Neurology 37:1198-1201, 1987

\section{Lee MY, Nauert C, Glass JP: Treatment-related.} white matcer changes in cancer patients. Cancer $57: 1473-1482,1986$

30. Rubinstein LJ, Hermann MM, Long TF, et at: Disseminated necrotizing leukoencephalopathy: a complication of treated eentral nervous system icukemia and lymphoma. Cancer 35:291-305,1975

31. Price RA, Jamieson PA: The central nervous system in childhood leukemia II. Subacute leukoencephalopathy. Cancer 35: 306-318, 1975.

32. Tsuruda JS, Kortman KE, Bradley WG, et al: Radiation effects on cerebral whire matter: MR evafuation. Am J Roentgenol 149:165-171, 1987

33. Hachinski VC. Potter P, Merskey H: Leuko- 


\section{Awad IA, Spetzler RF, Hodak JA, et al:}

Incidental subcortical lesions identified on magnetic resonance imaging in the elderly. 1. Correlation with age and cerebrovascular risk factors. Stroke 17:10841089, 1986

35. Kertesz A, Black SE, Tokar G, et al:

Periventricular and subcortical hyperintensities on magnetic resonance imaging. 'Rims, caps, and unidentified bright objects.' Arch Neurol 45:404-408, 1988

36. Zimmerman RD, Fleming CA, Lee BC, et al: Periventricular hyperintensity as seen by magnetic resonance: prevalence and significance. AJR Am J Roentgenol 146:443-450, 1986

37. Curran WJ, Hecht-Leavirt C, Schuc L, et al: Magnetic resonance imaging of cranial radiation lesions. Inc J Radiar Oncol Biol Phys 13:1093-1098, 1987

38. Constine LS, Konski A, Ekholm S, et al: Adverse effects of brain irradiation correlated with MR and CT imaging. Ine J Radiat Oncol Biol Phys 15:319330,1988

39. Oosterhout van AG, Boon PJ, Houx PJ, et al: Follow up of cognitive functioning in patients with small cell lung cancer. Ine J Radiat Oncol Biol Phys (in press).

40. Stollery BT, Flindt MLIH: Memory sequelae of solvent intoxication. Scand J Work Environ Health 14:45-48. 1988. 
General discussion 
This study deals with some clinical aspects of brain metastases and its treatment in small cell lung cancer. Brain metastases are the most frequent neurologic complication of small cell lung cancer (SCLC). In a longirudinal follow-up of 203 consecutive patients with SCLC, brain metastases were found in 27 patients (13\%) during the initial staging procedure, and in 52 patients (21\%) during the course of the disease. The cummulative risk of brain metastases reached $47 \%$ for $\mathrm{LD}$ and $69 \%$ for $\mathrm{ED}$ parients, at 2 years from diagnosis. Paraneoplastic syndromes, which are frequently associated with SCLC because of its high neuroendocrine expression, have a much lower occurance. The SIADH (syndrome of inappropriate secretion of anridiureric hormone) was diagnosed in 11 patients $(6.3 \%)$, antibody-medicated parancoplasric syndromes in 5 patients (1.7\%). The frequency of brain metastases was in accordance with data of previous studies; $10 \%$ (range, 0 to $16 \%$ ) at diagnosis of SCLC, $20 \%$ (range, 7 to $30 \%$ ) during therapy, and about $50 \%$ (range, 28 to $64 \%$ ) at autopsy [1-2]. The frequency of paraneoplastic syndromes may be underestimated as only patients with a neurologic presentation were diagnosed and our attention was more or less fixed on central nervous system (CNS) abnormalities. Initial brain metastases responded significantly betrer than delayed brain metastases to symptomatic trearment, in terms of overall survival. Presently, symptomatic treatment of brain metastases consists of chemorherapy and/or radiotherapy. At first, it was believed that the CNS was a relative chemotherapy sancruary as chemotherapy increased survival bur brain metastases became more apparent. Later on, it was recognised that cytotoxic drugs can effectively penetrate into brain metastases. Response rates of $75 \%$ were reported for chemorherapy as well as radiocherapy [4]. Brain metastases have, just as the primary tumor, a high initial response to therapy. In contrast the response of brain metastases to chemotherapy and/or radiocherapy following the first-line treatment of the primary tumor, is much lower and about $43 \%$. As symptomatic treatment of brain metastases is always palliative and when possible, toxicity should be kept to a minimum, it seems to make sense to treat initial brain metastases primarily with chemotherapy and delayed brain metastases primarily with radiotherapy. In case of initial brain metastases, the response to first-line treatment should be evaluated prior to using radiotherapy. The value of consolidarion radiotherapy has yet to be thoroughly investigated. In view of the shortened life expectancy of patients with delayed brain metastases, these patients should primarily be treated with the slightly more effective and less toxic radiotherapy.

The histoparhological subclassification system for SCLC of the International Associarion for the Srudy of Lung Cancer (IASLC) is based upon cell culture work and provided the best interobserver reproductibility thusfar [5-7]. In this study, subtyping was done of histologic as 
well as cyrologic material on which the original SCLC diagnosis was made. However, the frequences of the classic $(85 \%)$ and variant subrypes (together $15 \%)$ were in line with the results of previous studies $[5,6,8]$. The results of the retrospectively done subtyping was correlated to the results of the longitudinal follow-up. Paraneoplastic syndromes were found exclusively in patients with the classic subtype. Statistically this finding represented a trend and needs further study. Nor were significant correlations found between subtypes and metastatic CNS pattern, developing brain metastases, or brain metastatic free survival. The disproportionate distribution of subtypes, and the possible presence of tumor heterogeneity limited the predictive value of the histopathologic subclassification of the IISLC.

The early detection of brain metastases can probably prevent sustained neurologic impairment as the effect of treatment seems to be primarily dependent on how advanced the neurologic symptoms have become when therapy is initiated [9]. In contrast to the use of CT-scan (computed tomography), MRI (magnetic resonance imaging) yielded important addicional information to neurologic examination. With the use of MRI it appeared possible to detect brain metastases in neurologic asymptomatic patients as contrast-enhancing lesions. White matter lesions were also very sensitively demonstrated by MRI. Those focal or confluent, non contrast-enhancing hyperintensities on T2- weighred images represented benign lesions in most of the patients. However, in 2 of 4 neurologic symptomatic patients, those lesions covered brain metastases and parr of them became contrast-enhancing in follow-up MRI. Consequently, in neurologic symptomatic patients with deep white matter on periventricular white matter hyperintensities on T2weighted images, follow-up MRI is recommended as long as the usefulness of a double dose of contrast is unknown. Wherher early derection of brain metastases yields a better response to therapy or just shortens the silent period, is open for discussion.

Delayed brain metastases can represent: seeding from a relapse of the primary tumer, or represent secondary growth of initial micro brain metastases.

Prophylactic eranial irradiation (PCI) was introduced to prevent the secondary growth of micro-rnetastases. In randomized studies, $\mathrm{PCl}$ proved to be effective in disminishing the frequency of brain merastases, from $25 \%$ to $6 \%$, but failed to provide a consistent survival benefit [10]. Brain metastases were presumed to be a sole CNS relapse in up to $10 \%$ of patients, while in the majority of patients the appearance of brain metastases was associated with a relapse of the primary tumor. The efficacy of PCI was studied in limited disease (LD) patients who achieved complete remission (CR) only, because this category of patients could benefit the most from PCI. Patients treated with PCI had a slightly lower number of brain 
metastases, and a significantly longer

brain metastaric free and overall survival than patients not treated with PCI.

These results should be ionterpreted with caution. Only one patient, treated with PCI, had a sole CNS relapse. In all other patients, the appearance of brain metastases can reflect failure of PCI as well as failure of first-line treatment of the primary tumor. PCI was applied non-randomized. Patients treated with PCI had a longer follow-up and received more frequent loco-regional consolidation radiotherapy. Finally, the number of patients was relatively small. We concluded that because of the small parient numbers and the many biasing factors no conclusions should be drawn.

Adverse effects of PCI are normally related to as unexplained CNS abnormalities in long-term survivors of SCLC.

Progressive anacomic changes are documented as white matrer changes and brain atrophy by CT-scanning and MRI. Clinically, these anatomic abnormalities are associated with a wide range of manifestations, varying from mild cognitive deficits to rapid deteriorating dementia syndromes [10-14]. Although it is extremily difficult to attribute these changes to the use of PCI, it is conceivable from the abundant literature on this topic that PCI potentially contributes to the development of CNS toxicity. Many toxifying factors are involved in SCLC and its treament. SCLC, the disease itself, can affect the cognitive performance by paraneoplastic mechanisms or microcoscopic brain metastases. Many of the drugs that are used during treatment of SCLC are potentially neurotoxic, cyrotoxic drugs in particular. When cytotoxic drugs and PCI are used together they can enhance each others CNS toxicity. In SCLC, the use of PCl concurrent or sandwiched by chemotherapy is associated with more and intenser neurotoxicity [10-15].

Of the 18 long-term survivors in our longirudinal follow-up study, the 9 rreated with PCI showed more possible treatment related neurologic and radiologic abnormalities than the remaining 9 not treated with PCI. The possible treatment related effects were relatively mild in most of the parients, probably as a result of treatment with PCI following completion of chemotherapy.

Neuropsychometric follow-up of 32 SCLC parients from diagnosis and during treatment revealed no cognirive dererioration. However, that group of patients scored significantly less than the control group of healthy subjects, who were matched age. gender, and education level. It is possible that the basic cognitive condition of SCLC patients is already compromised at diagnosis by psychologic factors and/or paraneoplastic mechanisms. A poor basic cognitive performance level may have be a contibuting factor to the late neurotoxicity, which is frequently associated solely to PCI. The clinical implications of these findings are difficult to interpret as the tests used are rather aspecific rneasures of cognitive functioning and standard deviarions varied widely. 
An analysis of a large group of long-term survivors of SCLC revealed that the combination of chemotherapy and PCI generated mild neurologic disability and impairment only, in this group of parients which were retrospectively studied. complaints of cognitive dysfunction were heard more frequently from paticnes rrcated with PCI and the most of the patients treated with PC.I concurrent with or sanwiched by chenothcrilpy. 'l'he differences in neurolngic cownitive impairment were not substantiated by neuropsichometric tests. Neuropsychologically, no stutistically significant differcnce wore found between the treatment groups. Nor were correlations found betwen the individual cognitive performance and factors such as age, cardiovascular risk factors, and different treatment modalities. The apparent discrepancy between complaints and neuropsychologic findings was partly explained by a slightly worse score on trial 1 of the AVLT (auditory verbal learning task) and interference of the CST (concept shifting task). The trial 1 of the AVLT represent a memory span under interference conditions, which is an essential function for every day use of memory and concentration. The interference of the CST rewpresent an aspect of divided attention, which is necessary to perform two compering tasks in the same time.

Compared to the results of patients who were neuropsychologically rested at diagnosis and during treatment, long-term survivors had a lower information proce- sing speed. As mean age and education level were similar in both studies the validity of this comparison is justified, and may be indicative of the long-term effects of SCLC or its treatment.

In the group of patients treated with PCI concurent with or sandwiched by chemotherapy, white matter lesions were more common. Leuco-encephalopathy is recognised as a late effect of the combination of chemotherapy and PCI in children, treated for acute leukaemia. The survival of the group of patients, treated with PCI concurent with or sandwiched by chemotherapy, was significantly longer than of the orher groups. The longer survival may account for the difference in white matter lesions.

Another important observation was that all patient groups scored significantly less on the the different neuropsychologic tests than a control group of healthy subjects, who were matched for age, gender, and education level. Again supporting evidence was found for a disease rarher than a treatment effect in CNS toxicity. This stresses the importance of a better understanding of the psychologic and copgnitive functioning of cancer patients. Gross disturbances are easily recognised but discrece disturbances are hardly understood. Nevertheless the fact that discrete cognitive disturbances can have a great impact on every day cognitive functioning. Our limited understanding of the cognitive functions impairs our ability to recognise dysfunctions. 
Neurologic, neuropsychologic, psychologic, and radiologic study results have to be linked for a more concise understanding of cognitive functioning in cancer patients, and of CNS roxicity in SCLC patients in particular.

The clinician dealing with cancer patients needs to be betrer equiped to distinguish berween normal and abnormal cognitive functioning in order to detect neurotoxicity earlier. In individual patients, SCLC and its tretment can generate serious side effects. For a better understanding of the CNS toxicity in SCLC we should not only deal with those serious side effects but be alert to the discrete CNS abnormalities which are manifest in patients but not immmediatly tied to the disease because of their subtility. This holds especiaaly true for SCLC in which the majority of patients already dealing with an extremily bad prognosis lack the disposition to notice subtle dysfunction.

In general, the prognosis, in terms of overall survival and appearance of metastatic neurologic complicarions, is mainly determined by the efficacy of the treatment of the primary tumor. Trearment of the peripheral neurologic complications is predominately symptomaric. The potential benefits and risks of $\mathrm{PCI}$ have been insufficiently researched. The small but not insignificant cure rate in patients with SCLC provide an incentive for further study in the area of long term neurologic complicarions. 


\section{References}

1. Pedersen AG. Diagnosis of CNS metastases from SCLC. In: Lung cancer: Basic and clinical aspects. Boston, MA, Martinus Nijhoff, 1968, pp 153-182.

2. Hirsch FR, Hansen HH, Paulson OB. Central nervous syzstem metastases in small cell lung cancer. In; Ongeboer de Visser BW, Bosch DA, WoerkomEykenboom WMH, eds. Neuro-Oncology clinical and experimental aspects: Developments in oncology, 3. Hague, Martinus Nijhoff, 1980,pp140-166.

\section{Bunn PA Jr, Nugent JL, Matthews MJ. Central} nervous system metastases in small cell bronchogenic carcinomat. Semin Oncol 5: 314-322, 1978.

\section{Kristjansen PG, Hanssen $\mathrm{HH}$ : Brain merastases} from cell lung cancer treated with combination chemotherapy. Eur J Cancer Clin Oncol 24: 545-549, 1988.

\section{Aisner SC, Finkelstein DM, Ettinger DS, et} al: The clinical significance of variant-morphology small cell carcinoma of the lung. J Clin Oncol 8: 402. $408,1990$.

6. Fraire AE, Johnson EH, Yesner R, er al: Prognostic significance of histopathologic subtype and stage in small cell lung cancer. Hum Pathol 23: 520-528, 1992.

\section{Hirsch FR, Matchews MJ. Aisner S, et al:} Histoparhologic classification of small cell lung cancer: changing concepts and terminology. Cancer 62 : 973-977, 1988.

8. Bepler G, Neumann K, Holle R, HavemannK, and Kalbfleisch $\mathrm{H}$ : Clinical relevance of histologic subevping in small cell lung cancer. Cancer 64: 74-79. 1989.

9. Kristensen CA, Kristjansen PEG, Hanssen HH: Systemic chemotherapy of brain metastases from small cell lung cancer: A review. J clin Oncol 10: 1498-1502, 1992.
10. Pedersen AG, Kristjansen PEG, Hansen HH. Prophylactic cranial irradiation and small cell lung cancer. Cancer Treatment Reviews 1988; 15: 85-103

11. Turrisi AT. Brain irradiation and chemotherapy for small-cell lung cancer: dangerous liaisons? J Clin Oncol 8: 196-199, 1990

12. Ihde DC. Prophylactic cranial imadiation: current controversies. Lung Cancer 9 Suppl 1: s69-s74, 1993.

13. Walker RW, Lazar RM, Gralla RJ, Scher HI, Shank B. Neuropsychological abnormalities in long term survivors of small cell lung receiving prophylactic cranial irradiation. Proceedings ASCO 4: C732, 1985.

14. Licciardello, Cersosimo RJ, et al. Disturbing Central Nerous System Complications Following Combinarion Chemorherapy and Prophylactic Whole-brain Irradiation in Patients with Small Cell Lung Cancer. Cancer Treat Rep 69: 1429-1430. 1985

15. Johnson BE. Patronas N, et al. Neurologic, compured cranial tomographic, and magnecic resonance imaging abnormalities in patients with small-cell lung cancer: furrher follow-up of 6- to 13-year survivors. I Clin Oncol 8: 48-56, 1990 
Summary 
Small cell lung cancer (SCLC) is a relatively common lung malignancy and generally has a bad prognosis. This cancer can be accompanied by a wide range of neurologic diseases, ranging from paraneoplastic syndromes to brain metastases. This thesis focuses mainly on the brain metastases related to SCLC.

Chapter 1 comprises a brief general introduction and outlines this thesis' objectives.

Chapter 2 details the results of a longitudinal neurologic follow-up of 203 consecutive parients with SCLC. The most recurring neurologic complication was brain metastasis. A total of 79 parients were diagnosed as having brain metastases, of these 27 had been diagnosed prior to any treatment, and in the remaining 52 the diagnosis was made either during or after trearment of the lung carcinoma. The cumulative risk of developing brain merastasis was $47 \%$ in limited disease patients and $69 \%$ for extensive disease patients. Patienes diagnosed with brain metastases prior to SCLC treatment had a significancly higher survival rate than patients diagnosed wirh brain metastases in later stages of the disease. Histopathologic examination of the brain metastases in 15 patients resulted in a different diagnosis for 2 patients (13\%); orher primary tumor $n=1$, no SCLC after having achieved complete remission for SCLC $n=1$. The discrepancy of the initial histologic diagnosis and that of the brain metastases might be explained by tumor heterogenei- ty, tumor changes influenced by treatment or time, and the development of an other primary tumor in the same patient. The orher neurologic complications of SCLC are briefly described.

Using the guidelines provided by the Parhology Panel of the International Association for the Study of Lung Cancer the predictive value of the histologic subclassification for neurologic complications are discussed in chapter 3 . A retrospective revision was made of the material used to establish the initial SCLC diagnosis of the 239 parients participating in a longitudinal neurologic follow-up study. The subclassification of the histologic as well as cytologic material of these patients resulted in the following: classic cell type $\mathrm{n}=178$, variant cell type $\mathrm{n}=32$ (mixed cell type $n=31$, combined cell type $n=1$ ), and non-classification $n=29$ (only autopsy material available $n=14$, initial diagnosis altered $n=8$, and slides missing $n=7$ ). The relationship between developing brain metastases or the duration of brain metastatic-free intervals and the histologic subtyping did not appear to be of any statistical significance. Those patients suffering neurologic complications of paraneoplastic syndromes all had classic small cell subtype. Not withstanding that this result coincides with the result of the experimental research where classic subtype was characterised by a greater manifestation of neuro-endocrine signs, this finding merely represents a trend. Other non-metastaric complicarions appcared not so much related to the subrype, but 
more so dependant on treatment method or coincidence. The conclusion being that we find no clinical significance for histologic subclassification.

Chapter 4 and 5 continues with a discussion of the validity of using cranial compured- tomography (CT) scan and magneric resonance (MR) imaging in staging patients with SCLC. As part of the initial staging research 57 consecutive patients underwent an examination by a neurooncologist and a cranial CT scan. These patients remained under the controlled supervision of the neuro-oncologist (during the first year quarterly, and biannually there after). A cranial CT scan was repeated if there was any suspicion of brain metastases. Three patients were excluded from the trial for various reasons ( cerebrovascular accident $n=2$, lepromeningeal metastases $n=1$ ). Of the remaining 54 patients, 50 were neurologically asymptomatic and 4 were sympromatic. In 3 patients the use of CT scan showed aberrations symptomatic to brain metastases. The remaining patients showed no signs of possible merastases.

The same trial was carried out in 40 consecutive patients but this time using MR scan. Movement artefacts exiluded 1 patient from this trial. Of the 11 patients in which the MR scan showed deviations similar to metastases 3 were neurologic asymptomatic. The clinical staging of these 3 patients did not change since they already had extensive disease. Of the 14 patients with deep hyperintensive nonGadolinium enhanced white matter lesions, 4 were neurologic symptomatic. Two of these 4 developed brain metastases within 6 months. In the interim, part of the deep hyperintensive nonGadolinium enhanced white matrer lesions became contrase enhanced. We concluded that the CT scan is not superior to neurologic examination for detection of brain metastases in SCLC patients. A MR scan, however, can contribute significantly to the early detection of brain metastases and contribute to the primary staging procedure. Deep white matter hyperintensities can make brain metastases undetectable in neurologically sympromatic parients.

Chapter 6 reports on the effectiveness and safety of prophylactic cranial irradiation (PCI) in a prospectively followed group of 203 consecutive SCLC patients. Of the 37 limited disease patients who had achieved complete remission, brain metastases developed in 3 of 17 treated with PCI, versus 8 of 20 non-PCI treated patients. The number of brain metastases did not differ significantly. Patients who underwent PCI trearment did have al considerably longer brain metastatic-free interval and survival rate. It should be noted that this was a non-randomized study, and that the remaining rreatment course of the SCLC was not totally equal, as well as the fact that the patient population was too small to show any signs of the effects of PCI. Wherher brain metastases developed or nor seemed largely dependant on the behavior of the primary tumor. 
The early as well as the later possible adverse effects of the treatment are covered in detail. Half of the 18 long-term surviving patients had undergone PCI. These patients had a marked increase in cognitive function associated complaints. There was also an increase in cranial CT scan or MR abnormaliries, all of which maybe attributed to PCI treatment. When taken in conjunction with existing literature concerning the use and adverse effects of PCI, it becomes plausible that PCI treatment at least has a synergetic effect on the potential neurotoxic treatment of SCLC. The extent and severity of toxicity to the central nervous system as well as the effectiveness of PCI remains unknown.

Cognitive functioning of SCLC patients is rhe subject matter of chapter 7. In this study 32 consecurive patients underwent neuropsychologic testing, prior to, during, and after treatment with chemotherapy and/or PCI. During the same period these patients were examined neurologically. Patients with brain metastases were excluded from the neuropsychologic follow-up study. The pretrearment average results were compared to those of a control group with similar age, sex, and intelligence quotient. As a result of either brain metastases or premature dearh only 14 patients participated in the second trial session, 11 parients in the third and fourth trial session, and 5 patients in the last session. In patients with no indication of brain metastases neurologic deviations were not present. Less serious complaints of concentration and memory, word finding problems, and libido deficiency were indicated. When compared to the matched control group, the patient group clearly performed worse on the 15 Word Auditory Verbal Learning task, the Stroop color-word test and the Trailmaking test. No further treatment-related negative consequences were established.

We concluded that the disease itself can negatively the patients cognitive funcrioning abilities. Precluding a longitudinal follow-up the effects of the disease and those of the treatment are interchangeable.

Chapter 8 presents the results of research on 59 long-term SCLC survivors. Various long treatment centres in the

Nerherlands were approached and longterm survivors were asked to voluntarily take part in neurologic, neuropsychologic, and neurologic testing. Since the primary objective of the study was to determine the neurotoxicity of the treatment 8 patients were not able to take part for various reasons (cerebrovascular accidents $\mathrm{n}=4$, no chemotherapy or PCI treatment $n=2$, Korsakov syndrome $n=1$, severe head trauma $n=1$ ). The neurologic findings are described in 21 patients treated solely with chemorherapy (group 1), 19 patients treated with $\mathrm{PCI}$ subsequent to chemotherapy (group 2), and 11 patients treated with concurrent or sandwiched $\mathrm{PCl}$ and chemotherapy (group 3). A sratistical comparison is made of the quantifiable neuropsychologic and neuroradiologic data. The neuropsychologic test 
results were compared berween the study groups and also to the results of a healthy group matched for age, gender, and education level. Even though PCI treated parients complained more of cognitive dysfunction and though neurologic abnormalities were more often present in this group of patients (in group 3 more than in group 2), statistically these group differences could not or at best only partially be explained when neuropsychologic and neuroradiologic data were compared.

Among the three patient groups there were no neuropsychologic differences. There was, however, a statistically significant difference with the control group. The statistics for the severity of corrical atrophy and the presence of ventricular enlargement and cerebellar atrophy between the three groups was not representative. Yet parients in group $3 \mathrm{did}$ show meaningful statistic differences where white matter lesions are concerned. Namely they had more white matter lesions than the two other groups.

Patients in group 3 had a significantly longer survival rate. The three patients groups did not differ in age, gender, education lcvel, cardiovascular risk factors or research merhods. The retrospective study of these long-term SCLC survivors concludes that no indications were found for serious PCI related toxicity. The neuropsychologic differences with the healthy control group and the lack of significant disparity among the three patient groups may be indicative of the fact that the patient groups were suffering from SCILC and/or chemorherapy related effects.
The general discussion once again examines the results of all the studies and draws the following conclusions:

- the most frequent neurologic complication of small cell lung cancer are brain metastases.

- the course of the disease when compounded by brain metastases is related to the point when the brain metastases are diagnosed.

- histologic subclassificarion of the International Association for the Study of Lung Cancer is of no significance in predicting neurologic complications.

- in contrast to computed tomography scanning, is magnetic resonance imaging clearly superior to neurologic examination in helping to establish an early diagnosis of brain metastases.

- hyperintensive white matter lesions impede the identification of brain metastases in neurologic sympromatic. patients.

- a longitudinal study is necessary ro adequately derermine the neurocoxicity of the treatment in small cell lung cancer.

- the overall diminished condition of the patients, either due to the disease small cell lung cancer itself or chemotherapy must be taken into consideration when explaining the cognitive dysfunction in long-term survivors of small cell lung cancer

- retrospective study of 59 long-term survivors of small cell lung cancer could not establish indications of frequent and severe prophylactic cranial irradiation related toxicity. 
- subtle cognirive impairment can have a huge impact on daily life funcrioning in long-term small cell lung cancer survivors. - it is important to determine subtle changes in cognitive functioning in order to better understand and eventually prevent central nervous system toxicity associated with small cell lung cancer treatment. 
Samenvatting 
Het kleincellig longcarcinoom is een relatief veel voorkomende longmaligniteit met een over het algemeen slechte prognose. Een wijd spectrum van neurologische aandoeningen, varierend van paraneoplastische syndromen tot hersenmetastasen, kunnen de ziekte compliceren. Dit proefschrift richt zich met name op de hersenmetastasen van her kleincellig longcarcinoom.

In hoofdstuk 1 worden, na een korte algemene inleiding, de doelstelingen van dit proefstuk geformuleerd.

In hoofdstuk 2 worden de resultaten van een longitudinale neurologische follow-up van 203 opeenvolgende patienten met een kleincellig longcarcinoom beschreven. Hersenmetastasen waren de meest frequente neurologische complicatie van de ziekte. In het totaal werden bij 79 parienten hersenmetastasen vastgesteld, in 27 patienten voor behandeling en in de resterende 52 patienten gedurende of na behandeling van het longcarcinoom. Her cummulatieve risico op her krijgen van hersenmetastasen bedroeg $47 \%$ voor de limited disease patienten en $69 \%$ voor de extensive disease patienten. $\mathrm{Na}$ de diagnose van hersenmetastasen was de overleving significant langer van patienten bij wic de hersenmetastasen voor de behandeling van her kleincellig longcarcinoom werden vastgesteld dan van de patienten bij wie de hersenmetastasen pas later in het verloop van de ziekte werden gediagnostiseerd.

Histoparhologisch onderzoek van de her- senmetastasen van 15 parienten leverde in 2 patienten (13\%) een andere diagnose op (andere primaire tumor $n=1$, nietkleincellig longcarcinoom nadat eerder complete remissie was bereikt van een kleincellig longcarcinoom $n=1$ ). Tumor heterogeniteit, veranderingen in de tumor onder invloed van behandeling of tijd en de oncwikkeling van een andere primaire tumor in dezelfde patient zouden de discrepantie tussen de initiele histologische diagnose en die van de hersenmetastasen kunnen verklaren.

Kort worden de overige neurologische complicaties van het kleincellig longcarcinoom beschreven.

\section{In hoofdstuk 3 words de voorspellende} waarde van het optreden van neurologische complicaties besproken van de histologische subclassificarie volgens de richtlijnen van her Parhology Panel van de International Association for the Study of Lung Cancer.

Het materiaal waarop de iniriele diagnose kleincellig longcarcinoom was gesteld van de 239 opeenvolgende patienten, die deelnamen aan een longitudinale neurologische follow-up studie, werd retrospecrief gereviseerd. De subclassificatie van zowel het histologische als het cytologische materiaal van deze patienten leverde de volgende resultaten op: classic cell type $n=178$, variant cell type $n=32$, (mixed cell rype $n=31$, combined cell type $n=1$ ) en geen classificatie $n=29$ (alleen autopsie materiaal $n=14$, initiele diagnose veranderd $n=8$ en coupes verdwenen $n=7$ ). Het histologisch subrype 
bleek niet statistisch significant gerelareerd te zijn aan het krijgen van hersenmetastasen of de duur van hersenmetastase-vrije interval.

Patienten met neurologische complicaties van paraneoplastische syndromen bleken allen het classic small cell subtype te hebben. Alhoewel deze bevinding aansluit bij de resultaten van experimenteel onderzoek waarin het classic subtype zich karakteriseerde door een hogere expressie van neuro-endocriene kenmerken, representeerde deze bevinding statistisch slechts een trend. Andere nier-merastatische complicaties leken niet subtype gerelateerd, doch eerder van de behandeling afhankelijk of op toeval berustend. Concluderend vonden wij geen klinische betekenis voor de histologische subclassificatie.

In hoofdstuk 4 en 5 word nader ingegaan op de waarde van respectievelijk computed tomography (CT) scan en magnetic resonance (MR) imaging van het cerebrum voor de vroeg detectie van hersen metastasen het stadieren van een patient met een kleincellig longcarcinoom. Als onderdecl van het initiele stadieringsonderzoek ondergingen 57 opeenvolgende patienten een onderzoek door een neurooncoloog en een craniele CT scan. Deze patienten bleven onder regelmatige controle van de neuro-oncoloog(eerste jaar elk kwartaal, daarna halfjaarlijks). Bij her vermoeden van hersenmerastasen werd de craniele ("I'scan herhaald. Drie patienten werden van het onderzoek uitgesloten om diverse redenen (cerebrovasculair accident $n=2$, leptomeningeale metastasen $n=1$ ). Neurologisch waren 50 van de overige 54 patienten asymptomatisch en 4 symptomatisch. CT scan leverde bij hersenmetastasen passende afwijkingen op in 3 patienten. In de overige parienten werden geen mogelijk op metastasen berustende afwijkingen gevonden. Met MR scan werd hetzelfde onderzoek herhaald in 40 andere opeenvolgende patienten. Een patient werd wegens bewegingsartefacten uitgesloren van het onderzoek. Van de 11 patienten met op metastasen lijkende afwijkingen op MR scan waren 3 patienten neurologisch asymptomatisch. De klinische stadiering van deze drie patienten veranderde niet ondar zij reeds een extensive disease hadden. Van de 14 patienten met diep in de witte stof gelegen, hyperintense, niet met Gadolineum aankleurende laesies waren 4 patienten neurologisch symptomarisch. Twee van deze 4 patienten kre-gen binnen 6 maanden hersenmetastasen. Een deel van de aanvankelijk nier aankleurende laesies bleek inmiddels veranderd te zijn in aankleurende laesies. Wij concluderen dat CT scan geen meerwaarde heeft boven het neurologisch onderzoek voor de detectie van hersenmetastasen bij patienren met een kleincellig longcarcinoom en derhalve van belang kan zijn voror her initiele stadierings onderzock. MR scan daarentegen kan wel degelijk bijdragen aan de vroegdiagnostiek van hersenmetastasen. Dat de diepgelegen, hyperintense, niet met Gadolineum aankleurende witte stof laesies in neurologisch symptomatische patienten hersenmetastesen kunnen maskeren. 
In hoofdstuk 6 wordt verslag gedaan van de effectiviteit en de veiligheid van profylactische schedel bestraling (PCI) in een groep van 203 opeenvolgende parienten met een kleincellig longcarcinoom, die prospectief werden vervolgd. Van de 37 limited disease parienten, die een complete remissie bereikten, kregen 3 van de 17 met PCI behandelde patienten hersenmetastasen versus 8 van de 20 niet met $\mathrm{PCI}$ behandelde patienten. Het aantal hersenmetastasen verschilde niet statistisch significant. De mer PCI behandelde parienten hadden echter wel een significant langer hersenmetastase-vrij interval en een significant langere overall overleving. Hierbij moet worden aangetekend dat het een niet-gerandomiseerde studie betrof, de overige behandeling van her kleincellig longcarcinoom niet volledig gelijk was en dat de patientengroepen te klein zijn voor het aantonen van een PCI effect. Het wel of niet optreden van hersenmerastasen leek vooral bepaald door het gedrag van de primaire tumor. De vroeg en laat optredende mogelijke bijwerkingen van de behandeling worden in detail beschreven. Van de 18 langdurig overlevende pariencen waren 9 mer PCI behandeld. Mogelijk als gevolg van deze bestraling, presenteerden de met PCI behandelde patienten beduidend meer klachten aangaande hun cognitief funcrioneren en hadden zij vaker een afwijkende craniele CT of MR-scan.

Tesamen mer gegevens uit de literatuur lijkt het aannemelijk dac PCI op zijn minst een synergistisch effect kan hebben op de potentieel neurotoxische behandeling van het kleincellig longcarcinoom. De exacte ernst en frequentie van de centraal zenuwstelsel toxiciteit zijn echter onbekend, evenals de effectiviteit van PCI.

Het cognitieve functioneren van patienten met een kleincellig longcarcinoom is het onderwerp van studie in hoofdstuk 7. Voor deze studie werden 32 opeenvolgende patienten neuropsychologisch onderzocht, voor, gedurende en na behandeling met chemotherapie en profylactische schedel bestraling ( $\mathrm{PCI}$ ). In dezelfde periode werden patienten ook neurologisch onderzocht. Patienten met hersenmetastasen werden van de neuropsychologische follow-up studie uirgesloten. Van de patienten groep werden de gemiddelde resultaten voor behandeling vergeleken met die van een voor leefrijd, geslacht en intelligentie quotient gematchte controle groep gezonde vrijwilligers. Door hersenmetastasen of vroegrijdig overlijden waren voor de tweede onderzoeks sessie 14 , voor de derde en vierde onderzoeks sessie 11 en voor de vijfde onderzoeks sessie 5 patienten beschikbaar. Neurologisch werden geen afwijkingen gevonden in patienten zonder aanwijzingen voor hersenmerastasen. Zowel voor als tijdens behandeling werden lichte klachten over concentratie-, geheugen-, woordvindings- en libido stoornissen geuit. Gemeten met de 15woorden test, de Stroop test en de Trailmaking test presteerden de patienten voor behandeling significant slechter dan de gematchre controle groep. Er werden geen additionele negatieve effecten van de behandeling op het cognitieve functioneren vastgesteld. 
Wij concludeerden dat het cognitieve functioneren van parienten ook door de ziekte zelf negatief kan worden beinvloed. Zonder longitudinale follow-up kunnen de effecten van de ziekte met die van de behandeling verwisseld worden.

In hoofdstuk 8 worden de resultaten weergegeven van een onderzoek naar de centraal zenuwstelsel afwijkingen bij 59 langdurig overlevende parienten met een kleincellig longcarcinoom. In diverse longcentra in Nederland werden langdurig overlevende patienten gevraagd om zich op vrijwillige basis neurologisch, neuropsychologisch en neuroradiologisch te laten onderzoeken. Omdat de studie primair was ontworpen om de neurotoxiciteit van de behandeling van het kleincellig longcarcinoom vast te stellen, werden 8 patienten van het onderzoek uitgesloten om diverse redenen (cerebrovasculair accident $n=4$, geen behandeling met chemotherapie of PCI $n=2$, Korsakov syndroom $n=1$, ernstig schedeltrauma $n=1$ ). De neurologische bevindingen worden beschreven bij 21 alleen met chemorherapie behandelde pariencen (groep 1), 19 met PCI na beeindiging van de chemotherapie behandelde parienten (groep 2) en 11 gelijktijdig of gesandwiched mer PCI en chemotherapie behandelde patienten (groep 3). De gekwantificecrde neuropsychologische en neuroradiologische data worden statistisch vergeleken. De neuropsychologische testresultaten worden zowel onderling als met die van een groep voor leefrijd, geslacht en opleidingsniveau gematchte controlegroep gezonde personen vergeleken.
Alhoewel met PCI behandelde patienten meer klaagden over cognitief dysfunktioneren en bij hen meer neurologische afwijkingen werden geconstateerd (in groep 3 meer dan in groep 2), konden deze groepsverschillen niet of slechts gedeeltelijk statistisch worden bevestigd bij de vergelijking van de neuropsychologische en neuroradiologische data.

Neuropsychologisch verschilden de patientengroepen onderling niet. Wel verschilden alle patientengroepen staristisch significant met de controle groep. De mate van corticale atrofie en het voorkomen van ventrikelverwijding en cerebellaire atrofie verschilden statistisch niet significant tussen de drie groepen patienten. Wel vertoonden patienten van groep 3 statistisch significant meer witte stof laesies dan de andere rwee parientengroepen. Patienten van groep 3 hadden een significant langere overlevingsduur. De patientengroepen verschilden nier qua leefrijd, geslacht, opleidingsniveau, casdiovasculaire risicofaktoren of gebruikte onderzoekstechnieken.

Wij concludeerden dat in het retrospecrieve onderzoek van deze langdurig overlevende patienten met een kleincellig longearcinoom geen aanwijzingen werden gevonden voor her frequent voorkomen van een ernstige PCI gerelateerde toxiciteit. Het ontbreken van duidelijke groepsverschillen en het significante verschil met de controlegroep neuropsychologisch, doet eerder een ziekte- en/of chemotherapie effect vermoeden.

In de algemene discussie wordt nog eens 
In de algemene discussie wordt nog eens ingegaan op de resultaten van alle onderzoeken en worden de volgende conclusies getrokken:

- hersenmetastasen zijn de meest frequente neurologische complicatie van her kleincellig longcarcinoom.

- het beloop van de door hersenmetastasen gecompliceerde ziekten is mede afhankelijk van het tijdstip waarop de hersenmetastasen worden gediagnosticeerd. - voor het voorspellen van neurologische complicaties heeft de histologische subclassificatie van de International Association for the Study of Lung Cancer geen betekenis.

- voor de vroegdiagnostiek van hersenmerastasen heeft magnetic resonance imaging in tegenstelling tor computer tomography een meerwaarde boven neurologisch onderzoek.

- in neurologisch symptomatische parienten vormen de diep gelegen hyperintense wirte stof laesies een beletsel voor de vroegderectie van hersenmetastasen.

- voor het adequaat vaststellen van de neurotoxiciteit van de behandeling van het kleincellig longearcinoom is een longitudinale studie noodzakelijk.

- bij de verklaring van de cognitieve problemen, die kunnen worden aangetroffem bij langdurig overlevende patienten, moet rekening worden gehouden mer een door de ziekte en chemotherapie verminderde algehele conditie van de parient.

- retrospectief onderzoek van 59 langdurig overlevende patienten met een kleincellig longcarcinoom bracht geen aanwijzingen voor het bestaan van ernstige aan profylactische schedelbestraling gerelateerde toxiciteit.

- subriele cognitieve problemen kunnen een grote impact hebben op her dagelijks funktioneren van langdurig overlevende patienten met een kleincellig longcarcinoom.

- voor een beter begrip en eventuele preventie van de centraal zenuwstelsel toxicireit van de behandeling van het kleincellig Jongcarcinoom is het van belang om een achteruitgang in het cognitieve funktioneren vroeg vast te stellen. 


\section{Dankwoord}

Bij de tot stand komen van dit proefschrift waren veel mensen direct of indirect betrokken. Al deze mensen ben ik zeer erkentelijk voor de prettige en vruchtbare samenwerking.

De promorores, Prof. Dr. Geert Blijham voor zijn opbouwende kritick en Prof. Dr. Jaap Troost voor de eenvoudige oplossingen van ingewikkeld lijkende problemen.

De copromoter, Dr. Albert Twijnstra die me in de gelegenheid stelde om te werken met de door hem in de loop van vele jaren verzamelde patienten gegevens. Hierdoor werd ik niet alleen in staat gesteld om klinisch wetenschappelijk onderzoek te doen doch kreeg ik ook de gelegenheid om serieus kennis te maken met de neuro-oncologie. Voor klinisch werenschappelijk onderzoek en voor neuro-oncologie is mijn enthousiasme gegroeid.

Mijn collega-onderzoekster, Marjan van de Pol. Zij was verantwoordelijk voor het vergaren en beheren van een belangrijk deel van de data van de parienten in her Academisch Ziekenhuis in Maastricht. Haar nier aflarende ijver en inzer vormen de fundamenten van dit proefschrift.

Diverse vakspecialisten, waarmee bij de uitwerking van de verschillende onderzoeksprojecten intensief werd samengewerkt: Dr. Guul ten Velde (longziekten); Dr. Eric Thunnissen (parhologische anatomie); Dr. Alex Volovics (statistiek); Drs. Peter Boon, Dr. Perer Houx, Dr. Paul Ganzevles, Drs. Bianca de Geus, Drs. Rianne van Vonderen (neuropsychologie); Prof. Dr. Jan Wilmink (neuro-radiologie). Zonder het geduld en de inbreng van deze mensen was het proefschrift niet geworden tot wat het nu is.

De longartsen, Prof. Dr. Piet Postmus, Dr. Mia Coolen, Dr. P. Oostinga, Dr. J. Festen, Dr. L.Willems, Dr. W. Bakker, Dr. P. Baas, Dr. J. van den Beukel, Dr. J. Klein, Dr. P. van de Valk, Dr. F. Maassen, Dr. J. van Noord, Dr. M. Tjwa en Dr. B. Drenth, die de praktische uitvoering van het landelijk onderzoek naar de neurotoxiciteit van de behandeling van het kleincellig longcarcinoom hebben mogelijk gemaakt. Zij vroegen hun langdurig overlevende parienten om deel te nemen aan het onderzock en boden ons gastrrij de ruimte en de mogelijkheden om de patienten op lokatie te onderzoeken. 
De vele patienten, die bereid waren mee te werken aan het onderzoek. Veel van hen overwonnen de angst om zich voor de zoveelste keer in het ziekenhuis te laten onderzoeken. $\mathrm{Zij}$ investeerden veel tijd en energie om de talrijke onderzoeken tot een goed einde te brengen.

Prof. Dr. Sj. Sc. Wagenaar, voor zijn kritische bijdrage aan mijn proefschrift.

De stafleden en de assistenten van de afdeling neurologie in het De Wever Ziekenhuis, die me de mogelijkheden en ruimte gaven om het onderzoek tot een goed einde te brengen.

De bibliothecaressen in het De Wever Ziekenhuis, Miriam Wetzels en Romy Clignet, die me behulpzaam waren bij het opzoeken van de literatuur, accuraat de referenties corrigeerden en me tussendoor ongevraagd ook van meer algemene levenswijsheden voorzagen.

Miriam Arango, mijn vertaalster en kameraad, die het onderzock internationaal toegankelijk maakte. En mij. gedurende televisie- en radio-loze tijden, voorzag van het belangrijkste wereld nieuws.

Theo Mady, die ik niet alleen waardeer vanwege zijn kwaliteiten als fotograaf en vormgever, maar ook vanwege zijn muziek kennis.

Marianne, mijn vrouw, voor de liefde en steun die onontbeerlijk waren voor her volbrengen van deze soms bar ongezellige taak. 


\section{Curriculum vitae}

Ansel van Oosterhout werd op 15 juni 1961 geboren in Delft. Zijn jeugd bracht hij door in Mook. In 1979 haade hij het eindexamen Arheneum-b aan het Elshofcollege in Nijmegen en in 1986 het arts-examen aan de Katholicke Universiteit in Nijmegen. Aansluitend vervulde hij zijn militaire dienstplicht als arts op de afdeling neurologie van het Militair Hospitaal in Utrecht onder supervisie van Dr. W.E. Vliegenthart. Van 1988 tot heden is hij als arts-assistent verbonden aan de afdeling neurologie van het De Wever Ziekenhuis in Heerlen (opleider Dr. C.L. Franke). In het Academisch Ziekenhuis Maastricht volgde hij een stage neuro-oncologie (Dr. A Twijnstra) en psychiatric (Prof. Dr. H. van Praag en Prof Dr. G. van Leeuwen). In het De Wever Ziekenhuis in Heerlen werd in oktober 1994 de aantekening klinisch neurofysiologie. behaald (opleider Dr. J.W. Vredeveld). Momentecl volgt hij een stage neurochirurgie in het Klinikum in Aken (Prof. Dr. J. Gilsbach). 